\title{
\begin{tabular}{l|l} 
Mibraries & DSpace@MIT
\end{tabular}
}

\author{
MIT Open Access Articles
}

\section{Policy Preferences and Policy Change: Dynamic Responsiveness in the American States, 1936-2014}

The MIT Faculty has made this article openly available. Please share how this access benefits you. Your story matters.

Citation: Caughey, Devin, and Christopher Warshaw. “Policy Preferences and Policy Change: Dynamic Responsiveness in the American States, 1936-2014." American Political Science Review 112, 2 (November 2017): 249-266 (C) 2017 American Political Science Association 2017

As Published: http://dx.doi.org/10.1017/S0003055417000533

Publisher: Cambridge University Press (CUP)

Persistent URL: http://hdl.handle.net/1721.1/118850

Version: Author's final manuscript: final author's manuscript post peer review, without publisher's formatting or copy editing

Terms of use: Creative Commons Attribution-Noncommercial-Share Alike 


\title{
Policy Preferences and Policy Change: Dynamic Responsiveness in the American States, 1936-2014
}

\author{
Devin Caughey* \\ MIT
}

\author{
Christopher Warshaw ${ }^{\dagger}$ \\ MIT
}

\begin{abstract}
In a democracy, government policies should not just be correlated with citizens' preferences, but also respond dynamically to them. Using eight decades of data, we examine the magnitude, mechanisms, and moderators of dynamic responsiveness in the American states. We show that on both economic and (especially) social issues, the liberalism of state publics predicts future change in state policy liberalism. Dynamic responsiveness is gradual, however; large policy shifts are the result of the cumulation of incremental responsiveness over many years. Partisan control of government mediates only a fraction of responsiveness, suggesting that, contrary to conventional wisdom, responsiveness occurs mainly through the adaptation of incumbent officials. Dynamic responsiveness has increased over time but does not seem to be influenced by institutions such as direct democracy or campaign finance regulations. We conclude that our findings, though in some respects normatively ambiguous, on the whole paint a reassuring portrait of statehouse democracy.
\end{abstract}

We thank Jeffrey Lax, Seth Hill, seminar participants at Columbia University, Washington University-St. Louis, Texas A\&M, Georgetown University, George Washington University, and Princeton University, and panelists at the 2014 American Political Science Association Conference and 2016 State Politics Conference for feedback on previous versions of this manuscript. We appreciate the excellent research assistance of Melissa Meek, James Dunham, Robert Pressel, Meg Goldberg, Kelly Alexander, Aneesh Anand, Tiffany Chung, Emma Frank, Joseff Kolman, Mathew Peterson, Steve Powell, Charlotte Swasey, Lauren Ullmann, and Amy Wickett. We also appreciate the willingness of Carl Klarner to generously share data. We are grateful for research support from the Dean of the School of Humanities, Arts, and Social Sciences at MIT. All mistakes, however, are our own.

${ }^{*}$ Associate Professor, Department of Political Science, Massachusetts Institute of Technology, 77 Massachusetts Ave., Cambridge MA 02139-4301, caughey@mit.edu, 703-999-8822. Corresponding author.

${ }^{\dagger}$ Associate Professor, Department of Political Science, Massachusetts Institute of Technology, 77 Massachusetts Ave., Cambridge MA 02139-4301, cwarshaw@mit.edu, 617-733-4991. 


\title{
Policy Preferences and Policy Change: \\ Dynamic Responsiveness in the \\ American States, 1936-2014
}

\begin{abstract}
In a democracy, government policies should not just be correlated with citizens' preferences, but also respond dynamically to them. Using eight decades of data, we examine the magnitude, mechanisms, and moderators of dynamic responsiveness in the American states. We show that on both economic and (especially) social issues, the liberalism of state publics predicts future changes in state policy liberalism. Dynamic responsiveness is gradual, however; large policy shifts are the result of the cumulation of incremental responsiveness over many years. Partisan control of government mediates only a fraction of responsiveness, suggesting that, contrary to conventional wisdom, responsiveness occurs mainly through the adaptation of incumbent officials. Dynamic responsiveness has increased over time but does not seem to be influenced by institutions such as direct democracy or campaign finance regulations. We conclude that our findings, though in some respects normatively ambiguous, on the whole paint a reassuring portrait of statehouse democracy.
\end{abstract}


What drives policy change? The full answer is surely complex, involving among other things turnover in government personnel, the emergence of new policy problems, and the availability of potential solutions (e.g., Kingdon 1995). But in a democracy, policy change should also be driven by citizens' policy preferences: elected officials should respond to public opinion by moving policy in its direction. Dynamic responsiveness of this kind can be thought of as a minimal standard for democratic representation. If policy change has no empirical relationship with mass preferences, then it is unlikely that citizens exercise the kind of control over government that lies at the core of democratic theory. ${ }^{1}$

Dynamic responsiveness has been documented primarily at the national level, especially in the United States but also in Canada and the United Kingdom. National policymaking has been shown to respond both to policy-specific changes in mass opinion (Page and Shapiro 1983) and to the public's overall "policy mood" - its global preference for more or less government activity (Stimson, MacKuen, and Erikson 1995; Soroka and Wlezien 2010). Moreover, responsiveness to public mood has been found to operate through two main channels: partisan selection (the election of candidates of one partisan type rather than another) and adaptation (driven primarily by elected officials' anticipation of voter sanctions). While the dynamic responsiveness literature leaves plenty of room for policy determinants other than public opinion, the seemingly robust relationship between mass preferences and policy change offers reassuring evidence of citizens' influence over government policies.

These optimistic conclusions, however, have been subject to trenchant critiques. Achen and Bartels $(2016$, 45-6), for example, argue that the impact of adaptation pales relative to the effect of partisan control of government offices. They thus conclude that "citizens affect public policy — insofar as they affect it at all — almost entirely by voting out one partisan team and replacing it with another," that is, through partisan selection. Indeed, notwithstanding the contrary arguments of Stimson, MacKuen, and Erikson (1995), the prevailing scholarly

1. We use the term dynamic responsiveness instead of dynamic representation (Stimson, MacKuen, and Erikson 1995) in order to distinguish responsiveness from alternative measures of representation, such as proximity or congruence (Achen 1978). Responsiveness is often considered the hallmark of democracy (Dahl 1971), though it is not by itself a sufficient condition. For other necessary conditions, see, e.g., Dahl (1989). 
view is that partisan selection dominates adaptation as a mechanism of responsiveness in the United States - and in recent decades, increasingly so (Levitt 1996; Ansolabehere, Snyder, and Stewart 2001; Lee, Moretti, and Butler 2004; Poole 2007; Fowler and Hall, Forthcoming). This has in turn raised normative concerns about "leapfrog representation" by partisan extremists, whose actions may be responsive to, but are rarely congruent with, the preferences of the relatively moderate public (Bafumi and Herron 2010; see also Poole and Rosenthal 1984; Lax and Phillips 2012).

To some degree, these divergent conclusions stem from differences in research design. Most studies that emphasize ideological adaptation examine how policymaking responds to mass opinion in a single country over time (e.g., Stimson, MacKuen, and Erikson 1995; Soroka and Wlezien 2010; but see Kousser, Lewis, and Masket 2007). By contrast, work that stresses the dominance of partisan selection is overwhelmingly cross-sectional, typically examining roll-call voting in a single legislature. ${ }^{2}$ Each approach has its advantages and limitations. Time-series studies have the advantage of being explicitly dynamic in orientation and also of focusing on government policies, which are arguably the ultimate metric of representation. But due to the inherent limitations of time-series analysis (small samples, model dependence, etc.), the results of within-country studies tend to be somewhat fragile. For their part, cross-sectional studies tend to have large sample sizes and often employ stronger identification strategies, such as regression-discontinuity (RD) designs. But they too are limited by their focus on within-legislature variation in roll-call voting or other forms of position-taking, which means that they cannot detect governments' collective responsiveness to popular preferences (Weissberg 1978).

The U.S. states offer potentially fertile ground for overcoming these limitations. By examining fifty states over many years, we can employ combined time-series-cross-sectional (TSCS) analyses that avoid many of the pitfalls of either approach on its own. Moreover, by using state policies as the outcome of interest, we can explore how public opinion influences

2. For instance, even though the data used by Ansolabehere, Snyder, and Stewart (2001) cover many decades, their analysis essentially consists of a sequence of cross-sectional regressions. 
not only the positions politicians take, but what governments actually do. A further advantage of state politics is that variation across states provides a natural point of comparison or benchmark for assessing the substantive magnitude of dynamic responsiveness.

Notwithstanding the methodological attractions, U.S. states present something of a hard case for dynamic responsiveness. Due to fiscal federalism and other constraints on state governments, structural and economic conditions may dominate public opinion as determinants of state policies (Oates 1972; see also Dye 1966). Moreover, the lower salience of state politics and increasing nationalization of elections mean that state elections are powerfully affected by national tides, undermining the direct accountability relationship between state-level officials and their electorates (Rogers 2016; Hopkins 2016). Thus, despite the "awesome" cross-sectional association between the liberalism of state policies and publics (Erikson, Wright, and McIver 1993; see also Gray et al. 2004; Lax and Phillips 2012), public opinion may be only one relatively minor causal factor among the many that explain change in state policies (see Ringquist and Garand 1999). Finally, studying dynamic responsiveness in the states presents formidable measurement challenges, for doing so requires yearly summaries of policy outputs and public preferences in each state over many decades.

Fortunately, recent methodological advances have made such an analysis possible. Using newly developed models for estimating the ideological orientation of state publics, we construct dynamic measures of mass and government policy liberalism in each year between 1936 and 2014. The mass liberalism scores, estimated separately for economic and social issue domains, are based on a dataset of approximately 1.5 million individuals' responses to over 300 domestic policy questions. From the same dataset, we also derive analogous time series of party identification (PID) in each state-year. The government policy liberalism scores, also estimated separately for economic and social policies, are based on an annual dataset of nearly 150 continuous and categorical state policies. Combining these measures with data on party control of state offices, we use a series of dynamic panel models to examine state-level dynamic responsiveness as well as its mediators and moderators. 
Our analyses reveal that on both economic and (especially) social issues, the policy liberalism of state publics is a robust predictor of future changes in the liberalism of state policies. In other words, when a state's citizens are comparatively liberal, its policies tend to become more liberal relative to other states. Dynamic responsiveness is gradual, however. Large policy shifts are the result of the cumulation of incremental responsiveness over many years. Mass liberalism also predicts the election of more Democratic officials, though less strongly than does the state-level balance of mass PID. Democratic control of state government in turn leads to more liberal policies, suggesting that partisan selection does indeed mediate dynamic responsiveness. But we also find that policy reacts directly to citizen liberalism, holding constant the party that controls the government. This suggests that adaptation is an important, and perhaps dominant, mechanism of dynamic responsiveness.

In addition to examining the mediators of the opinion-policy relationship, we also investigate what factors moderate this relationship. Our most robust finding is that dynamic responsiveness has increased over time, on both social and economic issues. We find that the cross-sectional relationship between opinion and policy has always been stronger outside the South, and we find some evidence of differential dynamic responsiveness between regions as well, though primarily in recent decades. We also consider various laws and institutions thought to influence representation-including suffrage restrictions, campaign contribution limits, direct democracy, and legislative professionalism - but find no reliable evidence that they moderate dynamic responsiveness.

We close our paper with a discussion of the normative implications of our findings. This is a difficult issue, for dynamic responsiveness is but one indicator of the quality of representation, and under some circumstances an increase in responsiveness may even degrade other indicators, such as proximity or congruence (Achen 1978; Matsusaka 2001; Bafumi and Herron 2010; Lax and Phillips 2012). We conclude, however, that our findings are on the whole normatively positive. In addition to being powerfully related to citizen policy liberalism at any point in time, state policy liberalism is also responsive on the margin to shifts in 
public preferences. Given the many reasons for doubting the existence of policy voting and responsiveness (Achen and Bartels 2016) - reasons that are if anything more compelling at the state than the national level - the mere existence of state-level dynamic responsiveness is reassuring. On the other hand, contrary to many cross-sectional studies (e.g., Lax and Phillips 2012), we find little indication that policy liberalism is over-responsive to citizen preferences. Rather, within-state differences in citizen preferences lead to changes in policy liberalism that are small relative to the differences across states.

\section{Theoretical Framework}

As a theoretical framework for our analysis, we sketch a dynamic model of representation, building on the work of Achen (1978) and others. In our framework, ideological variation is assumed to be one-dimensional within a given policy domain. We presume that governments respond on the margin to mass preferences, making policy more liberal when the public moves left and more conservative when it moves right. Such responsiveness does not imply, however, that policies are necessarily congruent with mass preferences. Rather, due to factors ranging from state governments' resource constraints to inequality of policy influence across citizens, policies may be systematically biased relative to what the average citizen desires. Nor is responsiveness necessarily proportionate; governments may respond by moving policy less than the public desires, or alternatively they may over-react to public opinion and oscillate between extreme policy positions.

Furthermore, in our model — and here we depart from cross-sectional models like Achen'sresponsiveness need not be immediate. This acknowledges the numerous sources of statusquo bias in policymaking, including the prevalence of budgetary incrementalism, the veto power of pivotal legislators, limited space on the political agenda, and incumbents' insulation from mid-term removal. Together, these barriers conspire to make it difficult to overturn existing policies. Thus, even if elected officials are perfectly representative, they will often be 
unable to bring all policies immediately in line with new configurations of mass preferences. Rather, a sudden one-time change in mass liberalism will be incorporated incrementally into policy liberalism, as in each year the state updates a portion of its policies. Eventually, if mass opinion remains stable, this model predicts that the state will reach a new policy equilibrium that reflects both the influence of the mass public and the persistent sources of policymaking bias in that state. In short, a dynamic model of representations implies that responsiveness should be incremental, with modest short-term effects potentially cumulating into large long-run differences. ${ }^{3}$

\subsection{Mechanisms}

In a representative democracy, there are two main mechanisms by which mass publics can influence policymaking, which we refer to as selection and adaptation (compare Miller and Stokes 1963; Stimson, MacKuen, and Erikson 1995; Fearon 1999). In the selection mechanism, citizens influence government policymaking by electing candidates whose ideological type best represents their views. In the contemporary American two-party system, this generally entails choosing between Democrats and Republicans - that is, partisan selection. For partisan selection to be an effective channel for responsiveness, a two-step process is required. First, mass liberalism must affect which party wins elections. Second, the partisan outcome of elections must affect policy liberalism. Partisan selection is thus the part of mass liberalism's effect on policy that is mediated by party control of government offices.

Adaptation, by contrast, is the portion of responsiveness not mediated by party controlthat is, with party control held constant. Most theoretical work on adaptation has focused on individual incumbents' incentives to preempt electoral sanctions by responding preemptively to public sentiment (Downs 1957; Mayhew 1974; Kingdon 1989; Snyder and Ting 2003). In

3. It should be noted that our model of dynamic responsiveness differs from those of Stimson, MacKuen, and Erikson (1995) and Soroka and Wlezien (2010) in that we define mass liberalism as a measure of absolute preference. They, by contrast, conceptualize policy "mood" as a preference for policy change - that is, for more or less government than is currently being provided (see Stimson 1991). Their model thus implies that mood, being partly a function of current policy, should respond "thermostatically" to policy changes, whereas no such negative feedback loop is implied by our model. 
principle, such individual-level adaptation can result in perfect responsiveness without the replacement of a single incumbent (and thus without any change in party control). As defined here, however, adaptation also encompasses within-party turnover: the replacement of moderate incumbents with more extreme members of the same party, or vice versa.

On the whole, the empirical literature on responsiveness emphasizes the dominance of selection over adaptation (Levitt 1996; Ansolabehere, Snyder, and Stewart 2001; Lee, Moretti, and Butler 2004; Poole 2007; but see Stimson, MacKuen, and Erikson 1995; Kousser, Lewis, and Masket 2007). There is certainly ample evidence for the second step in the selection mechanism, partisan effects on policy. At the state level, for example, electing Democrats rather than Republicans leads to much more liberal legislative representation and to modestly more liberal state policies (Shor and McCarty 2011; Caughey, Warshaw, and Xu, Forthcoming; Fowler and Hall, Forthcoming; Caughey, Tausanovitch, and Warshaw 2017). In the legislature, partisan effects on policy seem to be driven predominantly by shifts in majority control, the size of the majority having little independent effect on policy (Caughey, Warshaw, and $\mathrm{Xu}$, Forthcoming). The evidence for the first step - mass liberalism's effect on elections - is less robust, especially in studies of dynamic responsiveness. Achen and Bartels, for example, stress the fragility and model-dependence of the evidence for partisan selection in national politics, leading them to conclude that mass policy preferences "are of relatively little importance in determining who wins" elections (Achen and Bartels 2016, 46). Though there is less empirical work on the subject, the dynamic relationship between mass liberalism and election outcomes is likely to be even weaker in the states, where electoral shifts are dominated by exogenous national conditions (Rogers 2016). In short, notwithstanding the evidence for party effects, it is unclear how much of state policy responsiveness is mediated through party control.

On the other hand, there is reason to believe that adaptation is a more important mechanism of state policy responsiveness than the existing literature suggests. Most existing studies focus on roll-call voting in a single legislature, which means that they cannot mea- 
sure collective responsiveness to public opinion. Thus, if a state public moves to the right and all officials respond equally to this shift, a comparison of state legislators' roll-call votes will not detect any adaptation, only cross-sectional ideological differences between legislators. ${ }^{4}$ The relatively few studies that examine opinion effects on policy rather than roll calls, whether in cross section (Erikson, Wright, and McIver 1993) or time series (Erikson, MacKuen, and Stimson 2002), tend to find greater evidence for responsiveness unmediated by party control. In sum, we expect adaptation to be a more important mechanism of state policy responsiveness than the more general literature on responsiveness suggests.

\subsection{Variation Across Issue Domains}

Nearly all studies that have found strong evidence of state-level policy responsiveness either employ general measures of liberalism-conservatism that combine different policy domains (e.g., Erikson, Wright, and McIver 1993) or else focus almost exclusively on social policies (e.g., Lax and Phillips 2009, 2012). What evidence there is for responsiveness on economic issues tends to be somewhat weaker (Pacheco 2013). ${ }^{5}$ This is not surprising, for there are several reasons to expect states to be less responsive on economic than social issues.

First, states tend to have less policymaking discretion on economic issues. Federal and state governments share responsibility over many policy areas, and a large share of state government monies come from the federal government (Pew Charitable Trusts 2016), which is largely unresponsive to shifts in state-level public opinion. State taxing and spending choices are also constrained by economic competition with other jurisdictions. Thus, regardless of their citizens' preferences, states can increase taxes and regulations only so much before businesses and higher-income citizens vote with their feet by moving to other states (Oates 1972; Bailey and Rom 2004).

4. This is true unless the scaling bridges legislators' ideal points across time using comparable roll-call votes, which is rarely done (for an exception, see Bailey 2007).

5. In her study of state welfare and education spending, Pacheco $(2013,319)$ notes that "conclusions regarding dynamic policy representation [i.e., responsiveness] vary depending on model specification" and are not robust to the inclusion of year fixed effects. 
Economic and social issues differ at the mass level as well. Because social policies tend to be more symbolic than technical and to concern ends rather than means, they are more likely than economic policies to be "easy" issues for citizens. Citizens are thus likely to find it easier to "calculate relative positioning of parties and candidates" on social issues (Carmines and Stimson 1980, 82). Citizens' policy preferences on social issues are also likely to be more stable and coherent than their economic preferences, making it easier for politicians to discern signal from noise in public opinion. ${ }^{6}$ In short, because social policies are both more amenable to state control and easier for citizens to understand, we should expect state-level responsiveness to be stronger on social than economic issues.

\subsection{Institutional Moderators}

In addition to varying across issue domains, dynamic responsiveness may also vary across institutional and other contexts. Indeed, as Lax and Phillips (2012, 158) note, "many of the largest debates in the state politics literature involve which, if any, institutional features of state government enhance or undercut the relationship between policy and opinion." We explore this possibility by examining four sets of institutions that might moderate state policy responsiveness.

The past eight decades have witnessed large changes in the institutional structure of American democracy, none more important than the 1960s-era dismantlement of suffrage restrictions, mainly in Southern states (Key 1949; Mickey 2015). These restrictions both changed the demographic and ideological composition of the electorate and reduced voter turnout overall (J. M. Kousser 1974; Springer 2014). As a result, one might hope and expect that the elimination of undemocratic institutions in the South led to greater responsiveness to citizens' policy preferences in those states. On the other hand, there is recent evidence to suggest that the one-party South was not obviously less responsive to the eligible electorate than the two-party North (Caughey 2016). Since the preferences of different social groups

6. See Przeworski, Stokes, and Manin (1999, 8-9) on responsiveness as the relationship between signals (expressions of public preferences) and policies (authoritative government decisions). 
tend to move in parallel with one another (Page and Shapiro 1992), this means that dynamic responsiveness to one group often implies responsiveness to the public as a whole (Stimson 2009). To the extent that this is true, then the elimination of suffrage-restricting institutions may not have had a substantial effect on dynamic responsiveness in the South.

There are also reasons to believe that campaign contribution limitations may influence policy responsiveness by affecting politicians' incentives to focus on the preferences of the median voter. Indeed, contributions from corporations and wealthy individuals could incentivize elected officials to focus more on their opinions than the opinion of the median voter (Bartels 2008; Gilens 2012). We therefore expect limits on campaign contributions to increase the responsiveness of policy to public opinion. Several previous studies have examined the direct effect of campaign finance limits on state legislators' ideology (Barber 2016; La Raja and Schaffner 2015) and state policy (Besley and Case 2003; Werner and Coleman 2013), but no previous study has examined the effect of campaign finance rules on the responsiveness of state policies to public opinion.

Another set of institutions that possibly improve responsiveness are reforms designed to enhance what might be called citizen governance, such as direct democracy and term limits. Direct democracy might do so by giving citizens the ability to circumvent elected officials and enact their preferred policy through the ballot box (Matsusaka 2008). In addition, the threat of the initiative may lead elected officials to change their behavior in order to preempt future ballot measures (Gerber 1996). Finally, even if elected officials do not actively seek to preempt future initiatives, the results of initiatives may help them learn about voter preferences (Matsusaka 2008). Despite sound theoretical reasons to expect that direct democracy might improve responsiveness, empirical studies of its effects have been ambiguous. ${ }^{7}$

Term limits might increase responsiveness by inducing greater turnover among legislators. This could lead to the election of legislators who better reflect constituents' (current) prefer-

7. Some studies find that direct democracy enhances responsiveness, at least in some policy areas (Arceneaux 2002; Gerber 1996; Matsusaka 2010), while other studies find that it has no effect on responsiveness (Monogan, Gray, and Lowery 2009; Lascher, Hagen, and Rochlin 1996; Lax and Phillips 2009, 2012). 
ences. On the other hand, term limits could lead to shirking, particularly among legislators not planning to seek another office (Clark and Williams 2014). It could also lead to less experienced legislators, which might reduce their capacity to assess and respond to public opinion. Term limits may also reduce incentives to respond to public opinion by limiting the value of a seat in the legislature (T. Kousser 2005). There have been few empirical studies of the effect of term limits on representation, but one recent study finds that cross-sectional responsiveness is stronger in states with term limits (Lax and Phillips 2012).

Finally, legislative professionalism may affect state governments' responsiveness to public opinion. Some states, such as California, have very professional legislatures that resemble the U.S. Congress, whereas others, such as Vermont, have part-time legislators that meet for only a few weeks a year (Squire 1992, 2007). Professional chambers can use their resources to assess changes in mass opinion. Also, there are greater incentives for lawmakers in professional chambers to be responsive to the public in order to retain office (Maestas 2000). As a result, we might expect states with more professionalized legislatures to be more responsive to public opinion. Two recent studies find that states with higher levels of legislative professionalism are more responsive to public opinion (Pacheco 2013; Lax and Phillips 2012), while another recent study finds no effect on responsiveness (Lax and Phillips 2009).

\section{Modeling Strategy}

Achen (1978) argues that citizens' influence over the government can be measured by the expected difference in government outputs associated with a given difference in the preferences of the average citizen - that is, the regression slope, which he labels responsiveness. ${ }^{8}$ Defined this way, responsiveness is a descriptive quantity: it simply captures the covaria-

8. More precisely, Achen (1978) defines responsiveness as both the intercept and slope of the regression, where the intercept indexes the "bias" of the electoral system (492). Since the intercept in our application has no natural meaning, we focus only on the regression slope, as do most studies of responsiveness. Achen also focuses on the opinions of elected representatives rather than on policy outputs, but there is no difficulty in extending his conception of responsiveness to the latter. As noted by Achen and more recently by Matsusaka (2001), greater responsiveness does not necessarily imply that government outputs more proximate to or congruent with public preferences. 
tion between citizens' preferences and governmental outputs. Due to data limitations, most previous studies have focused on this cross-sectional link between the mass public's policy preferences and government policy. But a major problem with cross-sectional analyses of representation is that it is very difficult to rule out the possibility that some third, unmeasured characteristic of states - its political culture, for example - confounds the relationship between mass liberalism and policy liberalism, or even the possibility that policy liberalism causes mass liberalism.

The normative significance of responsiveness, however, largely hinges on whether the relationship is causal - that is, on whether government outputs would have differed had citizens' preferences been different. ${ }^{9}$ Estimating responsiveness in a causal sense requires isolating exogenous variation in citizens' preferences, a tall order indeed. Nevertheless, such causal inferences can be made more credible by exploiting temporal variation in citizens' preferences. As Stimson, MacKuen, and Erikson (1995, 543) note, representation is a process that is "inherently structured in time." We therefore follow Stimson, MacKuen, and Erikson (1995) and Soroka and Wlezien (2010) in examining the dynamic relationship between mass liberalism and policy liberalism, accounting for policy liberalism's recent history.

Where we depart from these authors is in our use of TSCS data. A time-series-crosssectional approach offers considerable advantages over a purely time-series one. It enables us to estimate a dynamic panel model that includes not only a lagged dependent variable (LDV), as a typical time-series model would, but also state and year fixed effects (FEs). The state and year FEs enable us to rule out two threats to causal inference that time-series data alone cannot: time-invariant state-specific confounders and year-specific shocks that affect all states equally (Angrist and Pischke 2009). ${ }^{10}$ In substantive terms, the state FEs in particular can be interpreted as capturing the policymaking bias unique to each state.

9. This is not to deny that responsiveness in a descriptive sense is also interesting and important. At the very least, the empirical covariation between preferences and policy provides a normative benchmark for the representativeness of a political system.

10. Dynamic panel models suffer from finite-sample bias (Nickell 1981), but when the number of time periods is large, as it is in our case, the bias is a minor concern (Beck and Katz 2011). 
The inclusion of an LDV is also very important, however, for past policies are just the sort of time-varying state-specific confounders that FEs alone cannot account for. ${ }^{11}$ Including an LDV also enables us to analyze how mass liberalism affects policy liberalism over both the short and the long term. In short, while our dynamic panel model cannot rule out all confounders of the opinion-policy relationship, it provides a firmer basis for causal inference than either time-series or cross-sectional analysis alone.

Before describing the details of data and measures, we note a final important element of our empirical strategy, which is to account for the measurement error in our key variables. The main independent and dependent variables in this study - mass liberalism and policy liberalism in each issue domain - are latent quantities whose values must be inferred rather than directly observed. The measurement error in these latent quantities can bias point estimates and standard errors. Thus, in all of our regression analyses, we account for measurement error using a technique known as the "method of composition" (MOC) or "propagated uncertainty" (Tanner 1996, 52; Treier and Jackman 2008, 215-6; Kastellec et al. 2015, 791-2). ${ }^{12}$ The main consequence of these adjustments is to attenuate the estimated effects of mass liberalism by about one-third relative to the unadjusted estimates.

\section{$3 \quad$ Data and Measures}

This section describes the data and measures we use in our analysis. For summary statistics on our key variables, see Supplementary Appendix C.

\subsection{Mass Policy Preferences}

Estimating the relationship between mass preferences and state policies requires measures of each construct for each state in each year. A major difficulty with obtaining such an-

11. State FEs explain only a small amount of additional variation once lagged policy liberalism is controlled for. An $F$ test easily rejects the hypothesis that state FEs add no explanatory power, but a Lagrange multiplier test yields ambiguous conclusions.

12. See Supplementary Appendix D for more details. 
nual measures is that although thousands of Americans have been surveyed on their policy preferences in each year since 1936, the specific survey questions asked have been sparsely and unevenly distributed across time. Moreover, there are often small samples available in any particular year, particularly for smaller states. These challenges make it practically impossible to examine policy-specific responsiveness at the state level over any long time span. The most ambitious existing effort is Pacheco's (2013) analysis of the responsiveness of state education and welfare spending to public preferences for more spending, issues where state-level polling has been particularly dense in the period she covers (1977-2000). Even so, to address sparse survey samples Pacheco smooths the state estimates with multilevel regression coupled with a five-year moving average, which improves the reliability of estimates in smaller states but dampens yearly fluctuations in state opinion (see also Pacheco 2011). Aside from Pacheco (2013), all other studies have dealt with the problem of sparse survey data by using proxies for mass policy preferences derived from ideological self-identification, presidential vote, or the roll-call records of the state congressional delegation (e.g., Erikson, Wright, and McIver 1993; Levitt 1996; Berry et al. 1998).

We take an alternative approach: inferring the latent policy liberalism of state publics by aggregating responses to many distinct policy questions across many polls. We do so using a dynamic, hierarchical group-level item-response model (Caughey and Warshaw 2015; see Supplementary Appendix for more details). While conceptually similar to the estimates of "public policy mood" estimated by Stimson (1991) at the national level and by Enns and Koch (2013) in the states, our mass liberalism measures differ from mood in two respects. ${ }^{13}$ First, mood is a relative measure; it captures whether the public wants more or less government, relative to what is being currently provided. By contrast, our mass liberalism estimates are based only on policy questions that do not explicitly or implicitly reference

13. These works use Stimson's Dyad Ratios algorithm to estimate policy mood. McGann (2014) observes that the Dyad Ratios algorithm has several unappealing features, most notably its ideological asymmetry and its lack of a grounding in a coherent individual-level model. As an alternative, he proposes a group-level IRT model for national mood that is similar to the approach we take. Whereas McGann (2014) captures only longitudinal variation, however, the dynamic, hierarchical group-level IRT model accommodates crosssectional and over-time variation within a common framework. 
the policy status quo and are thus intended as measures of absolute, not relative, liberalism. This is important because the overwhelming majority of survey questions in our data either pertain to national policy or policy in the abstract, not state policies specifically. Our conception of mass liberalism as an absolute measure is thus primarily a practical concession to the available polling data.

A second difference is that we estimate mass liberalism separately for economic and social issues (compare Treier and Hillygus 2009; Stimson, Thiébaut, and Tiberj 2012). ${ }^{14}$ We do so because mass policy preferences across domains have exhibited distinct temporal dynamics and were, until recently, only weakly correlated. This is true not only at the level of individuals, whose lack of issue constraint is well known, but also at the level of geographic or partisan groups, who typically exhibit much more ideological structure than individuals. Thus while treating mass liberalism as unidimensional is often a reasonable approximation in contemporary American politics (see, e.g., Jessee 2009; Tausanovitch and Warshaw 2013), the long time span of our study make it much less tenable.

To estimate mass liberalism in each domain, we rely on a dataset of survey responses to over 300 domestic policy questions spread across nearly 1,000 public-opinion surveys fielded between 1936 and 2014. Overall, the responses of nearly 1.5 million distinct individuals are represented in the data. This dataset includes nearly all policy questions asked on U.S. national surveys in more than one year and the vast majority of questions asked for only a single year, particularly early in the time period when policy questions were sparse. It includes canonical academic surveys, such as the American National Election Study and the General Social Survey, as well as hundreds of polls from commercial polling organizations such as Gallup, CBS News/NYTimes, ABC News/Washington Post, and many others. Out of the 3,846 state-years in our dataset, $95 \%$ contain at least some opinion data on social issues, and $98 \%$ contain at least some data on economic opinion.

As noted above, we estimate economic and social liberalism separately. The economic

14. We also considered estimating liberalism on racial issues as well, but found that the relative paucity of survey questions in this domain made it difficult to estimate racial liberalism over a long time span. 
questions cover issues such as taxes, social welfare, and labor regulation. The social questions include ones about alcohol, abortion, gay rights, women's rights, school prayer, and other cultural (but not racial) issues. In order to ensure the comparability of our estimates over time, we use question series with consistent question wording, substantive meaning, and response categories as bridge items. While no individual survey item is asked consistently between 1936 and 2014, there are many survey questions that are asked consistently for shorter periods of time. These items glue our estimates from one time period together with our estimates for other time periods. Since almost all these surveys also include a question about party identification, we use the same dataset to estimate the proportions of Democrats, Republicans, and Independents in each state year.

To construct our measure of mass liberalism, we first used a dynamic group-level IRT model to estimate annual average liberalism in groups defined by state, race, and urban residence. ${ }^{15}$ Then, using data from the U.S. Census (Ruggles et al. 2010), we poststratified the group estimates to match the groups' proportions in the state population to produce estimates of average liberalism in each state-year. Finally, to aid interpretability of the estimates we standardized them to have a mean of 0 and a variance of 1 across state-years.

Figure 1 maps our estimates of mass social and economic liberalism in 1940, 1975 and 2010. The cross-sectional patterns are generally quite sensible-New York, California, and Massachusetts are always among the most liberal states. However, it is worth noting that the southern states are typically more conservative on the social dimension than the economic dimension. Moreover, the states have remained generally stable in their relative liberalism, consistent with Erikson, Wright, and McIver's (2006) finding that state publics have been stable in terms of ideological identification. According to our estimates, mass liberalism has shifted substantially over time in only a few states. States in New England have become more liberal, while states such as Idaho and Louisiana have become more conservative.

15. We estimate the IRT model using the R package dgo (Dunham, Caughey, and Warshaw 2016). Supplementary Appendix A provides more details on the model estimation procedure and Supplementary Appendix $\mathrm{B}$ demonstrates the validity of the estimates. 

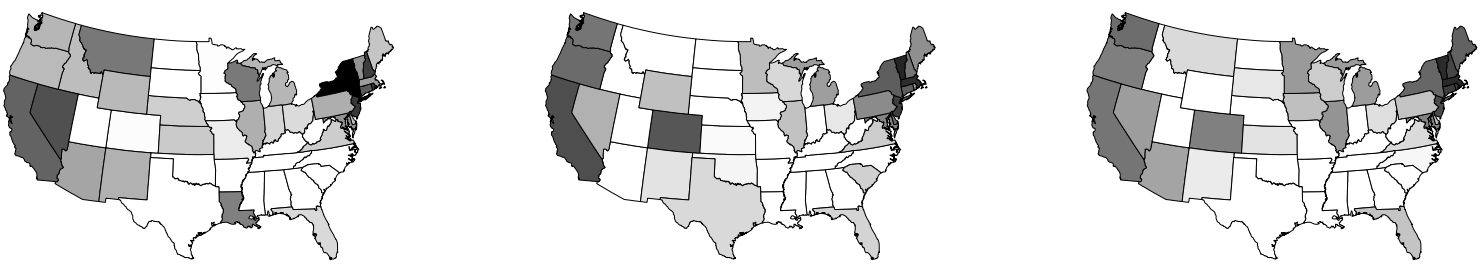

(a) Mass Social Liberalism

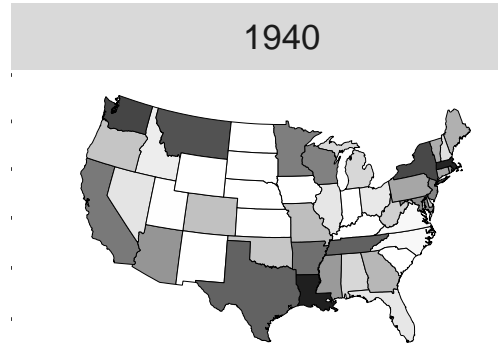

1975

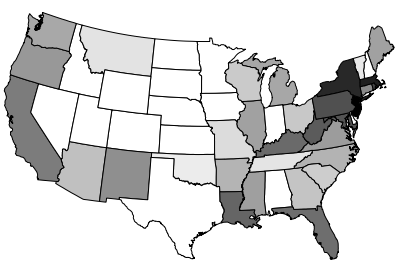

(b) Mass Economic Liberalism

Figure 1: Mass liberalism by state, 1940-2010. Darker shading indicates more liberal opinion. To accentuate the color contrasts, the estimates in this figure are standardized within year.

\subsection{State Policies}

We next require a measure of the liberalism of state policies. For consistency with our domain-specific measures of mass liberalism, we separate state policy liberalism by domain as well, using the measures of economic and social policy liberalism estimated by Caughey and Warshaw (2016). It is worth noting, however, that throughout the period we examine, there has consistently been a much higher correlation between the liberalism of states' economic and social policies than between the economic and social liberalism of state mass publics.

These measures of domain-specific policy liberalism are based on a total of nearly 150 individual state policies. The scores are estimated using a dynamic Bayesian factor-analytic model for mixed data, which allows the inclusion of both continuous and ordinal indicators of state policy. ${ }^{16}$ The policy dataset underlying the policy liberalism scores is designed to

16. The model, which extends that of Quinn (2004), is dynamic in that policy liberalism is estimated 
include all politically salient state policy outputs on which comparable data are available for at least five years. ${ }^{17}$ The economic dimension covers a wide range of policy areas, including social welfare (e.g., AFDC/TANF benefit levels), taxation (e.g., income tax rates), labor (e.g., right-to-work), and the environment (e.g., state endangered species acts). The social dimension includes women's rights (e.g., jury service for women), morals legislation (e.g., anti-sodomy laws), family planning (e.g., ban on partial birth abortion), religion (e.g., public schools can post the Ten Commandments), criminal justice (e.g., death penalty), and drugs (e.g., marijuana decriminalization).

\subsection{Institutions}

Our data on potential institutional moderators of dynamic responsiveness are drawn from various sources. We obtained data on suffrage restrictions (poll taxes and literacy tests) from Springer (2014). We drew our data on campaign finance regulations (limits on the contributions of individuals, corporations, and unions) from a wide range of sources. These include state statutes, academic analyses (Stratmann and Aparicio-Castillo 2006; La Raja and Schaffner 2014), various editions of The Book of the States and the FEC's Analysis of Federal and State Campaign Finance Law, and other reference works (e.g., Ford 1955; Alexander and Denny 1966). Data on reforms intended to enhance citizen governance (direct democracy and term limits) were obtained from Matsusaka (2008) and from the National Conference of State Legislatures. There are no existing measures of legislative professionalism that span our entire time period. ${ }^{18}$ Thus, we construct a simple measure of latent legislative professionalism using the natural log of the number of days that each state legislature is in

separately in each year and the policy-specific intercepts (or "difficulties") are allowed to drift over time. If, instead, the intercepts are held constant, the policies of all states are estimated to have become substantially more liberal, especially before the 1980s. Each policy's factor loading (or "discrimination"), which captures how "ideological" the policy is, is held constant over time.

17. Unlike many studies, the dataset explicitly excludes social outcomes (e.g., infant-mortality rates) as well as more fundamental government institutions (e.g., legislative term limits).

18. This is largely due to the fact that data on staff and budgets are not readily available before the 1970 s. 
session during a two year period based on data from the Book of the States. ${ }^{19}$ Data on the partisanship of state officials comes from Klarner (2013).

\section{Responsiveness: Cross-Sectional and Dynamic}

We now turn to the relationship between mass liberalism and the liberalism of government policies. We begin with a cross-sectional analysis typical of most studies of responsiveness. Figure 2 plots the state-level relationship between mass liberalism and policy liberalism separately by policy domain (social and economic), time period (before and since 1972), and region (South and non-South). Within time period, each state's mass and government liberalism have been averaged across years, so these relationships can be interpreted roughly as the average cross-sectional responsiveness in each domain, period, and region.

Figure 2 reveals several noteworthy patterns. First, in the period before 1972, when disenfranchisement and lack of partisan competition were still very much live issues in Southern states, mass and government policy liberalism were essentially uncorrelated within that region. ${ }^{20}$ By contrast, in the more democratic non-South, government policy liberalism has always had a robust relationship with mass liberalism. The relationship in the non-South has strengthened somewhat over time, with the correlation increasing from 0.49 to 0.74 on social issues and from 0.41 to 0.72 on economic issues. The cross-sectional correlation on social issues has increased in the South as well (to 0.44 in the post-1972 period), but the economic policies of Southern states remain essentially uncorrelated with public opinion as well as substantially more conservative than in non-Southern states.

These regional differences in cross-sectional responsiveness can also be seen in columns (1) and (4) of Table 1, which report estimates of cross-sectional responsiveness on social

19. Data on legislative days were missing for $15 \%$ of state-term dyads. We linearly interpolated the (logged) missing values within states using the R package Amelia (Honaker, King, and Blackwell 2011). The cross-sectional correlation between our measure of professionalism and the more holistic measures from 1979, 1986, 1996, and 2003 in Squire (2007) is 0.7.

20. Mickey (2015) argues that the democratization of the former Confederacy was not complete until 1972. For the classic critique of the South's one-party system, see chapter 14 of Key (1949). 
Social
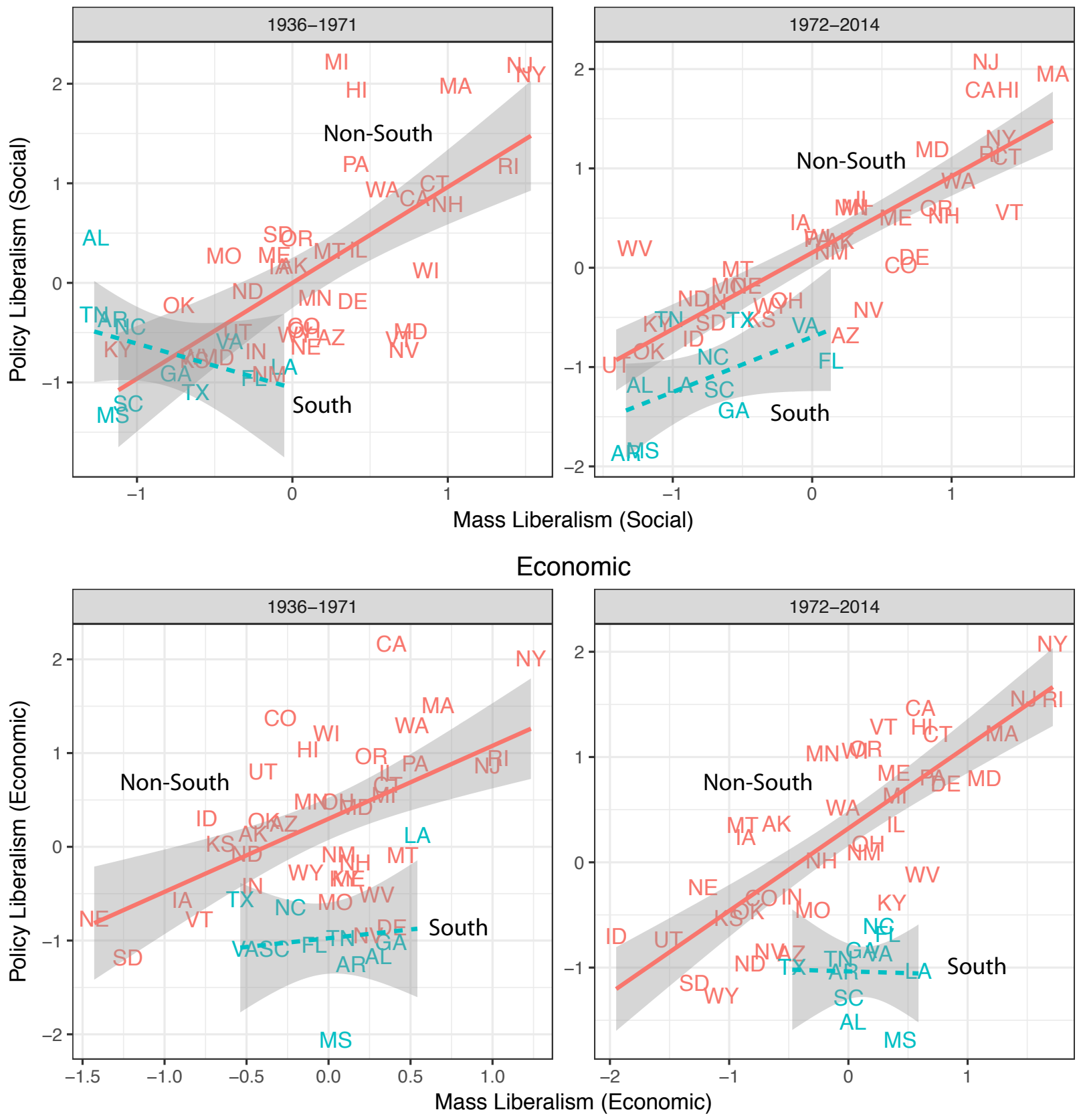

Figure 2: Cross-sectional relationship between mass and government policy liberalism, by era and issue domain.

and economic issues, respectively, averaged over the entire 1936-2014 period. (Note that these estimates correct for measurement error in the liberalism measures.) All the variables in this table are scaled to have a standard deviation (SD) of 1 across state-years. As the main effect of Mass Liberalism L $_{-1}$ in column (1) indicates, outside the South there is nearly 
a one-to-one cross-sectional relationship between mass and policy liberalism on social issues: a 1-SD difference on one is associated with a $0.8-\mathrm{SD}$ difference in the other. On economic issues, the opinion-policy relationship in the non-South is only slightly less strong. But as the interactions with South show, cross-sectional responsiveness on social issues is about half as strong in the South as in the non-South, and on economic issues is wholly absent.

Quite a different conclusion emerges, however, if we examine responsiveness from a dynamic rather than cross-sectional perspective. A first cut at such an over-time perspective is provided by columns (2) and (5) of Table 1, which report the results of specifications that include fixed effects (FEs) for state as well as year. These specifications capture the opinion-policy relationship within states net of national trends, thus eliminating the influence of time-invariant state-specific confounders. The estimates indicate that, in both regions, state-years in which mass liberalism was higher than average for that state also tended to have higher-than-average policy liberalism. Taken at face value as causal estimates, the coefficients from the two-way FE model are strikingly large. They imply that in the non-South, a 1-SD change in mass liberalism has an immediate effect of 0.44 SDs on social policy liberalism and 0.35 SDs on economic policy liberalism. On economic issues, the opinion-policy relationship again disappears in the South, but on social issues it is if anything stronger than in the non-South.

These inferences, however, hinge on the standard assumptions of two-way FE models, notably that there are no state-specific time-varying confounders. One very obvious such confounder is past state policies, which influence future policies in the direct sense of being path dependent and difficult to change. The responsiveness estimates in column (3) and (6), which control for lagged policy liberalism instead of state FEs, are an order of magnitude smaller in magnitude. As indicated by the lag coefficients, policy liberalism in both domains is powerfully predicted by its lagged values (though the lag coefficient is clearly less than 1 , indicating mean-reversion). Adding state FEs back in, as in columns (4) and (8), shrinks the estimates only a little further. Nevertheless, all specifications supply evidence that non- 


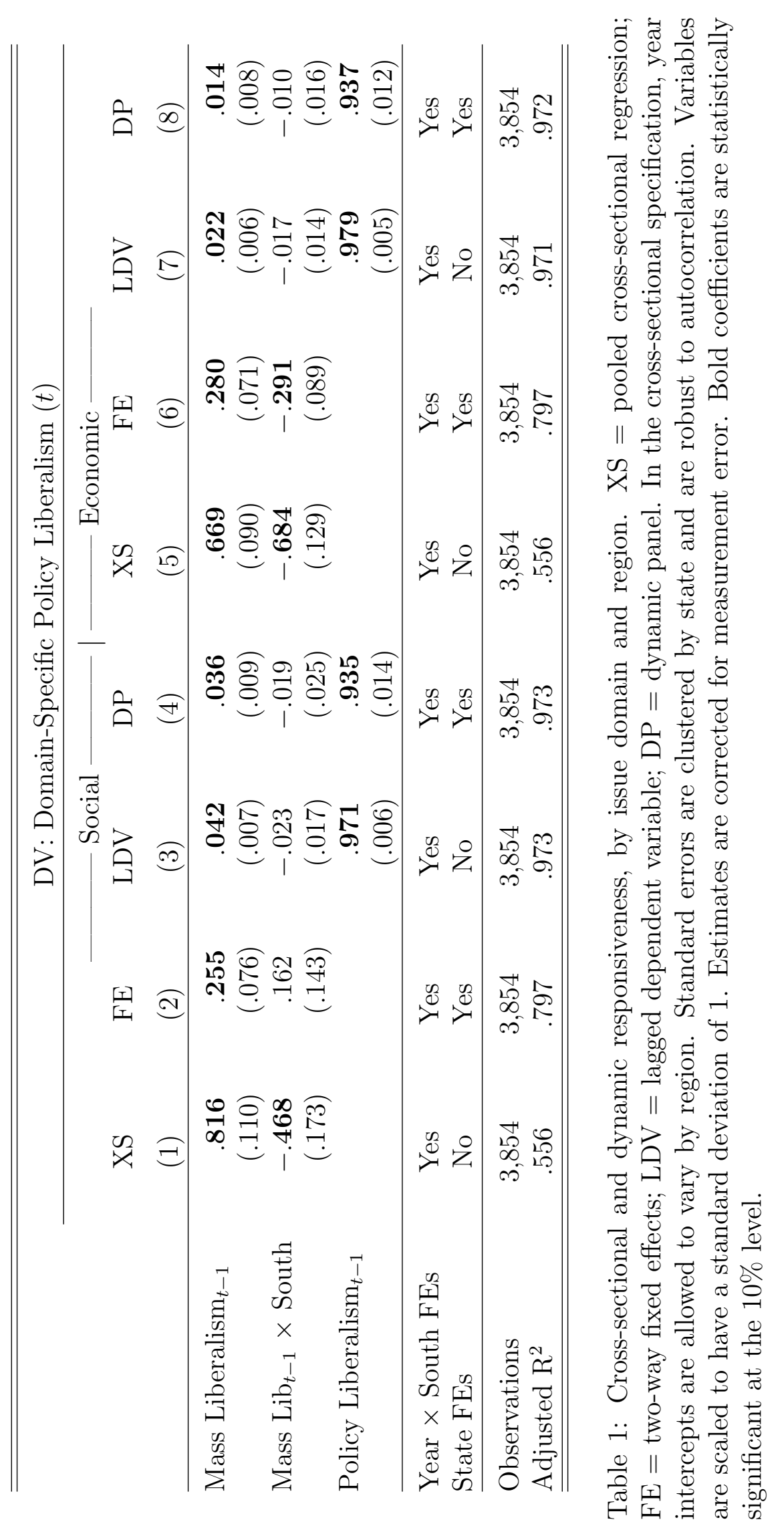


Southern states are responsive to their publics. Although the regional interactions in the dynamic models are statistically insignificant, we also cannot reject the hypothesis of no responsiveness in the South, especially on economic issues (we explore this further in our discussion of moderators below).

Consistent with our expectations regarding differences across policy domains, the substantive magnitude of dynamic responsiveness appears to be greater on social than economic issues. Averaging across regions, the dynamic panel model estimates a standardized opinion effect of 0.032 for social policy as compared to 0.012 for economic policy. That is, the policy effect of a 1-SD difference in mass opinion is almost three times larger on social than economic issues. Even on social issues, however, the immediate effect of mass liberalism is still an order of magnitude smaller than what the two-way FE estimates naively imply. ${ }^{21}$

Due to policy liberalism's strong persistence over time, however, the long-term effects of mass liberalism are much larger than the immediate effect. One way to see this is to calculate the long-run multiplier of Mass Liberalism $_{t-1}$, which can be interpreted as the total effect of a permanent one-unit increase in mass liberalism over all future time periods (De Boef and Keele 2008, 191). On social issues, the estimated long-run multiplier of Mass Liberalism $_{t-1}$ is $0.57(\mathrm{SE}=0.17)$ in the non-South and $0.21(0.30)$ in the South. On economic issues, the analogous estimates are $0.23(0.12)$ for the non-South and $0.03(0.11)$ for the South. That is, if the public of a non-Southern state suddenly became 1 unit more liberal on social issues, we would expect the state's social policy liberalism to eventually settle at a new equilibrium 0.57 units above its old equilibrium (assuming no national trends in social liberalism). ${ }^{22}$ The effect would occur gradually, however. It would take more than a decade, for example, for $50 \%$ of the long-run effect to be realized, and half a century for $95 \%$ to be realized. Note that compared to the immediate dynamic effects of Mass Liberalism, the long-run effects are much closer in magnitude to the cross-sectional relationships reported in Table 1. This is

21. Supplementary Appendix F shows the robustness of these results to other model specifications.

22. This equilibrium is the point at which the effect of Mass Liberalism is exactly counterbalanced by the mean-reverting impact of the lagged dependent variables. 
consistent with the hypothesis that the strong contemporaneous correlation between state policies and opinion is the product of the long-term, gradual accumulation of incremental policy responses to mass preferences.

\section{Mechanisms: Partisan Turnover and Adaptation}

As noted earlier, dynamic responsiveness to popular preferences can occur by two main mechanisms: partisan selection and adaptation. Partisan selection is a two-step process. First, voters' liberalism must affect their probability of electing candidates of one party over another. Second, the newly elected officials must implement different policies than their opponents would have. In short, if greater liberalism in the public causes the election of more Democrats, and electing more Democrats causes policies to become more liberal, then partisan selection mediates the effect of opinion on policy. Adaptation, by contrast, is that portion of dynamic responsiveness not mediated by the selection of candidates of one party or another, but rather is the result of officials in each party responding directly to shifts in public sentiment. In sum, evaluating the relative importance of partisan selection and adaptation entails estimating three causal effects: the effect of mass liberalism on party control of government, the effect of party control on policy liberalism, and the effect of mass liberalism on policy liberalism with party control held constant.

We begin our empirical analysis with the first effect, that of mass liberalism on party control. To measure the latter concept, we create indicators for whether the Democratic Party controls the governorship, the lower house of the state legislature, and the upper house. We combine these indicators into a single summative index of Democratic Control, normalized to range from 0 to $1 .^{23}$ Except in rare circumstances, Democratic Control can change only in years following state elections, which in all but four states occur in even years. We therefore subset to years that follow a state election, estimating the effect on Democratic

23. We focus on legislative control rather than seat share because in dynamic models, the Democratic share of all legislative seats is not a significant predictor of policy liberalism. Controlling for legislative seat share does not qualitatively affect our conclusions. 


\begin{tabular}{|c|c|c|c|c|}
\hline & \multicolumn{4}{|c|}{ DV: Democratic Control Index $(t)$} \\
\hline & $(1)$ & $(2)$ & $(3)$ & $(4)$ \\
\hline Mass Social Lib $\mathrm{L}_{t-1}$ & $\begin{array}{r}.030 \\
(.016)\end{array}$ & & $\begin{array}{r}.027 \\
(.016)\end{array}$ & $\begin{array}{c}.021 \\
(.015)\end{array}$ \\
\hline Mass Econ Lib $\mathrm{Li}_{t-1}$ & & $\begin{array}{c}.021 \\
(.012)\end{array}$ & $\begin{array}{c}.016 \\
(.013)\end{array}$ & $\begin{array}{c}.013 \\
(.013)\end{array}$ \\
\hline Mass Dem PID PI-2 & & & & $\begin{array}{r}.075 \\
(.010)\end{array}$ \\
\hline Dem Control $_{t-1}$ & $\begin{array}{r}.662 \\
(.035) \\
\end{array}$ & $\begin{array}{r}.667 \\
(.036) \\
\end{array}$ & $\begin{array}{r}.661 \\
(.037)\end{array}$ & $\begin{array}{r}.592 \\
(.032) \\
\end{array}$ \\
\hline Year FEs & Yes & Yes & Yes & Yes \\
\hline State FEs & Yes & Yes & Yes & Yes \\
\hline Observations & 1,755 & 1,755 & 1,755 & 1,497 \\
\hline Adjusted $\mathrm{R}^{2}$ & .718 & .717 & .718 & .721 \\
\hline
\end{tabular}

Table 2: Effect of mass policy preferences and partisanship on partisan turnover. The data have been subsetted to years following state elections, which in most states are odd years. Standard errors are clustered by state and are robust to autocorrelation. The Democratic Control Index ranges from 0 to 1 . Other variables are scaled to have a standard deviation of 1 across state-years.

Control of mass liberalism in the preceding election year.

Table 2 summarizes the results of this analysis, which employs a dynamic panel specification similar to Table 1. As indicated by the coefficients for Democratic Control $_{t-1}$ in the bottom row, the partisan composition of the legislature is moderately autocorrelated, but not nearly as much so as policy, suggesting a fairly strong tendency towards alternation in party control over time. ${ }^{24}$ More relevant to our purposes here, the first and second rows of Table 2 show that Mass Liberalism ${ }_{t-1}$ (that is, in the most recent election year) has a modest effect on changes in party control. A 1-SD difference in mass social liberalism increases Democratic Control by 0.03 (column 1), and an analogous increase in economic liberalism does so by 0.02 (column 2). When mass social and economic liberalism are included in the same specification (column 3), mass economic liberalism is no longer distinguishable from 0 ,

24. This is consistent with the finding that a party that narrowly wins the governorship (Folke and Snyder 2012) or state legislature (Feigenbaum, Fouirnaies, and Hall, Forthcoming) tends to lose seats in the next election. 
but the sum of the two coefficients $(0.042, \mathrm{SE}=0.018)$ remains clearly positive.

One potential concern with these results is that the apparent effect of mass liberalism may be confounded by Democratic party identification. That is, the proportion of Democratic identifiers in the public may affect both mass liberalism and voters' willingness to elect Democrats. Column (4) assesses this possibility by controlling for Mass Democratic $P I D_{t-2}$, the year before mass liberalism is measured. Mass Democratic PID ${ }_{t-2}$ clearly has a powerful effect on Democratic Control, increasing the proportion of government controlled by Democrats by 0.08 for each SD change. ${ }^{25}$ Accounting for mass PID modestly reduces the magnitude and significance of the mass liberalism coefficients, but the two liberalism coefficients still jointly predict Democratic Control $(p=0.05) \cdot{ }^{26}$ Still, mass policy preferences are clearly a much less powerful predictor of election outcomes than mass partisanship.

The preceding analysis thus shows that mass liberalism has a modest predictive effect on Democratic control, even accounting for the partisan leanings of the mass public. In order for partisan selection to be a mechanism of dynamic responsiveness, however, the partisan composition of the government must also affect the liberalism of state policies. As many classic studies of state politics emphasize, the cross-sectional relationship between Democratic control and policy liberalism is actually close to 0, or even negative (e.g., Erikson, Wright, and McIver 1993). But more recent analyses employing panel and RD designs have shown that Democratic control of the governorship or legislature modestly increases the liberalism of state policies (e.g., Brown 1995; Caughey, Warshaw, and Xu, Forthcoming).

We replicate this latter finding in columns (1) and (5) of Table 3, which show the effect of Democratic Control Cn Policy Liberalism $_{t}$ in the economic and social domains, respectively. (For this analysis we use the full sample of years.) In both domains, going from full Republican to full Democratic control of the elected branches increases domain-specific

25. Note that Mass Democratic PID ${ }_{t-2}$ cannot affect Democratic Control $_{t-1}$ because the latter is determined by the election in year $t-3$.

26. This remains true if we control instead for Mass Democratic $P I D_{t-1}$, which may be a consequence as well as a cause of mass liberalism in the same year $(p=0.08)$. 


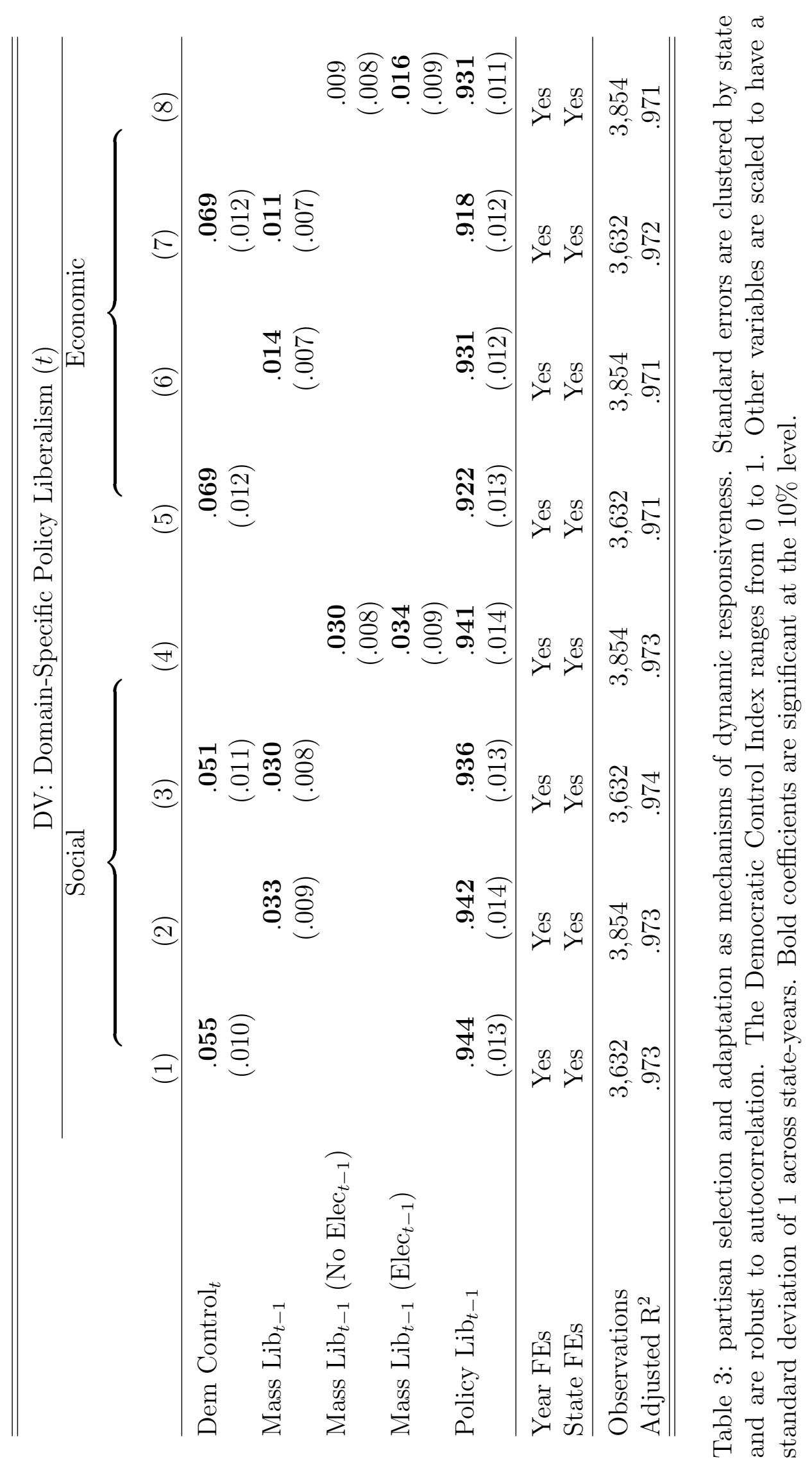


policy liberalism in that year by $0.05-0.07 \mathrm{SDs}^{27}$ Such complete switches in party control are rare, however. The standard deviation of Democratic Control is .39, which corresponds to a shift in one of the three government institutions that compose the index. By this standard, the effect of Democratic Control is roughly comparable to that of mass liberalism. The standardized effect of Democratic Control is 0.021 for social policy and 0.027 for economic, about the same size as the standardized effect of mass liberalism in each domain.

To assess the degree to which the effect of opinion on policy is mediated by party control (that is, through the mechanism of partisan selection), we rely on three complementary analyses. The first is to simply multiply the estimated effects of mass liberalism on Democratic control and Democratic control on policy liberalism. This method estimates the mediated effect to be $0.0016(\mathrm{SE}=0.0009)$ for social policy and $0.0014(0.0009)$ for economic. These estimates are about 5-10\% of the total effects of mass liberalism reported in columns (2) and (6) of Table 3. Very similar results are obtained if we use a different method: subtracting the controlled direct effect of Mass Liberalism L $_{-1}$ (column 3/7) from its estimated total effect (column 2/6). ${ }^{28}$

Finally, the same pattern appears if we hold Democratic control fixed by design rather than through statistical control. We do this by comparing dynamic responsiveness in years that follow an election, when party control could conceivably change, with years not following an election, when it will generally be the same as in the previous year. Responsiveness in years where only adaptation is possible is captured by the coefficients labeled "Mass $\operatorname{Lib}_{t-1}\left(\right.$ No Elec $\left._{t-1}\right)$ " in columns (4) and (8). Note that these coefficient estimates are nearly identical to their counterparts in columns (3) and (7), though in the case of economic policy we cannot reject zero responsiveness in years that do not follow elections. It is worth noting that dropping years after an election implicitly rules out not only change in party control, but (aside from mid-term departures) any incumbent turnover. The fact that this approach

27. These dynamic-panel estimates are similar in magnitude to the electoral RD estimates of the effects of Democratic governors and state legislatures reported in Caughey, Warshaw, and Xu (Forthcoming).

28. The results are qualitatively identical if we also control for Democratic seat share in the legislature. 
yields estimates very close to those obtained by controlling explicitly for Democratic Control suggests that most of adaptation is explained not by within-party turnover or changes in the size of partisan majorities, but by the evolving positions of individual incumbents.

Given the imprecision of the mediation estimates and the strong assumptions required to interpret them causally, we should not focus too much on their exact magnitude. It is nevertheless striking how little support the mediation analyses provide for partisan selection as a mechanism of responsiveness. This is true not because party control has no policy effects - they are in fact quite large and robust - but rather because mass liberalism is only weakly related to shifts in party control. These results thus leave substantial scope for responsiveness in the absence of changes in party control. While we cannot determine exactly how much of the adaptation effect is due to within-party membership turnover, the evidence supports the hypothesis that the adaptation of reelection-motivated incumbents to shifts in public sentiment is an important, and perhaps the dominant, mechanism of responsiveness.

\section{Heterogeneity: Time, Region, and Institutions}

In addition to operating through multiple mechanisms, dynamic responsiveness may also be stronger under certain conditions than others. In other words, there may be factors that moderate the effect of opinion on policy. Here we examine six such factors: time, region, suffrage restrictions, campaign contribution limits, reforms designed to enhance citizen participation in government, and legislative professionalism. Unlike time and region, the last four moderators are institutions that could potentially be manipulated to influence the quality of responsiveness. We emphasize, however, that the interaction effects in the analysis below are purely observational, and nothing about the research design ensures that the effects are not confounded by other attributes of the states where these institutions were adopted. Moreover, an increase in responsiveness due to a particular institution does not necessarily imply that it makes policy more congruent with mass preferences (Matsusaka 2001). 


\begin{tabular}{|c|c|c|c|c|c|c|}
\hline & \multicolumn{6}{|c|}{ DV: Domain-Specific Policy Liberalism $(t)$} \\
\hline & \multicolumn{3}{|c|}{$\longrightarrow$ Social } & \multicolumn{3}{|c|}{ Economic -} \\
\hline & $(1)$ & $(2)$ & $(3)$ & $(4)$ & $(5)$ & $(6)$ \\
\hline Mass Liberalism $_{t-1}$ & $\begin{array}{r}.040 \\
(.009)\end{array}$ & $\begin{array}{l}.039 \\
(.010)\end{array}$ & $\begin{array}{r}.044 \\
(.013)\end{array}$ & $\begin{array}{r}.020 \\
(.008)\end{array}$ & $\begin{array}{r}.025 \\
(.008)\end{array}$ & $\begin{array}{r}.024 \\
(.009)\end{array}$ \\
\hline Mass Lib $_{t-1} \times$ Pre-' 72 & $\begin{array}{r}-.031 \\
(.015)\end{array}$ & $\begin{array}{c}-.021 \\
(.016)\end{array}$ & $\begin{array}{c}-.021 \\
(.020)\end{array}$ & $\begin{array}{r}-.023 \\
(.012)\end{array}$ & $\begin{array}{r}-.026 \\
(.014)\end{array}$ & $\begin{array}{c}-.024 \\
(.015)\end{array}$ \\
\hline Mass $\operatorname{Lib}_{t-1} \times$ South & & $\begin{array}{c}-.017 \\
(.013)\end{array}$ & $\begin{array}{c}-.004 \\
(.022)\end{array}$ & & $\begin{array}{r}-.024 \\
(.013)\end{array}$ & $\begin{array}{r}-.031 \\
(.015)\end{array}$ \\
\hline Mass Lib ${ }_{t-1} \times$ Pre-' $72 \times$ South & & $\begin{array}{l}.003 \\
(.030)\end{array}$ & $\begin{array}{c}-.006 \\
(.034)\end{array}$ & & $\begin{array}{c}.021 \\
(.018)\end{array}$ & $\begin{array}{l}.029 \\
(.022)\end{array}$ \\
\hline Suffrage Restriction & & & $\begin{array}{l}.014 \\
(.011)\end{array}$ & & & $\begin{array}{l}.002 \\
(.015)\end{array}$ \\
\hline Suff Restrict $\times$ Mass $\operatorname{Lib}_{t-1}$ & & & $\begin{array}{l}.00002 \\
(.015)\end{array}$ & & & $\begin{array}{l}.00004 \\
(.012)\end{array}$ \\
\hline Contribution Limits & & & $\begin{array}{c}-.001 \\
(.003)\end{array}$ & & & $\begin{array}{c}-.0004 \\
(.003)\end{array}$ \\
\hline Contrib Limit $\times$ Mass $\operatorname{Lib}_{t-1}$ & & & $\begin{array}{l}.002 \\
(.004)\end{array}$ & & & $\begin{array}{l}.004 \\
(.003)\end{array}$ \\
\hline Citizen Governance & & & $\begin{array}{r}-.006 \\
(.016)\end{array}$ & & & $\begin{array}{r}-.006 \\
(.016)\end{array}$ \\
\hline Citizen Gov $\times$ Mass Lib ${ }_{t-1}$ & & & $\begin{array}{c}.010 \\
(.010)\end{array}$ & & & $\begin{array}{c}.005 \\
(.008)\end{array}$ \\
\hline Legislative Days (Logged) & & & $\begin{array}{l}.006 \\
(.009)\end{array}$ & & & $\begin{array}{r}-.010 \\
(.006)\end{array}$ \\
\hline Leg Days $\times$ Mass Lib $_{t-1}$ & & & $\begin{array}{l}.003 \\
(.008)\end{array}$ & & & $\begin{array}{r}-.006 \\
(.006)\end{array}$ \\
\hline Policy Liberalism $_{t-1}$ & $\begin{array}{r}.936 \\
(.013) \\
\end{array}$ & $\begin{array}{r}.934 \\
(.014) \\
\end{array}$ & $\begin{array}{r}.918 \\
(.016) \\
\end{array}$ & $\begin{array}{r}.927 \\
(.012) \\
\end{array}$ & $\begin{array}{r}.925 \\
(.013) \\
\end{array}$ & $\begin{array}{r}.919 \\
(.014) \\
\end{array}$ \\
\hline Year FEs & Yes & Yes & Yes & Yes & Yes & Yes \\
\hline State FEs & Yes & Yes & Yes & Yes & Yes & Yes \\
\hline Observations & 3,854 & 3,854 & 3,552 & 3,854 & 3,854 & 3,552 \\
\hline Adjusted $\mathrm{R}^{2}$ & .973 & .973 & .970 & .971 & .971 & .970 \\
\hline
\end{tabular}

Table 4: Moderators of dynamic responsiveness. Standard errors are clustered by state and are robust to autocorrelation. Continuous variables are scaled to have a standard deviation of 1 across state-years. Bold coefficients are significant at the $10 \%$ level.

That being said, it is nonetheless interesting and important to assess whether and how dynamic responsiveness differs across contexts. The first context we examine is historical era. Has dynamic responsiveness increased over time? The answer seems to be yes. ${ }^{29}$ We can see

29. This conclusion relies on the assumption that the mass and policy liberalism scales are comparable 
this most clearly in columns (1) and (4) of Table 4, which interact Mass Liberalism Li-1 $_{\text {with }}$ an indicator for years before 1972. On both social and economic issues, dynamic responsiveness was significantly smaller before 1972. In fact, on economic issues the point estimate for the earlier period is close to 0 .

Why might dynamic responsiveness have increased over time? One natural hypothesis is that it was driven by the democratization of the South, which was not fully democratic until the early 1970s (Mickey 2015). Surprisingly, we actually find little evidence for this conjecture. This can be seen in columns (2) and (5), which include a three-way interaction between mass liberalism, era, and region. The estimates in the second row, which now capture temporal differences in the non-South only, are of similar magnitude to those in columns (1) and (4). The coefficients in the third row indicate that responsiveness has been lower in the South even in the post-1972 period. Moreover, the triple interaction in the fourth row provides no evidence that the regional gap in dynamic responsiveness was once larger than it is now. In fact, column (5) seems to suggest that on economic issues Southern and non-Southern states were once about equally (un)responsive, whereas in recent years dynamic responsiveness has increased in the non-South but not in the South. ${ }^{30}$

One possible response to this puzzling finding is that undemocratic institutions such as poll taxes were not confined to Southern states, nor did all Southern states employ these devices over the entire pre-1972 period. It would be better, therefore, to examine the moderating effects of suffrage restrictions directly. By the same token, states have adopted numerous other reforms designed to limit the influence of money in politics and enhance

across years. We believe this assumption is more plausible for these measures than for other commonly used latent scales. What bridges NOMINATE scores between congresses, for example, is not repeated votes on the same bills, but rather assumptions about whether and how members of Congress change ideologically over time (Poole and Rosenthal 2007). By contrast, the bridging assumption in our analysis is that the discrimination parameters of survey questions and state policies repeated across years are constant over time. That is, the degree to which a question or policy distinguishes liberal and conservative states is assumed to be the same in every year. This is the same assumption that is implicitly invoked by studies that compare responsiveness on a single issue over time. Supplementary Appendix E provides further evidence that these results are not driven by differential measurement error across time.

30. However, when we subsample our opinion data to ensure equal sample sizes across time and re-run the models in Table 4, the results suggest that on economic issues responsiveness has increased roughly equally across regions (see Online Appendix E). We thus view these regional differences with some skepticism. 
citizens' participation in policymaking. State legislatures have also generally become more professionalized over time, though at different rates, and this too may have influenced responsiveness. To assess these possibilities, we examine whether the effect of Mass Liberalism $_{t-1}$ is moderated by three indices of related policies - suffrage restrictions (poll tax and literacy test), campaign contribution limits, and citizen governance (direct democracy and term limits) - and by the number of days a legislature spends in session (a proxy for professionalism). We present the analysis of these policies as indices (all centered at 0) in order to ameliorate the multiplicity problem of testing many interaction effects.

On the whole, we find little evidence that any of the institutions we consider moderate the effect of opinion on policy. Controlling for era and region, none of eight index interactions is statistically significant. ${ }^{31}$ In this specification, the only significant association we find is for the main effect of logged legislative days, which appears to have a negative association with economic policy liberalism when that variable is at its mean. Essentially the same picture emerges if we analyze each institution individually (see Supplementary Appendix G).

In sum, our main findings are that the dynamic effect of opinion on policy is stronger in the present era than it was before 1972, and that in the modern era dynamic responsiveness seems to be stronger in non-Southern states, at least on economics. We find little evidence that any institution we considered moderates dynamic responsiveness. Given that the interaction effects are essentially correlational estimates, however, we should not draw firm conclusions either way about the causal effect of these institutions. It is possible, for example, that reforms such as contribution limits are implemented precisely to counteract a particularly unresponsive state government, masking these reforms' positive effects. Thus, while our results suggest that previous studies may overstate the responsiveness-enhancing

31. Controlling for mass liberalism's interactions with era and region is important because the latter strongly predict the likelihood of adopting the reforms we consider and thus proxy for the numerous other factors that vary across time and geography that might confound the institutional interactions. However, if we drop these controls, we do find some suggestive evidence consistent with the hypotheses that suffrage restrictions inhibit responsiveness while campaign finance regulations and citizen governance reforms enhance it. The strongest evidence is for the campaign finance index, a 1-SD increase of which is estimated to increase responsiveness on economic issues by $0.0082(\mathrm{SE}=0.0047)$. 
effects of these institutional reforms, this is clearly an area where more research is needed.

\section{Discussion}

What do our findings suggest about the character and functioning of American democracy? At the most basic level, they indicate that state policymaking responds to mass policy preferences, though more so now than in the past. Given the particularly high barriers to responsiveness in state politics - limited state control over some policies, the competitive constraints of federalism, citizens' inattentiveness to state politics - this fact alone should provide a counter to more pessimistic accounts of American democracy. Our results also call into question an emerging scholarly sense, approaching a consensus, that partisan selection is the dominant if not exclusive means by which voters affect government policies. Manifestions of this quasi-consensus can be seen in theoretical work that stresses candidates' inability to commit to moderate policies (e.g., Alesina 1988; Besley and Coate 1997), causal analyses that find little evidence of adaptation or convergence in Congress (e.g., Lee, Moretti, and Butler 2004; Fowler and Hall 2016), and studies that emphasize the "leapfrog" nature of representation in the contemporary United States (e.g., Bafumi and Herron 2010; Lax and Phillips 2012). By contrast, our finding that adaptation is a major and perhaps the dominant mechanism of responsiveness is consistent with classic studies that emphasize politicians' attentiveness to public sentiment and their capacity and incentives to adapt to shifts in mass opinion (e.g., Mayhew 1974; Arnold 1990; Stimson, MacKuen, and Erikson 1995).

It should be emphasized that partisan selection is a comparatively minor mechanism of responsiveness not because party control has no policy effects, but rather because mass policy preferences explain relatively little of the variation in party fortunes. In other words, both public opinion and party control affect state policies, but variation in one is not strongly related to the other. This suggests an important qualification to the dim view, expressed by Achen and Bartels (2016) and others, that the apparently weak relationship between mass 
liberalism and partisan fortunes implies that citizens have little influence over government policies. Rather, mass liberalism and party control seem to exert fairly independent, and roughly equally important, effects on policy change. This pattern is consistent with Erikson et al.'s "statehouse democracy" model, in which the platforms of Democratic and Republican parties in a given state diverge from one another (resulting in partisan effects on policy) but are roughly centered on the state's median voter (resulting in adaptation). Contrary to some fears, however, neither party control nor mass liberalism seems to cause dramatic swings in policymaking. Even a full switch in party control, for example, changes policy liberalism in the short term by less than a tenth of a standard deviation. In general, large shifts in policy liberalism occur only through the compounding of many small responses to party control and mass preferences. It is the cumulation of such incremental changes over many decades that arguably accounts for the strong cross-sectional relationship between opinion and policy.

In these respects, then, our findings provide some reassurance regarding the health of American democracy. In other respects, however, our analyses are indeterminate or even pessimistic. First, since our measures of mass and state policy liberalism are not on the same scale, we cannot directly evaluate whether state policies are congruent with mass preferences at any given moment (cf. Achen 1978; Matsusaka 2001; Lax and Phillips 2012). In particular, the fact that state policymaking is responsive on the margin does not preclude the existence of ideological bias in state policies. Indeed, the persistent gap in policy liberalism between Southern and non-Southern states with similar mass publics (see Figure 2) implies that the policies of one set of states are systematically biased in a liberal or conservative direction. Relatedly, our results do not rule out the possibility of differential responsiveness across subsets of the population, such as racial minorities or the poor (e.g., Gilens 2012). Finally, our analysis of institutional moderators, though hardly the final word on the subject, suggests little reason for faith in institutional reforms, at least among those that have been widely implemented at the state level, as a means of improving dynamic responsiveness. 


\section{References}

Achen, Christopher H. 1978. "Measuring Representation." American Journal of Political Science 22 (3): 475-510.

Achen, Christopher H., and Larry M. Bartels. 2016. Democracy for Realists: Why Elections Do Not Produce Responsive Government. Princeton, NJ: Princeton UP.

Alesina, Alberto. 1988. "Credibility and Policy Convergence in a Two-Party System with Rational Voters." American Economic Review 78 (4): 796-805.

Alexander, Herbert E., and Laura L. Denny. 1966. Regulation of Political Finance. Berkeley, CA and Princeton, NJ: Institute of Governmental Studies, University of California, Berkeley / Citizens' Research Foundation.

Angrist, Joshua David, and Jörn-Steffen Pischke. 2009. Mostly Harmless Econometrics: An Empiricist's Companion. Princeton, NJ: Princeton University Press.

Ansolabehere, Stephen, James M. Snyder Jr., and Charles Stewart III. 2001. "Candidate Positioning in U.S. House Elections." American Journal of Political Science 45 (1): $136-159$.

Arceneaux, Kevin. 2002. "Direct Democracy and the Link between Public Opinion and State Abortion Policy." State Politics 86 Policy Quarterly 2 (4): 372-387.

Arnold, R. Douglas. 1990. The Logic of Congressional Action. New Haven, CT: Yale University Press.

Bafumi, Joseph, and Michael C. Herron. 2010. "Leapfrog Representation and Extremism: A Study of American Voters and Their Members in Congress." American Political Science Review 104 (3): 519-542. 
Bailey, Michael A. 2007. "Comparable Preference Estimates across Time and Institutions for the Court, Congress, and Presidency." American Journal of Political Science 51, no. 3 (July): 433-448.

Bailey, Michael A, and Mark Carl Rom. 2004. "A Wider Race? Interstate Competition across Health and Welfare Programs." Journal of Politics 66 (2): 326-347.

Barber, Michael J. 2016. "Ideological Donors, Contribution Limits, and the Polarization of American Legislatures." The Journal of Politics 78 (1): 296-310.

Bartels, Larry M. 2008. Unequal Democracy: The Political Economy of the New Gilded Age. Princeton, NJ: Princeton University Press.

Beck, Nathaniel, and Jonathan N. Katz. 2011. "Modeling Dynamics in Time-Series-CrossSection Political Economy Data." Annual Review of Political Science 14:331-352.

Berry, William D., Evan J. Ringquist, Richard C. Fording, and Russell L. Hanson. 1998. "Measuring Citizen and Government Ideology in the American States, 1960-93." American Journal of Political Science 42 (1): 327-348.

Besley, Timothy, and Anne Case. 2003. "Political Institutions and Policy Choices: Evidence from the United States." Journal of Economic Literature 41 (1): 7-73.

Besley, Timothy, and Stephen Coate. 1997. "An Economic Model of Representative Democracy." Quarterly Journal of Economics 112 (1): 85-114.

Brown, Robert D. 1995. "Party Cleavages and Welfare Effort in the American States." American Political Science Review 89 (1): 23-33.

Carmines, Edward G., and James A. Stimson. 1980. "The Two Faces of Issue Voting." American Political Science Review 74 (1): 78-91. 
Caughey, Devin. 2016. "Representation without Parties: Reconsidering the One-Party South, 1930-62." Paper presented at the SPSA Annual Meeting, San Juan, PR, January 8. https : //www . dropbox.com/s/07tkquincbd2d3c/Caughey-RepresentationSouth . $\operatorname{pdf} ? \mathrm{dl}=0$.

Caughey, Devin, Chris Tausanovitch, and Christopher Warshaw. 2017. "Partisan Gerrymandering and the Political Process: Effects on Roll-Call Voting and State Policies." Working paper, May 15. http://cwarshaw.scripts.mit.edu/papers/CTW_efficiency_gap_ 170515.pdf.

Caughey, Devin, and Christopher Warshaw. 2015. "Dynamic Estimation of Latent Opinion Using a Hierarchical Group-Level IRT Model.” Political Analysis 23 (2): 197-211.

— 2016. "The Dynamics of State Policy Liberalism, 1936-2014." American Journal of Political Science 60 (4): 899-913.

Caughey, Devin, Christopher Warshaw, and Yiqing Xu. Forthcoming. "Incremental Democracy: The Policy Effects of Partisan Control of State Government." Journal of Politics.

Clark, Jennifer Hayes, and R Lucas Williams. 2014. "Parties, term limits, and representation in the US states." American Politics Research 42 (1): 171-193.

Dahl, Robert A. 1971. Polyarchy: Participation and Opposition. New Haven, CT: Yale University Press.

—. 1989. Democracy and Its Critics. New Haven, CT: Yale University Press.

De Boef, Suzanna, and Luke Keele. 2008. "Taking Time Seriously." American Journal of Political Science 52 (1): 184-200.

Downs, Anthony. 1957. An Economic Theory of Democracy. New York: Harper \& Row. 
Dunham, James, Devin Caughey, and Christopher Warshaw. 2016. dgo: Dynamic Estimation of Group-Level Opinion. R package version 0.2.3. https://jamesdunham.github.io/ $\operatorname{dgo} /$.

Dye, Thomas R. 1966. Politics, Economics, and the Public: Political Outcomes in the American States. Chicago: Rand McNally.

Enns, Peter K, and Julianna Koch. 2013. "Public Opinion in the U.S. States: 1956 to 2010." State Politics and Policy Quarterly 13 (3): 349-372.

Erikson, Robert S., Michael B. MacKuen, and James A. Stimson. 2002. The Macro Polity. New York: Cambridge University Press.

Erikson, Robert S., Gerald C. Wright, and John P. McIver. 1993. Statehouse Democracy: Public Opinion and Policy in the American States. New York: Cambridge University Press.

—. 2006. "Public Opinion in the States: A Quarter Century of Change and Stability." In Public Opinion in State Politics, edited by Jeffrey E. Cohen, 229-253. Palo Alto, CA: Stanford University Press.

Fearon, James D. 1999. "Electoral Accountability and the Control of Politicians: Selecting Good Types versus Sanctioning Poor Performance." In Democracy, Accountability, and Representation, edited by Adam Przeworski, Susan Carol Stokes, and Bernard Manin. New York: Cambridge University Press.

Feigenbaum, James J., Alexander Fouirnaies, and Andrew B. Hall. Forthcoming. "The Majority Party Disadvantage: Revising Theories of Legislative Organization." Quarterly Journal of Political Science.

Folke, Olle, and James M. Snyder Jr. 2012. "Gubernatorial Midterm Slumps." American Journal of Political Science 56 (4): 931-948. 
Ford, Pamela S. 1955. Regulation of Campaign Finance. Bureau of Public Administration, University of California.

Fowler, Anthony, and Andrew B. Hall. 2016. "The Elusive Quest for Convergence." Quarterly Journal of Political Science 11:131-149.

—. Forthcoming. "Long-Term Consequences of Election Results." British Journal of Political Science. doi:10.1017/S0007123415000241.

Gerber, Elisabeth R. 1996. "Legislative Response to the Threat of Popular Initiatives." American Journal of Political Science: 99-128.

Gilens, Martin. 2012. Affluence and Influence: Economic Inequality and Political Power in America. Princeton, NJ: Princeton UP.

Gray, Virginia, David Lowery, Matthew Fellowes, and Andrea McAtee. 2004. "Public Opinion, Public Policy, and Organized Interests in the American States." Political Research Quarterly 57 (3): 411-420.

Honaker, James, Gary King, and Matthew Blackwell. 2011. "Amelia II: A Program for Missing Data." Journal of Statistical Software 45 (7): 1-47. http://www . jstatsoft. org/v45/i07/.

Hopkins, Daniel J. 2016. "The Increasingly United States." Book manuscript, the University of Pennsylvania.

Jessee, Stephen A. 2009. "Spatial Voting in the 2004 Presidential Election." American Political Science Review 103 (1): 59-81.

Kastellec, Jonathan P., Jeffrey R. Lax, Michael Malecki, and Justin H. Phillips. 2015. "Polarizing the Electoral Connection: Partisan Representation in Supreme Court Confirmation Politics." The Journal of Politics 77 (3): 787-804.

Key, V. O., Jr. 1949. Southern Politics in State and Nation. New York: Knopf. 
Kingdon, John W. 1989. Congressmen's Voting Decisions. Ann Arbor: University of Michigan Press.

-1995. Agendas, Alternatives, and Public Policies. 2nd ed. New York: HarperCollins.

Klarner, Carl. 2013. State Partisan Balance Data, 1937-2011. http://hdl . handle.net/ $1902.1 / 20403$.

Kousser, J. Morgan. 1974. The Shaping of Southern Politics: Suffrage Restriction and the Establishment of the One-Party South. New Haven, CT: Yale University Press.

Kousser, Thad. 2005. Term Limits and the Dismantling of State Legislative Professionalism. New York: Cambridge University Press.

Kousser, Thad, Jeffrey B. Lewis, and Seth E. Masket. 2007. "Ideological Adaptation? The Survival Instinct of Threatened Legislators." Journal of Politics 69 (3): 828-843.

La Raja, Raymond J., and Brian F. Schaffner. 2014. "The Effects of Campaign Finance Spending Bans on Electoral Outcomes: Evidence from the States about the Potential Impact of Citizens United v. FEC." Electoral Studies 33 (March): 102-114.

—. 2015. Campaign Finance and Political Polarization: When Purists Prevail. University of Michigan Press.

Lascher, Edward L., Michael G. Hagen, and Steven A. Rochlin. 1996. "Gun Behind the Door? Ballot Initiatives, State Policies and Public Opinion." Journal of Politics 58 (3): $760-775$.

Lax, Jeffrey R., and Justin H. Phillips. 2009. "Gay Rights in the States: Public Opinion and Policy Responsiveness." American Political Science Review 103 (3): 367-386. . 2012. "The Democratic Deficit in the States." American Journal of Political Science 56 (1): 148-166. 
Lee, David S., Enrico Moretti, and Matthew J. Butler. 2004. "Do Voters Affect or Elect Policies? Evidence from the U. S. House." Quarterly Journal of Economics 119 (3): $807-859$.

Levitt, Steven D. 1996. "How Do Senators Vote? Disentangling the Role of Voter Preferences, Party Affiliation, and Senator Ideology." American Economic Review 86 (3): 425-441.

Maestas, Cherie. 2000. "Professional Legislatures and Ambitious Politicians: Policy Responsiveness of State Institutions." Legislative Studies Quarterly: 663-690.

Matsusaka, John G. 2001. "Problems with a Methodology Used to Evaluate the Voter Initiative." Journal of Politics 63 (4): 1250-1256.

2008. For the Many or the Few: The Initiative, Public Policy, and American Democracy. Chicago: University of Chicago Press.

—. 2010. "Popular Control of Public Policy: A Quantitative Approach." Quarterly Journal of Political Science 5 (2): 133-167.

Mayhew, David R. 1974. Congress: The Electoral Connection. New Haven, CT: Yale UP.

McGann, Anthony J. 2014. "Estimating the Political Center from Aggregate Data: An Item Response Theory Alternative to the Stimson Dyad Ratios Algorithm." Political Analysis 22 (1): $115-129$.

Mickey, Robert W. 2015. Paths Out of Dixie: The Democratization of Authoritarian Enclaves in America's Deep South. Princeton, NJ: Princeton UP.

Miller, Warren E., and Donald E. Stokes. 1963. "Constituency Influence in Congress." American Political Science Review 57 (1): 45-56.

Monogan, James, Virginia Gray, and David Lowery. 2009. "Public Opinion, Organized Interests, and Policy Congruence in Initiative and Noninitiative US States." State Politics 83 Policy Quarterly 9 (3): 304-324. 
Nickell, Stephen. 1981. "Biases in Dynamic Models with Fixed Effects." Econometrica 49:14171426.

Oates, Wallace E. 1972. Fiscal Federalism. New York: Harcourt Brace Jovanovich.

Pacheco, Julianna. 2011. "Using National Surveys to Measure Dynamic U.S. State Public Opinion: A Guideline for Scholars and an Application." State Politics $\&$ Policy Quarterly $11(4): 415-439$.

. 2013. "The Thermostatic Model of Responsiveness in the American States." State Politics 8 Policy Quarterly 13 (3): 306-332.

Page, Benjamin, and Robert Shapiro. 1983. "Effects of Public Opinion on Policy." American Political Science Review 77 (1): 175-190.

1992. The Rational Public: Fifty Years of Trends in Americans'Policy Preferences. Chicago: University of Chicago.

Pew Charitable Trusts. 2016. Fact Sheet: Share of States'Budgets From Federal Grants Stabilizes, August 29. Accessed November 21, 2016. http://www .pewtrusts.org/en/ research-and-analysis/fact-sheets/2016/08/share-of-states-budgets-fromfederal-grants-stabilizes.

Poole, Keith T. 2007. "Changing Minds? Not in Congress!" Public Choice 131 (3): 435-451.

Poole, Keith T., and Howard Rosenthal. 1984. "The Polarization of American Politics." Journal of Politics 46 (4): 1061-1079.

- 2007. Ideology $\&$ Congress. New Brunswick, NJ: Transaction Publishers.

Przeworski, Adam, Susan Carol Stokes, and Bernard Manin. 1999. "Introduction." In Democracy, Accountability, and Representation, edited by Adam Przeworski, Susan Carol Stokes, and Bernard Manin. New York: Cambridge University Press. 
Quinn, Kevin M. 2004. "Bayesian Factor Analysis for Mixed Ordinal and Continuous Responses." Political Analysis 12 (4): 338-353.

Ringquist, Evan J., and James C. Garand. 1999. "Policy Change in the American States." In American State and Local Politics: Directions for the 21st Century, edited by Ronald E. Weber and Paul Brace, 268-99. New York: Chatham House: Seven Bridges Press.

Rogers, Steven. 2016. "National Forces in State Legislative Elections." ANNALS of the American Academy of Political and Social Science 667 (September): 207-225.

Ruggles, Steven, J. Trent Alexander, Katie Genadek, Ronald Goeken, Matthew B. Schroeder, and Matthew Sobek. 2010. Integrated Public Use Microdata Series: Version 5.0 [Machinereadable database]. Minneapolis: University of Minnesota.

Shor, Boris, and Nolan McCarty. 2011. "The Ideological Mapping of American Legislatures." American Political Science Review 105 (3): 530-51.

Snyder, James M., Jr., and Michael M. Ting. 2003. "Roll Calls, Party Labels, and Elections." Political Analysis 11 (4): 419-444.

Soroka, Stuart, and Christopher Wlezien. 2010. Degrees of Democracy: Politics, Public Opinion, and Policy. New York: Cambridge Univ Press.

Springer, Melanie Jean. 2014. How the States Shaped the Nation: American Electoral Institutions and Voter Turnout, 1920-2000. Chicago: University of Chicago Press.

Squire, Peverill. 1992. "Legislative Professionalization and Membership Diversity in State Legislatures." Legislative Studies Quarterly: 69-79.

—. 2007. "Measuring State Legislative Professionalism: The Squire Index Revisited." State Politics \&6 Policy Quarterly 7 (2): 211-227.

Stimson, James A. 1991. Public Opinion in America: Moods, Cycles, and Swings. Boulder, CO: Westriew. 
Stimson, James A. 2009. "Perspectives on Unequal Democracy: The Political Economy of the New Gilded Age." Perspectives on Politics 7 (1): 151-153.

Stimson, James A., Michael B. MacKuen, and Robert S. Erikson. 1995. "Dynamic Representation." American Political Science Review 89 (3): 543-565.

Stimson, James A., Cyrille Thiébaut, and Vincent Tiberj. 2012. "The Evolution of Policy Attitudes in France." European Union Politics 13 (2): 293-316.

Stratmann, Thomas, and Francisco J. Aparicio-Castillo. 2006. "Competition Policy for Elections: Do Campaign Contribution Limits Matter?" Public Choice 127 (1): 177-206.

Tanner, Martin A. 1996. Tools for Statistical Inference Methods for the Exploration of Posterior Distributions and Likelihood Functions. 3rd ed. New York: Springer.

Tausanovitch, Chris, and Christopher Warshaw. 2013. "Measuring Constituent Policy Preferences in Congress, State Legislatures and Cities." Journal of Politics 75 (2): 330342.

Treier, Shawn, and D. Sunshine Hillygus. 2009. "The Nature of Political Ideology in the Contemporary Electorate." Public Opinion Quarterly 73 (4): 679-703.

Treier, Shawn, and Simon Jackman. 2008. "Democracy as a Latent Variable." American Journal of Political Science 52 (1): 201-217.

Weissberg, Robert. 1978. "Collective vs. Dyadic Representation in Congress." American Political Science Review 72 (2): 535-547.

Werner, Timothy, and John J. Coleman. 2013. "Assessing the Potential Effects of Citizens United: Policy and Corporate Governance in the States." Paper prepared for the Meeting of the Public Choice Society, New Orleans, LA. http://users.polisci.wisc.edu/ coleman/wernercolemanpcs2013.pdf. 


\section{Supplementary Information for "Policy Preferences and Policy Change: \\ Dynamic Responsiveness in the American States, 1936-2014"}

A Measurement Model for Citizen Policy Liberalism

B Validation of Citizen Policy Liberalism Estimates

C Summary Statistics for Key Independent Variables

D Methodology for Addressing Measurement Error

E Robustness to Differential Sample Sizes Across Time

F Alternative Dynamic Specifications

G Effect of Individual Institutions on Responsiveness

H Survey Questions for Mass Liberalism Models 


\section{A Measurement Model for Citizen Policy Liberalism}

The lack of a valid, time-varying measure of citizen policy liberalism has been one of the main barriers to the study of responsiveness in the American states. As a result, studies of state politics have overwhelmingly relied on proxies for public opinion such as ideological self-identification (Erikson, Wright, and McIver 1993), presidential vote (Shor and McCarty 2011), or the roll-call records of the state congressional delegation (Berry et al. 1998).

To overcome this challenge, we estimate the latent policy liberalism of state publics in every year between 1936 and 2014 by aggregating responses to many distinct policy questions across many polls. ${ }^{32}$ We estimate citizen policy liberalism using the statistical framework of item-response theory (e.g., Tausanovitch and Warshaw 2013). In the twoparameter IRT model, the relationship between responses to question $q$ and the unobserved trait $\theta_{i}$ is governed by the question's threshold $\kappa_{q t}$, which captures the base level of support for the question, and its dispersion $\sigma_{q}$, which represents question-specific measurement error. Under this model, respondent $i$ 's probability of selecting the liberal response to question $q$ is:

$$
\pi_{i q}=\Phi\left(\frac{\theta_{i}-\kappa_{q t}}{\sigma_{q}}\right)
$$

where the normal CDF $\Phi$ maps $\left(\theta_{i}-\kappa_{q t}\right) / \sigma_{q}$ to the $(0,1)$ interval. ${ }^{33}$ The model assumes that greater liberalism (i.e., higher values of $\theta_{i}$ ) increases respondents' probability of answering liberally. The strength of this relationship is inversely proportional to $\sigma_{q}$, and the threshold for a liberal response is governed by $\kappa_{q t}$.

Accurate estimation of $\theta_{i}$ requires data from many respondents, each of whom answers

32. Our approach bears a close relation to the literature on "public policy mood" (Stimson 1991). Works in this tradition use Stimson's Dyad Ratios algorithm to estimate changes in public preferences for government activity (i.e., left-liberalism). Recently, Enns and Koch (2013) have combined the Dyad Ratios algorithm with MRP to generate state-level estimates of policy mood. As McGann (2014) observes, though, the Dyad Ratios algorithm has several unappealing features, most notably its ideological asymmetry and its lack of a grounding in a coherent individual-level model. As an alternative, he proposes a group-level IRT model for national mood that is similar to the approach we take. However, our dynamic group-level IRT model, accommodates cross-sectional and over-time variation within a common framework.

33. A common alternative way of writing the model in Equation (1) is $\operatorname{Pr}\left(y_{i q}=1\right)=\Phi\left(\beta_{q} \theta_{i}-\alpha_{q}\right)$, where $\beta_{q}=1 / \sigma_{q}$ and $\alpha_{q}=\kappa_{q t} \times \beta_{q}$. 
many items (Lewis 2001, 277). Prior to the 2000s, however, few surveys included more than a handful of policy questions, and those questions that were included were rarely asked in consistent form across many years. The fact that each respondent answers no more than a few questions (sometimes only one) prevents us from using an IRT model to estimate the liberalism of individual respondents. Our ultimate interest, however, is not individuals but rather the average citizen liberalism in each group (e.g., state-year). Fortunately, as Bailey (2001), Lewis (2001), and others have noted, it is possible to make inferences about the average level of $\theta_{i}$ in each group even when individual-level estimation is not feasible.

Following Caughey and Warshaw (2015), we do this by treating individual citizens as having been randomly sampled from a given subpopulation $g$ defined by demographic and geographic characteristics (e.g., rural, white Alabamans). Assuming that $\theta_{i[g]}$ is distributed normally with mean $\bar{\theta}_{g}$ and standard deviation $\sigma_{\theta}$, we can re-write the individual-level IRT model at the group level as

$$
p_{g j}=\Phi\left(\frac{\bar{\theta}_{g}-\kappa_{j}}{\sqrt{\sigma_{j}^{2}+\sigma_{\theta}^{2}}}\right)
$$

where $p_{g j}$ is the probability that a randomly sampled citizen from group $g$ will give a liberal answer to item $j$ (Mislevy 1983). We then model group $g$ 's total number of liberal answers to item $j$ as

$$
s_{g j} \sim \operatorname{Binomial}\left(n_{g j}, p_{g j}\right)
$$

where $n_{g q}$ is group $g$ 's total number of non-missing responses to question $j$ and $s_{g j}$ is the number of those responses that are liberal. ${ }^{34}$ The estimates of $\bar{\theta}_{g}$ may be of interest in themselves, or they can be poststratified into estimates of, for example, average liberalism in each state (cf. Park, Gelman, and Bafumi 2004).

\footnotetext{
34. Following Ghitza and Gelman (2013) and Caughey and Warshaw (2015, 202-3), we adjust the raw values of $s_{g q}$ and $n_{g q}$ to account for survey weights and for respondents who answer multiple questions. The latter is particularly important in this application because of the way that we deal with ordinal questions, which is to break each such question into a set of dichotomous questions, each of which indicates whether the response is above a given response level. For example, a question with three ordinal response choices, (1) "disagree", (2) "neutral", and (3) "agree," would be converted into two dichotomous variables respectively indicating whether the response is above "disagree" and above "neutral."
} 
Even with our large-scale dataset of survey respondents, many group cells are likely to be small or empty in a given year. To address this sparseness, we use a dynamic linear model to smooth the estimated group means across both time and states. Letting $\xi_{t}$ be an intercept common to all groups and $\boldsymbol{x}_{g}$. a vector of hierarchical predictors (Race, Urban, and State), we model the group means in each year as

$$
\bar{\theta}_{g t} \sim N\left(\delta_{t} \bar{\theta}_{g, t-1}+\xi_{t}+\mathbf{x}_{g}^{\prime} \cdot \gamma_{t}, \sigma_{\bar{\theta} t}^{2}\right),
$$

That is, the prior expected value for $\bar{\theta}_{g t}$ is a weighted combination of its lagged value and predictions based on demographically similar groups, with the variance of the prior determined by $\sigma_{\bar{\theta}}^{2}$. If there are no survey responses from group $g$ in year $t,(4)$ acts as an imputation model for the missing data. Mean citizen liberalism in each state can be estimated by poststratifying the group estimates to match groups' proportions of the population (Park, Gelman, and Bafumi 2004).

To estimate mass liberalism on the economic and social domains, we rely on a dataset of survey responses to over 300 domestic policy questions spread across nearly 1,000 publicopinion surveys fielded between 1936 and 2014. The economic questions cover issues such as taxes, social welfare, and labor regulation. The social questions include ones about alcohol, abortion, gay rights, women's rights, school prayer, and other cultural (but not racial) issues. In order to ensure the comparability of our estimates over time, we use question series with consistent question wording, substantive meaning, and response categories as bridge items. ${ }^{35}$ While no individual survey item is asked consistently between 1936 and 2014, there are many survey questions that are asked consistently for shorter periods of time. These items glue our estimates from one time period together with our estimates for other time periods. Since almost all these surveys also include a question about party identification, we use the same dataset to estimate the proportions of Democrats, Republicans, and Independents in each

35. We generally do not include "relative" questions about whether the government should do more since these questions are not comparable longitudinally due to changes in the policy status quo. In the few cases where we include relative questions, we code them as separate questions in each year. 
state year.

Overall, the responses of approximately 1.5 million distinct individuals are represented in the data. ${ }^{36}$ We use the dynamic group-level IRT model described above to estimate average liberalism in groups defined by state, race, and urban residence. ${ }^{37}$ To generate annual estimates of average opinion in each state, we poststratified the group estimates to match the groups' proportions in the state population, based on data from the U.S. Census (Ruggles et al. 2010). Finally, we standardized the citizen liberalism estimates in order to make them easier to interpret.

36. The model of social policy liberalism includes 801,372 respondents from 485 individual polls that were asked 72 distinct policy questions. The model of economic policy liberalism includes 1,199,876 respondents from 779 polls that were asked 285 distinct policy questions.

37. We also raked the survey data to match interpolated targets for gender and education level in each state public, based on microdata from the U.S. Census (Ruggles et al. 2010). In order to mitigate sampling error for small states, we model the state effects in the first time period as a function of state Proportion Evangelical/Mormon. The inclusion of state attributes in the model partially pools information across similar geographical units in the first time period, improving the efficiency of state estimates (e.g., Park, Gelman, and Bafumi 2004). We drop Proportion Evangelical/Mormon after the first period because we found that the state intercept in the previous period tends to be much more predictive than state attributes. We estimate the dynamic, hierarchical group-level IRT model using the dgo package in R (Dunham, Caughey, and Warshaw 2016). 


\section{B Validation of Citizen Policy Liberalism Estimates}

In this section, we provide evidence for the validity of our measures of citizen policy liberalism with two kinds of validation: convergent and construct (Adcock and Collier 2001). The purpose of convergent validation is to show that a new measure is empirically associated with alternative measures of the same concept. We do this by comparing our liberalism estimates with alternative estimates of the mass public's ideology or mood. We then turn to construct validation, the goal of which is demonstrate the empirical association between a new measure of a given concept and existing measures of different concepts widely believed to be causally related to the concept of interest. We do this by evaluating the relationship between our estimates and presidential vote share, state government policy liberalism, and the median ideology of state legislators.

In addition to showing the validity of our estimates of mass citizen liberalism, we also show that our estimates have stronger convergent and concept validity than the main alternative, dynamic measures of the mass public's ideology at the state level that are available over a long period of time. First, we compare our measures to the citizen ideology estimates of Berry et al. (1998), which are available from 1960-2013 and are based on a weighted average of the scaled roll call votes of elected officials. ${ }^{38}$ Next, we compare our measures to the statelevel mood estimates of Enns and Koch (2013), which are available from 1956-2008 and are based on a combination of Stimson's mood algorithm and multi-level regression with poststratification (MRP) ${ }^{39}$ Finally, we compare our estimates to the symbolic ideology estimates from Pacheco (2014). These estimates are available from 1978-2010 and are based on the application of an MRP model to a moving window of symbolic ideology data from CBS/NY Times polls during this period.

38. There is a vigorous debate in the literature about the appropriateness of using these measures to estimate mass liberalism. Critics worry that they lack face validity and display overly volatile longitudinally (Erikson, Wright, and McIver 2007; Enns and Koch 2015).

39. There is also a debate about the validity of these measures between Berry et al. (2015) and Enns and Koch (2015). 


\section{Convergent Validation}

The purpose of convergent validation is to show that a new measure is empirically associated with alternative measures of the same concept (Adcock and Collier 2001). Here, we show that our measures of the mass public's liberalism are very highly correlated with high-quality measures of ideology that are available for recent decades. In addition, we show that they have a stronger relationship with these measures of ideology than the alternative dynamic ideology measures that are available over a long period of time.

Table A1 shows the percentage of the variation in a number of high-quality cross-sectional measures of ideology explained by the available dynamic measures of mass liberalism. ${ }^{40}$ First, we examine each measure of mass liberalism's relationship with state-level estimates of symbolic ideology derived from exit polls. ${ }^{41}$ Exit polls have large samples in each state, which enables us to relatively precisely capture cross-state variation. ${ }^{42}$ The main disadvantage of using exit polls is that their population frame is slightly different from our estimates: they focus on voters rather than general population. In addition, state exit polls are only available going back to 1984 . Our measure of mass liberalism explains $75 \%$ of the variation in the ideological composition of state electorates in exit polls. Moreover, it has a stronger correlation with exit poll-based measures of ideology than the alternative measures of mass liberalism. The Enns and Koch (2013) estimates display a particularly weak relationship with exit polls.

Next, we examine each dynamic ideology measure's relationship with measures of symbolic ideology derived from CBS/NY Times polls between 1976-2003 (Erikson, Wright, and McIver 2006). These polls have been widely used in past work as measures of state publics' ideologies. The main disadvantage of these measures is that they sometimes have small sam-

40. Each model also includes year fixed effects to account for idiosyncratic over time variation.

41. While symbolic ideology is not exactly the same concept as operational (or policy) ideology, they are very similar concepts.

42. To further reduce sampling error in the exit polls, we only include state/years with more than 200 exit poll respondents in our analysis. 
Table A1: Global Convergent Validation: The table shows the percentage of the variation in a number of high-quality cross-sectional measures of ideology explained by the available dynamic measures of mass liberalism.

\begin{tabular}{lcc|cccc}
\hline & \multicolumn{3}{c}{ Symbolic Ideology Measures } & \multicolumn{3}{c}{ Cross-Sectional Ideology Measures } \\
\hline & $\begin{array}{c}\text { Exit } \\
\text { Polls } \\
\left(' 84-^{-10}\right)\end{array}$ & $\begin{array}{c}\text { CBS } \\
\text { News } \\
(' 76-' 03)\end{array}$ & EWM & $\begin{array}{c}\text { Tausanovitch } \\
\text { \& Warshaw } \\
\end{array}$ & $\begin{array}{c}\text { Carsey } \\
\text { \& Harden } \\
(2008)\end{array}$ & $\begin{array}{c}\text { Lax } \\
\text { \& Phillips } \\
(2010)\end{array}$ \\
\hline Our measures of Mass Liberalism & 0.74 & 0.61 & 0.70 & 0.90 & 0.78 & 0.87 \\
Fording et al (state ideology) & 0.67 & 0.53 & 0.60 & 0.71 & 0.58 & 0.79 \\
Enns and Koch (state mood) & 0.34 & 0.20 & 0.01 & 0.31 & 0.43 & 0.39 \\
Pacheco (state ideology) & 0.62 & 0.63 & 0.48 & 0.73 & 0.65 & 0.72 \\
\hline
\end{tabular}

ple sizes in individual states. ${ }^{43}$ Once again, our measures explain much more of the variation in the CBS/NY Times based measures of ideology than Berry et al. (1998) and Enns and Koch (2013). The measures from Pacheco (2014) have a slightly stronger relationship with the CBS polls, but this isn't surprising since the CBS polls constitute the raw data for her MRP-based measures.

Finally, the right panel of A1 examines the relationship between each measure of mass liberalism and several static, cross-sectional measures of ideology based on survey data from the past decade. Each of these measures are widely used in applied work on representation and elections. For each analysis, we use the year from the dynamic estimates that corresponds most closely to the cross-sectional estimates.

We begin by investigating the dynamic measures' relationship with the cross-sectional estimates of state-level ideology in the 1970s and 1980s from Erikson, Wright, and McIver (1993). ${ }^{44}$ Then, we examine the relationship with ideology measures from the period between 2000-2010 from Tausanovitch and Warshaw (2013). ${ }^{45}$ We also examine each measures' relationship with the estimates of state-level mood from 2008 from Carsey and Harden (2010). ${ }^{46}$

43. To reduce sampling error in these polls, we only include state/years with more than 200 respondents in our analysis.

44. These are based on pooling the symbolic ideology questions on CBS News/NY Times polls during this period.

45. These are based on the combination of an Item-response theory (IRT) model to measure ideology at the individual level and an MRP model to smooth opinion across states. Their model draws upon over 250,000 survey respondents from the 2000 and 2004 Annenberg National Election Surveys and the 2006-2010 Cooperative Congressional Election Studies.

46. These are based on the combination of a factor analysis model to estimate individual ideology using data from the 2006 Cooperative Congressional Election Study. 
Finally, we compare each measure with the average of the issue-specific preferences in Lax and Phillips (2012). In each case, our measures explain the bulk of the variation in these static measures of ideology (70\% or greater). Moreover, they have a much stronger association with these static measures of ideology than the alternative, dynamic measures of ideology.

Another convergent validation approach is to compare the ideology measures with raw survey data on specific domains. In Table A2, we compare the proportion of the variation in survey data on salient social and economic issues in four discrete time periods that is explained by each measure of ideology. For the social policy domain, we examine the relationship between each measure and state-level opinion on a ban on alcohol around 1950. For later time periods, we examine survey questions on abortion. For the economic domain, we examine the relationship between each measure and the average response in each state to surveys on universal healthcare.

Once again, our measure performs particularly well. In all four time periods, and on both the economic and social domains, it explains the bulk of the variation in the raw survey data. In contrast, the alternative measures sometimes perform reasonably well in the most recent time period, but generally perform poorly in earlier time periods (and are completely unavailable in the earliest time period).

Table A2: Domain-Specific Convergent Validation with Individual Survey Questions (CrossSectional): The table shows the percentage of the variation in a number of individual survey items during a variety of time periods that are explained by the available dynamic measures of mass liberalism.

\begin{tabular}{|c|c|c|c|c|c|c|c|c|}
\hline \multirow{4}{*}{$\begin{array}{l}\text { Issue: } \\
\text { Time Range: } \\
\text { Source: }\end{array}$} & \multicolumn{4}{|c|}{ Social Domain } & \multicolumn{4}{|c|}{ Economic Domain } \\
\hline & \multirow{3}{*}{$\begin{array}{c}\text { Ban Alcohol } \\
1947-52 \\
\text { Gallup }\end{array}$} & \multicolumn{3}{|c|}{ Abortion } & \multicolumn{4}{|c|}{ Universal Healthcare } \\
\hline & & 1975-95 & 2000 & 2009-11 & $1949-51$ & 1975-95 & 2000 & 2009-11 \\
\hline & & Various & NAES & CCES & Gallup & Various & NAES & CCES \\
\hline Our measure of Mass Social Liberalism & 0.88 & 0.71 & 0.69 & 0.89 & & & & \\
\hline Our measure of Mass Economic Liberalism & & & & & 0.66 & 0.56 & 0.69 & 0.73 \\
\hline Fording et al (state ideology) & & 0.36 & 0.40 & 0.65 & & 0.36 & 0.32 & 0.67 \\
\hline Enns and Koch (state mood) & & 0.28 & 0.17 & 0.45 & & 0.44 & 0.45 & 0.24 \\
\hline Pacheco (state ideology) & & 0.61 & 0.42 & 0.72 & & 0.38 & 0.38 & 0.49 \\
\hline
\end{tabular}




\section{Construct Validation}

Next, we examine the construct validity of our measures of mass liberalism. The purpose of construct validation is to demonstrate that a measure conforms to well-established hypotheses relating the concept being measured to other concepts (Adcock and Collier 2001, $542-3)$.

The left two columns of Table A3 examine the percentage of the variation between each dynamic measure of mass ideology and Democrats' presidential vote share. While presidential election results are not a perfect measure of citizens' policy preferences (Levendusky, Pope, and Jackman 2008; Kernell 2009), a variety of previous scholars have used presidential election returns to estimate state and district preferences (Ansolabehere, Snyder, and Stewart 2001; Canes-Wrone, Brady, and Cogan 2002). Thus, to the extent that policy attitudes predict presidential partisanship, a high correlation with Democratic presidential vote share would suggest that our estimates are accurate measures of states' policy preferences. The table shows that our measures explain much of the state-level variation in presidential vote share. Figures A1 and A2 show the year-by-year relationship between our estimates of mass policy liberalism and presidential vote share between 1936 and 2012 in non-southern states. It indicates that the relationship is strong across the period, but the relationship between ideology and presidential vote increases in strength over time, mirroring the growing alignment of policy preferences with partisanship and presidential voting at the individual level (Fiorina and Abrams 2008, 577-82). Finally, Table A3 shows that our measure has a stronger relationship with presidential vote than the other available measures of mass liberalism.

The right two columns of Table A3 show the relationship between our measure (as well as the other available ideology measures) with two other concepts that should be associated with mass liberalism: state policy (Caughey and Warshaw 2016) and the median ideal point in the state house house (Shor and McCarty 2011). In both cases, our measure of mass liberalism explains much of the variation in these theoretically related measures. Moreover, it has a higher correlation with them than the other available dynamic measures of mass 
ideology.

Table A3: Concept Validation: The table shows the percentage of the variation in a number of concepts that are theoretically related to ideology that are explained by the available dynamic measures of mass liberalism.

\begin{tabular}{lcccc}
\hline & $\begin{array}{c}\text { Presidential Vote } \\
(1960-2008) \\
\text { All States }\end{array}$ & $\begin{array}{c}\text { State Policy Liberalism } \\
\text { Non-South }\end{array}$ & $\begin{array}{c}\text { Median Ideal Point in } \\
\text { Caughey \& Warshaw }\end{array}$ & $\begin{array}{c}\text { State House (1994-2010) } \\
\text { Shor \& McCarty }\end{array}$ \\
\hline \hline Our measures of Mass Liberalism (1956-2010) & 0.67 & 0.75 & 0.60 & 0.50 \\
Fording et al (1956-2010) & 0.61 & 0.74 & 0.55 & 0.4 \\
Enns and Koch (1956-2010) & 0.50 & 0.57 & 0.11 & 0.26 \\
Our measures of Mass Liberalism (1978-2010) & 0.73 & 0.77 & 0.66 & 0.50 \\
Pacheco (1978-2010) & 0.57 & 0.59 & 0.56 & 0.4 \\
\hline
\end{tabular}




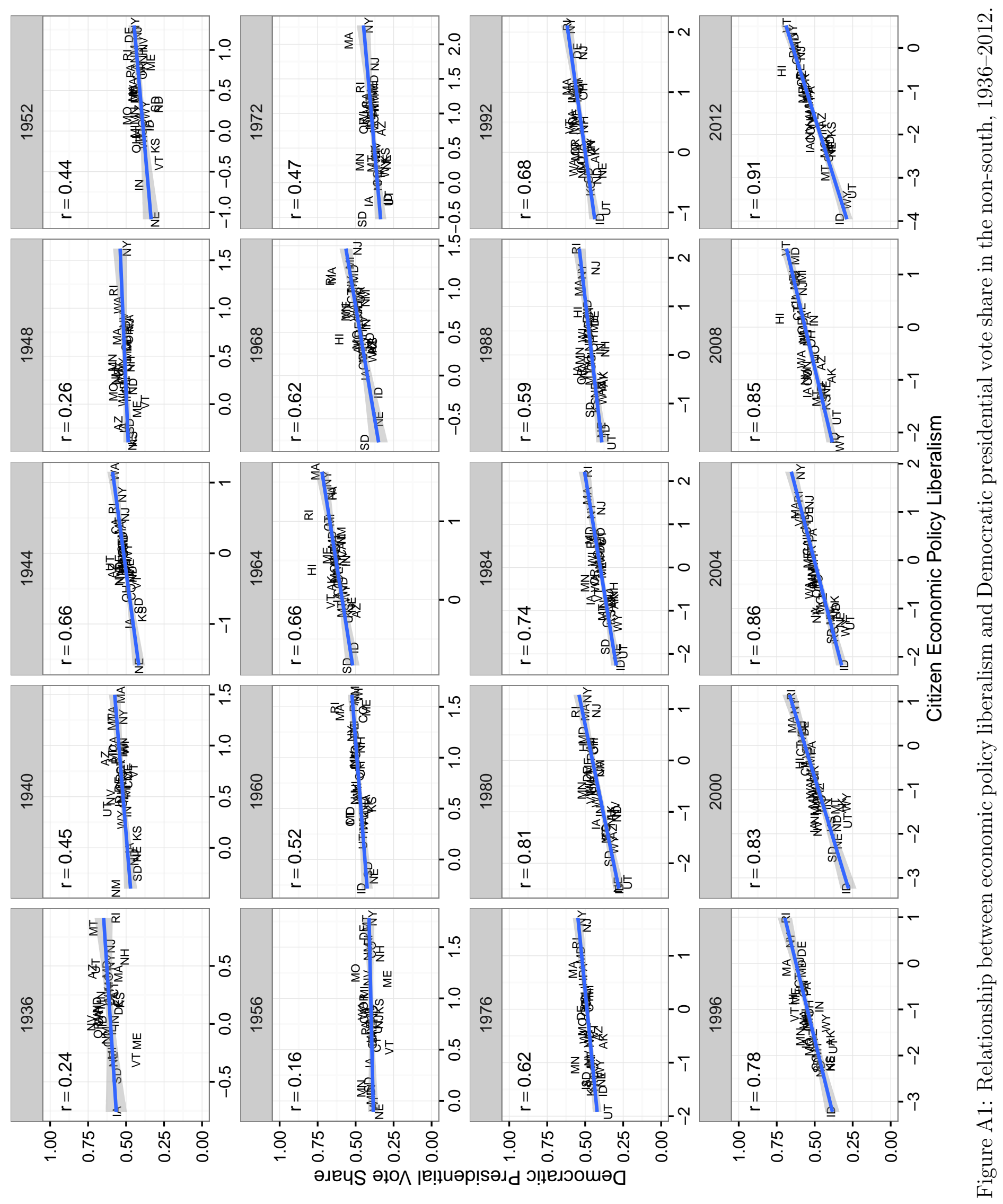




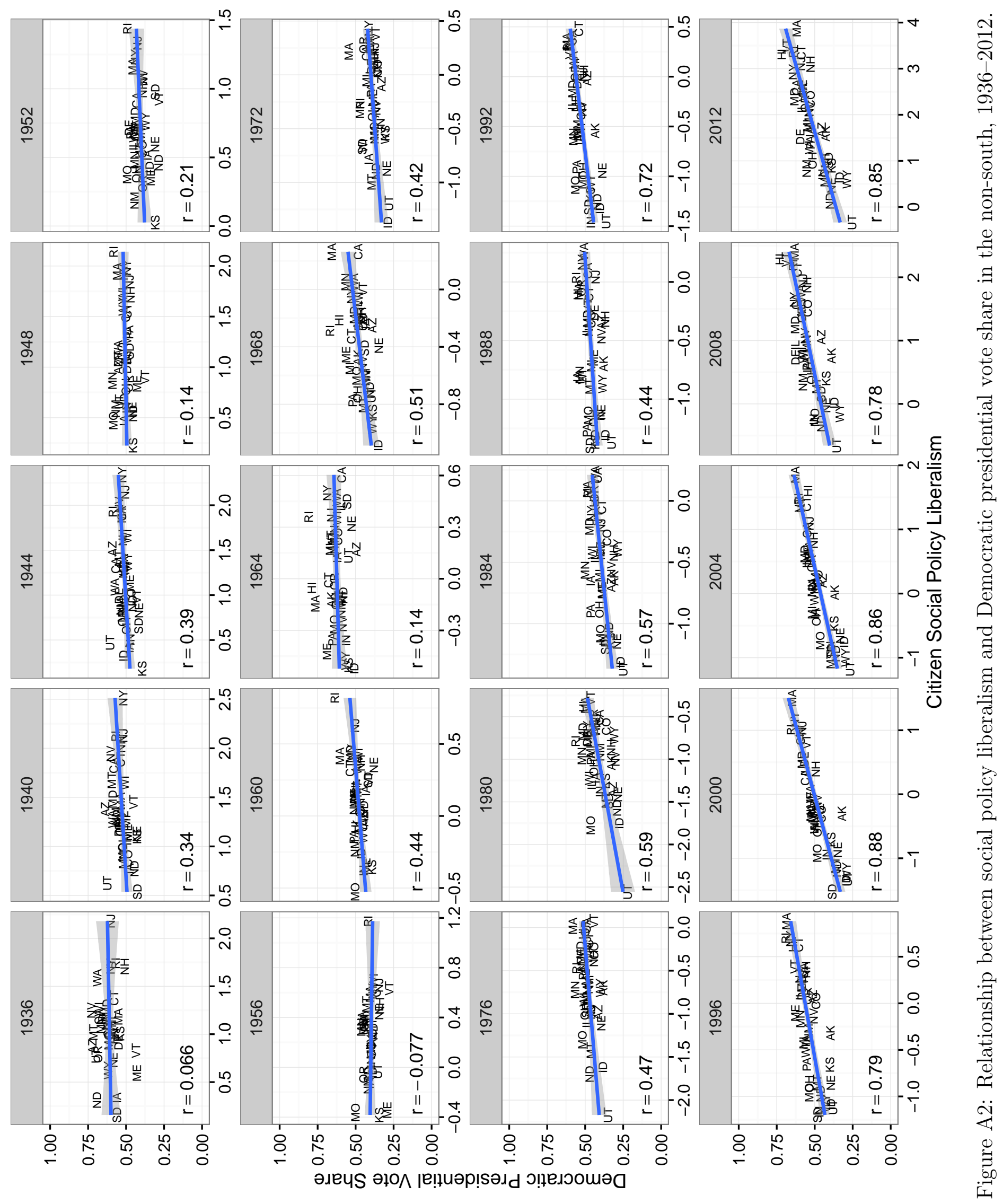




\section{Summary Statistics for Key Independent Variables}

Table A4 shows summary statistics for our key independent variables.

Table A4: Summary Statistics of the Main Variables.

\begin{tabular}{lrrrrr}
\hline \hline Variable & $\mathrm{N}$ & Mean & St. Dev. & Min & Max \\
\hline Social Policy Liberalism & 3,904 & 0.00 & 1.00 & -2.90 & 3.12 \\
Economic Policy Liberalism & 3,904 & 0.00 & 1.00 & -2.36 & 3.32 \\
Mass Social Liberalism & 3,950 & 0.00 & 1.00 & -2.56 & 5.01 \\
Mass Economic Liberalism & 3,950 & 0.00 & 1.00 & -4.21 & 2.76 \\
Democratic PID & 3,450 & 0.00 & 1.00 & -2.08 & 4.23 \\
Democratic Control & 3,678 & 0.58 & 0.39 & 0.00 & 1.00 \\
\hline
\end{tabular}




\section{Methodology for Addressing Measurement Error}

The key independent and dependent variables in this study - mass liberalism and policy liberalism in each issue domain - are latent quantities whose values must be inferred rather than directly observed. As such, they are subject to measurement error. Even if it is independent and mean-zero, measurement error can bias point estimates and standard errors. However, since we can estimate the values' measurement error from their Monte Carlo sampling distributions, we can account for measurement error using a technique known as the "method of composition" (MOC) or "propagated uncertainty" (Tanner 1996, 52; Treier and Jackman 2008, 215-6; Kastellec et al. 2015, 791-2).

The idea behind MOC is that we wish to estimate the marginal distribution (i.e., the posterior or, given flat priors, likelihood) of a parameter vector $\boldsymbol{\beta}$, intergrating over the measurement error in variables $\boldsymbol{X}$ :

$$
p(\boldsymbol{\beta} \mid \boldsymbol{W})=\int_{X} p(\boldsymbol{\beta} \mid \boldsymbol{W}, \boldsymbol{X}) p(\boldsymbol{X} \mid \boldsymbol{Z}) d \boldsymbol{X}
$$

where $\boldsymbol{W}$ is a matrix of variables measured without error and $\boldsymbol{X}$ is a matrix of variables estimated with error conditional on data $\boldsymbol{Z}$ (and a measurement model). That is, we wish to intergrate the joint density of $\boldsymbol{\beta}$ and $\boldsymbol{X}$ over the distribution of $\boldsymbol{X}$. As Treier and Jackman (2008, 215) explain, this can be done via the following iterative procedure: At each iteration $s$,

1. Sample $\boldsymbol{X}^{(s)}$ from the distribution $p(\boldsymbol{X} \mid \boldsymbol{Z})$.

2. Sample $\tilde{\boldsymbol{\beta}}^{(s)}$ from $p\left(\boldsymbol{\beta} \mid \boldsymbol{W}, \boldsymbol{X}^{(s)}\right)$ in two steps:

(a) Conditional on $\boldsymbol{W}$ and $\boldsymbol{X}^{(s)}$, estimate the parameter vector $\hat{\boldsymbol{\beta}}^{(s)}$ and its variancecovariance matrix $\hat{\boldsymbol{V}}^{(s)}$.

(b) Draw one sample $\tilde{\boldsymbol{\beta}}^{(s)}$ from a multivariate normal distribution with mean vector $\hat{\boldsymbol{\beta}}^{(s)}$ and variance-covariance matrix $\hat{\boldsymbol{V}}^{(s)}$. 


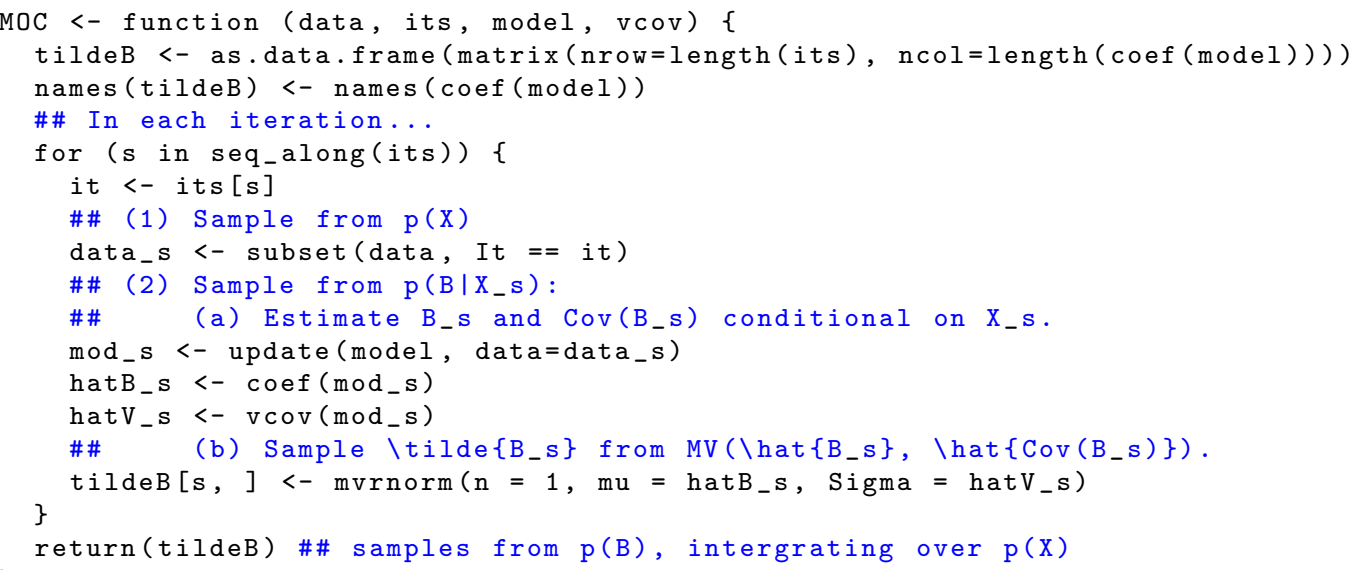

Listing 1: R Function for the Method of Composition

Each draw $\tilde{\boldsymbol{\beta}}^{(s)}$ is a sample from (the normal approximation of) the marginal distribution $p(\boldsymbol{\beta} \mid \boldsymbol{W})$, with the iterative algorithm performing the intergration over $p(\boldsymbol{X} \mid \boldsymbol{Z}) .{ }^{47}$ The $\mathrm{R}$ function we used to implement the MOC algorithm is reproduced in Listing 1.

Using this approach, we accounted for measurement error in four variables: Mass Social Liberalism, Mass Economic Liberalism, Social Policy Liberalism, and Economic Policy Liberalism. Independently for each measure, we drew 500 samples from the joint posterior distribution of state-year values. We combined each four-variable sample with a copy of the other variables in our dataset, which were presumed to be measured without error. Then, following the algorithm above, we re-estimated each model on the 500 versions of the dataset and drew 500 samples of the model parameters. We then used these samples to calculate point estimates and standard errors, on which we based our inferences. Generally, the MOC point estimates for the effect of mass liberalism on policy liberalism were about two-thirds as large as the non-MOC estimates, but the standard errors were about the same size.

47. Treier and Jackman $(2008,216)$ note that this procedure relies on two conditional independence assumptions. The first is that the data used to estimate the latent variables $\boldsymbol{X}$ do not supply information about the model parameters $\boldsymbol{\beta}$ except through $\boldsymbol{X}$. That is, $p(\boldsymbol{\beta} \mid \boldsymbol{W}, \boldsymbol{X})=p(\boldsymbol{\beta} \mid \boldsymbol{W}, \boldsymbol{X}, \boldsymbol{Z})$. The second assumption is that inferences about each latent variable $\boldsymbol{x}_{j}$ are not informed by the other latent variables $\boldsymbol{X}_{-j}$ or by the manifest variables $\boldsymbol{W}$. That is, $p\left(\boldsymbol{x}_{j} \mid \boldsymbol{Z}\right)=p\left(\boldsymbol{x}_{j} \mid \boldsymbol{Z}, \boldsymbol{X}_{-j}, \boldsymbol{W}\right)$. Together, these assumptions separate the estimation of the measurement model from the estimation of the structural model. 


\section{E Robustness to Differential Sample Sizes Across Time}

A possible concern about our finding of increased responsiveness over time is that it may be the spurious consequence of differential measurement error across time. Specifically, one might suspect that the seemingly weaker responsiveness in earlier eras is driven by the fact that the frequency of polling has increased over time, and thus public opinion in recent decades is simply better measured. This concern is partially addressed by our use of MOC to account for measurement error. Indeed, as long as we are correctly characterizing the uncertainty in our measures, the MOC procedure should fully account for any spurious effects of measurement error. One thing that MOC cannot account for, however, is that the "weight" our measurement model give to different years depends on the sample size in those years. If survey respondents are more numerous later in the period, then these years will have greater influence on the likelihood for parameters that are pooled over time, such as the IRT discrimination parameters.

To address this possibility, we re-estimated our model on a subsample of our full dataset. Specifically, we divided the dataset into four equal time periods and calculated the average sample size across years in each period. For both domains, the 1954-72 period had the smallest sample sizes. Then, we randomly dropped survey respondents such that the average yearly sample size in each period matched that in the 1954-72 period. Thus, in the subsampled data the sample there is no general trend towards larger samples over time. We then estimated mass liberalism using the same measurement model as for the main analysis and estimated the same regression models on the results. The results of these analyses, reported in Tables A5-A8, are extremely similar to those for the full dataset. In particular, the point estimates for the pre/post-1972 difference in the responsiveness of non-Southern states are essentially identical to those for the full data, though the difference is not quite statistically significant for economics (Table A8). The most salient difference from the main analyses is that regional differences in responsiveness on economics disappear in the subsampled analyses: both regions appear to be responsive post-1972 but neither were pre-1972. 


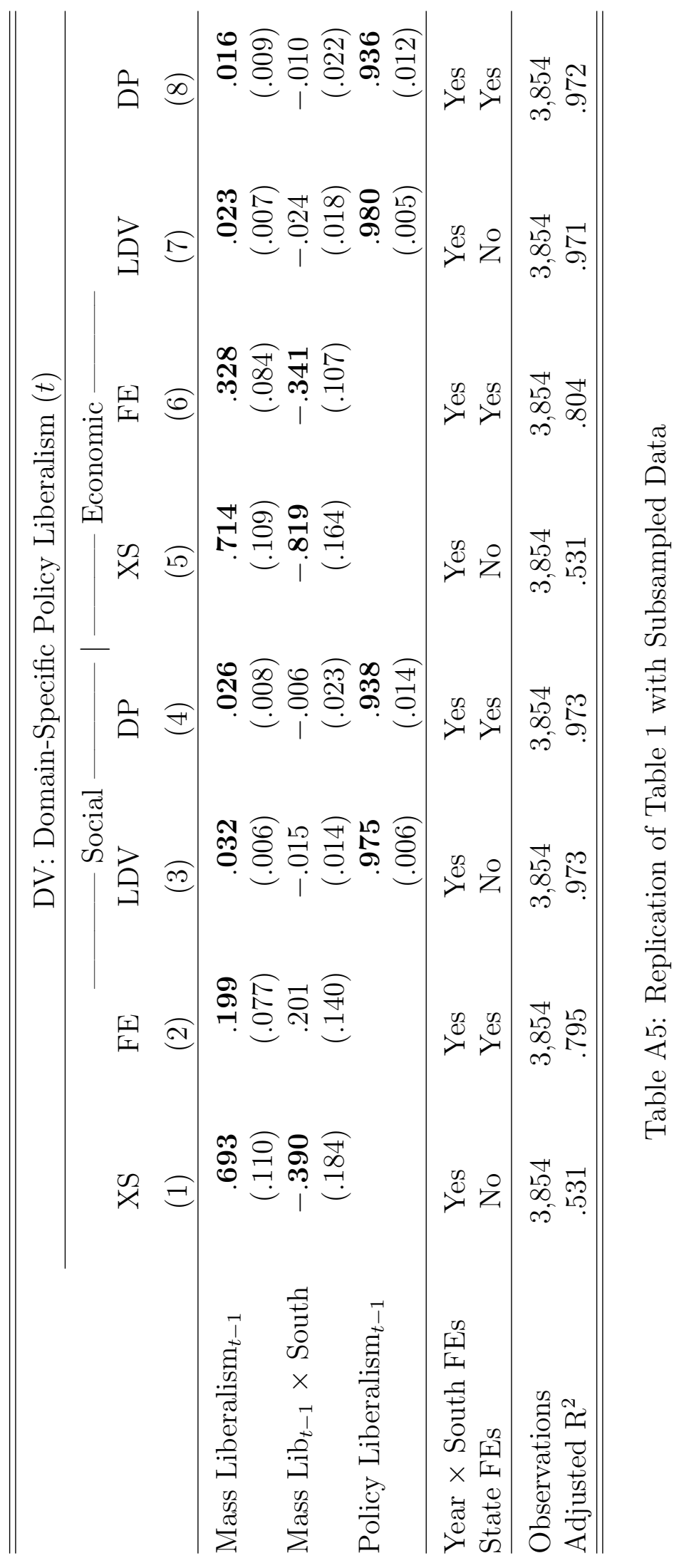




\begin{tabular}{|c|c|c|c|c|}
\hline & \multicolumn{4}{|c|}{ DV: Democratic Control Index $(t)$} \\
\hline & $(1)$ & $(2)$ & $(3)$ & $(4)$ \\
\hline Mass Social Lib Li-1 & $\begin{array}{r}.033 \\
(.018)\end{array}$ & & $\begin{array}{r}.028 \\
(.016)\end{array}$ & $\begin{array}{c}.021 \\
(.016)\end{array}$ \\
\hline Mass Econ Lib Li-1 $_{t-1}$ & & $\begin{array}{r}.030 \\
(.015)\end{array}$ & $\begin{array}{r}.025 \\
(.015)\end{array}$ & $\begin{array}{c}.026 \\
(.015)\end{array}$ \\
\hline Mass Dem PID PD-2 & & & & $\begin{array}{r}.075 \\
(.010)\end{array}$ \\
\hline Dem Control $_{t-1}$ & $\begin{array}{r}.661 \\
(.037) \\
\end{array}$ & $\begin{array}{r}.662 \\
(.036) \\
\end{array}$ & $\begin{array}{r}.658 \\
(.036) \\
\end{array}$ & $\begin{array}{r}.592 \\
(.033) \\
\end{array}$ \\
\hline Year FEs & Yes & Yes & Yes & Yes \\
\hline State FEs & Yes & Yes & Yes & Yes \\
\hline Observations & 1,755 & 1,755 & 1,755 & 1,497 \\
\hline Adjusted $\mathrm{R}^{2}$ & .719 & .719 & .720 & .723 \\
\hline
\end{tabular}

Table A6: Replication of Table 2 with Subsampled Data 


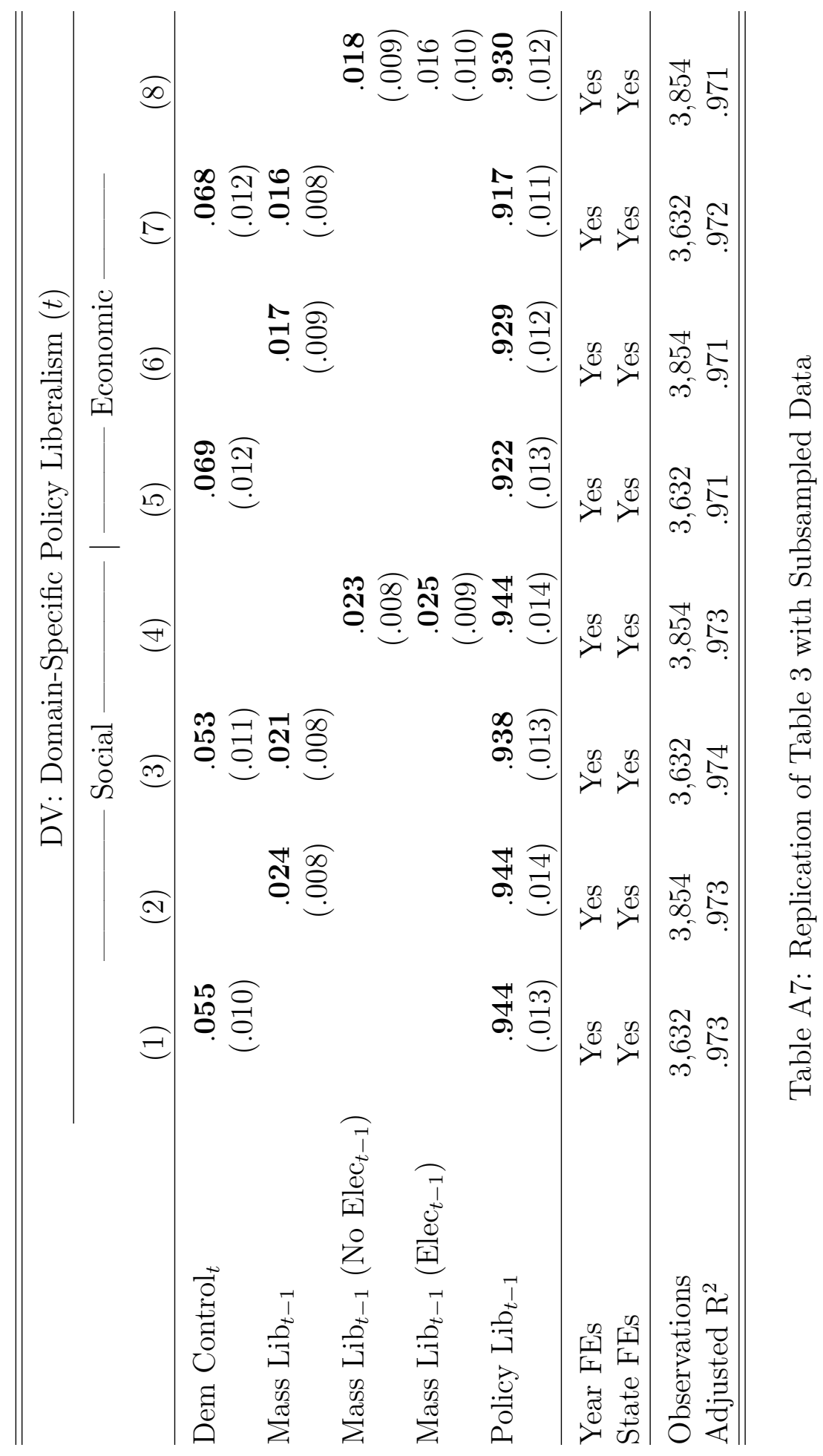




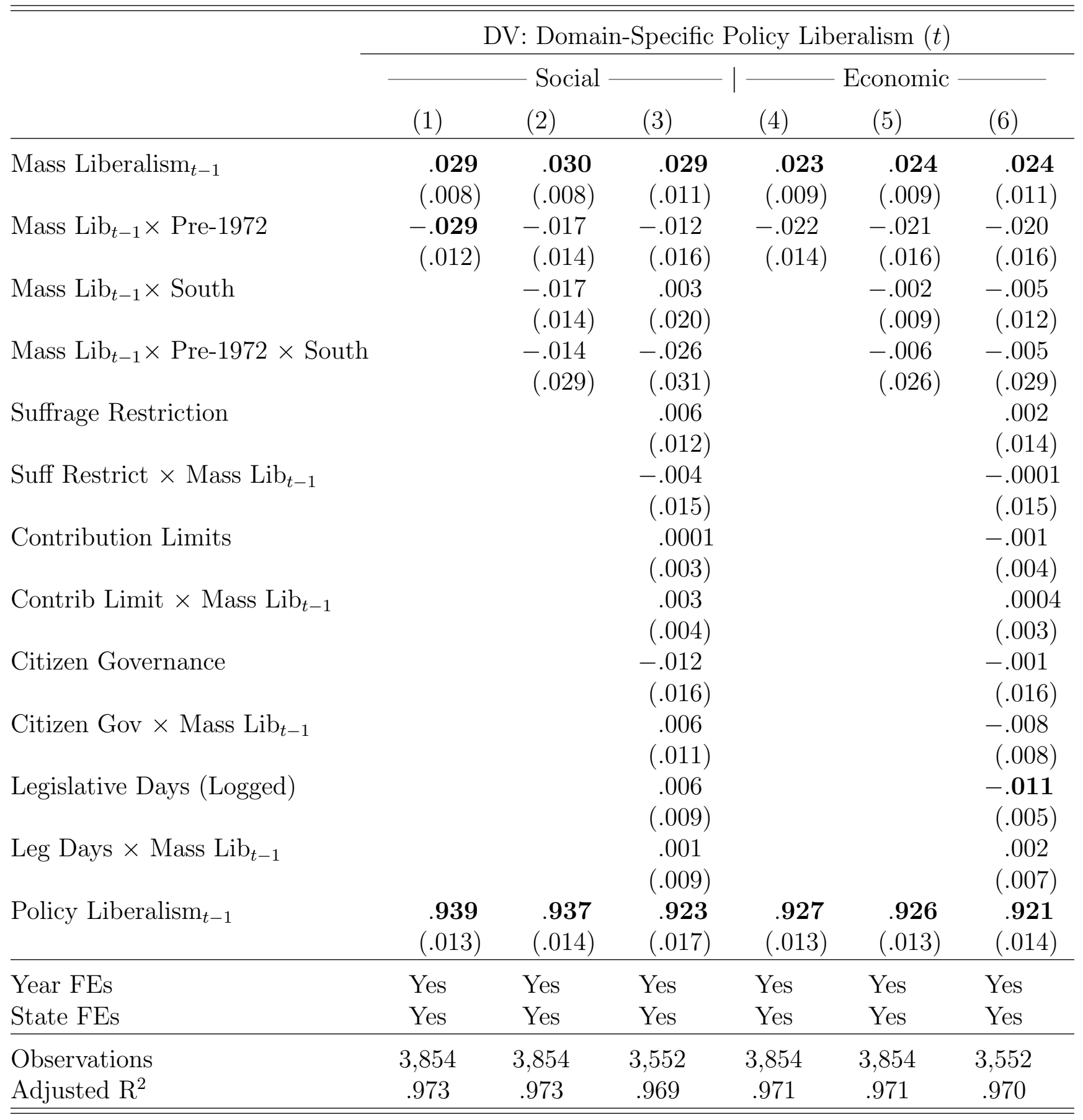

Table A8: Replication of Table 4 with Subsampled Data 


\section{F Alternative Dynamic Specifications}

\section{F.1 Autoregressive Distributed Lag Model}

The autoregressive distributed lag, or $\operatorname{ADL}(p, q ; n)$, model is a general dynamic model with $p$ lags of the dependent variable and $q$ lags of each of $n$ exogenous regressors. The primary specification we use in the main text of our paper is

$$
y_{s t}=\alpha_{s}+\gamma_{t}+\rho_{1} y_{s, t-1}+\beta_{1} x_{s, t-1}+\epsilon_{s t},
$$

which is a modified $\operatorname{ADL}(1,1 ; 1)$ model with state $\left(\alpha_{s}\right)$ and year $\left(\gamma_{t}\right)$ intercepts but without a term for contemporaneous mass liberalism $\left(x_{s t}\right)$. The last modification is what De Boef and Keele $(2008,187)$ call a "dead start" ADL model. The exclusion of $x_{s t}$ from the specification is designed to ensure that mass liberalism is measured before the value of policy liberalism in year $t$ is realized. We set $p$ to 1 because this is the average optimal lag length of the 50 statespecific time series of policy liberalism, as selected by the Akaike Information Criterion. We set $q$ to 0 because it relieves us of stipulating how long it takes for mass liberalism to affect policy liberalism. $\beta_{1}$ thus captures the effects of $x_{s, t-1}$ and (insofar as they are correleted with $x_{s, t-1}$ ) of higher-order lags of $x$, net of the portion of their effect that is mediated through $y_{s, t-1}$.

A still more general specification, however, would include higher-order lags of both the independent and dependent variables. We select $p=q=5$ because this is the first lag length at which neither policy liberalism nor mass liberalism independently predicts $y_{s t}$ in either issue domain (conditional on lags $1-4)$. This results in a modified $\operatorname{ADL}(5,5 ; 1)$ model, again with $x_{s t}$ omitted:

$$
y_{s t}=\alpha_{s}+\gamma_{t}+\sum_{p=1}^{5} \rho_{p} y_{s, t-p}+\sum_{q=1}^{5} \beta_{q} x_{s, t-q}+\epsilon_{s t} .
$$

The results of estimating this model are reported in Table A9. The salient results are: 


\begin{tabular}{|c|c|c|}
\hline & DV: Policy & ralism $(t)$ \\
\hline & Social & Economic \\
\hline & (1) & $(2)$ \\
\hline Mass Liberalism $(t-1)$ & 0.018 & 0.003 \\
\hline & $(0.013)$ & $(0.009)$ \\
\hline Mass Liberalism $(t-2)$ & 0.004 & 0.002 \\
\hline & $(0.015)$ & $(0.009)$ \\
\hline Mass Liberalism $(t-3)$ & 0.016 & -0.0002 \\
\hline & $(0.016)$ & $(0.010)$ \\
\hline Mass Liberalism $(t-4)$ & 0.002 & 0.011 \\
\hline & $(0.015)$ & $(0.009)$ \\
\hline Mass Liberalism $(t-5)$ & 0.003 & 0.005 \\
\hline & $(0.014)$ & $(0.009)$ \\
\hline Policy Liberalism $(t-1)$ & $0.878^{* * *}$ & $0.804^{* * *}$ \\
\hline & $(0.046)$ & $(0.029)$ \\
\hline Policy Liberalism $(t-2)$ & 0.050 & $0.073^{* *}$ \\
\hline & $(0.039)$ & $(0.031)$ \\
\hline Policy Liberalism $(t-3)$ & 0.012 & 0.020 \\
\hline & $(0.027)$ & $(0.020)$ \\
\hline Policy Liberalism $(t-4)$ & -0.0003 & $0.065^{* * *}$ \\
\hline & $(0.023)$ & $(0.022)$ \\
\hline Policy Liberalism $(t-5)$ & 0.002 & -0.015 \\
\hline & $(0.020)$ & $(0.017)$ \\
\hline Year FEs & Yes & Yes \\
\hline State FEs & Yes & Yes \\
\hline Sum Mass Lib, Lags 1-4 & $0.04^{* * *}$ & 0.016 \\
\hline & $(0.014)$ & $(0.012)$ \\
\hline Sum Mass Lib, Lags 1-5 & $0.043^{* * *}$ & $0.02^{* *}$ \\
\hline & $(0.01)$ & $(0.01)$ \\
\hline Sum Policy Lib, Lags 1-5 & $0.941^{* * *}$ & $0.947^{* * *}$ \\
\hline & $(0.01)$ & $(0.009)$ \\
\hline Observations & 3,654 & 3,654 \\
\hline $\mathrm{R}^{2}$ & 0.973 & 0.974 \\
\hline Adjusted $\mathrm{R}^{2}$ & 0.972 & 0.973 \\
\hline Note: & & $;{ }^{* * *} \mathrm{p}<0.01$ \\
\hline
\end{tabular}

Table A9: Results for Autoregressive Distributed Lag Model

- For both social and economic issues, no individual lag of mass liberalism is distinguishable from 0 when all five are included in the same model. 
- For both social and economic issues, the sum of the five mass liberalism lags is clearly positive, and very similar in magnitude to the estimated effect of mass liberalism $t-1$ when only it is included in the model (see Table 3, columns 2 and 6).

- For social but not economic issues, the sum of the first- through fourth-order lags of mass liberalism is the same magnitude as the sum of $1-5$. This is captures the effect of change in liberalism since $t-5$ (i.e., over a full four-year election cycle).

- The sum of the lags of policy liberalism closely matches the estimated coefficient for policy liberalism $t-1$ when only it is included in the model. Like the first-order lag alone, the sum of the lags is clearly less than 1 , indicating a (slight) tendency of policy liberalism to revert its state-specific long-term mean.

\section{F.2 First-Differenced Policy Liberalism}

As a further robustness check, we replicate our main results with first-differenced policy liberalism (i.e., $\Delta y_{s t}=y_{s t}-y_{s, t-1}$ ) as the dependent variable. The results are summarized in Table A10. Columns (1) and (5) report the results an error-correction model (ECM), which is simply an algebraic re-arrangement of an ADL model (De Boef and Keele 2008, 189-90). Under this re-arrangement, the coefficient on $y_{s, t-1}$ should be negative when a time series is stationary, which is clearly the case for both social and economic policy liberalism. As they should be, the point estimates are essentially identical to the dead start ADL specification we employ in the main text (the slight discrepancies from Table 3 stem from simulation error in the method of composition procedure).

Columns (2) and (6) remove lagged policy liberalism from the specification. This is equivalent to constraining the lag coefficient for $y_{s, t-1}$ to equal 1 . With state fixed effects in the model as well, this restriction implies that there is a long-term linear trend in policy liberalism within each state. It is worth noting that this restriction is clearly implausible in light of the estimates in the second row of columns (1) and (5). When we make this 
restriction, mass liberalism still predicts change in policy liberalism in the social domain, but not on economics. When we remove state fixed effects from the specification, as reported in columns (3) and (7), the economic result reappears.

Finally, columns (4) and (8) predict change in $y$ between $t-1$ and $t$ with change in $x$ one year previous (i.e., $t-2$ to $t-1$ ), controlling for $y_{t-1}$ and $x_{t-2}$. This specification is equivalent to what De Boef and Keele (2008) call the "general" ECM model, except that the independent variables are shifted back one year in time relative to the DVs. For social issues, there is clear evidence that recent changes in mass liberalism predict changes in policy liberalism, though $x_{t-2}$ continues to have predictive power as well. This is consistent with the results for the sum of lag coefficients for the ADL model reported in Table A9. For economic issues, change in $x$ between $t-2$ and $t-1$ is not statistically significant, though similar in magnitude to the estimated effect of $x_{s, t-1}$ in the corresponding dynamic panel specification (see column 6 of Table 3 ). The coefficient for $x_{t-2}$, however, is highly predictive. This suggests either that $x_{t-2}$ is proxying for other time-varying state-specific confounders or that the policy effects of mass economic liberalism take more than one year to be fully felt (a possibility also consistent with Table A9, in which the fourth-order lag of mass economic policy liberalism has the largest estimated coefficient). 


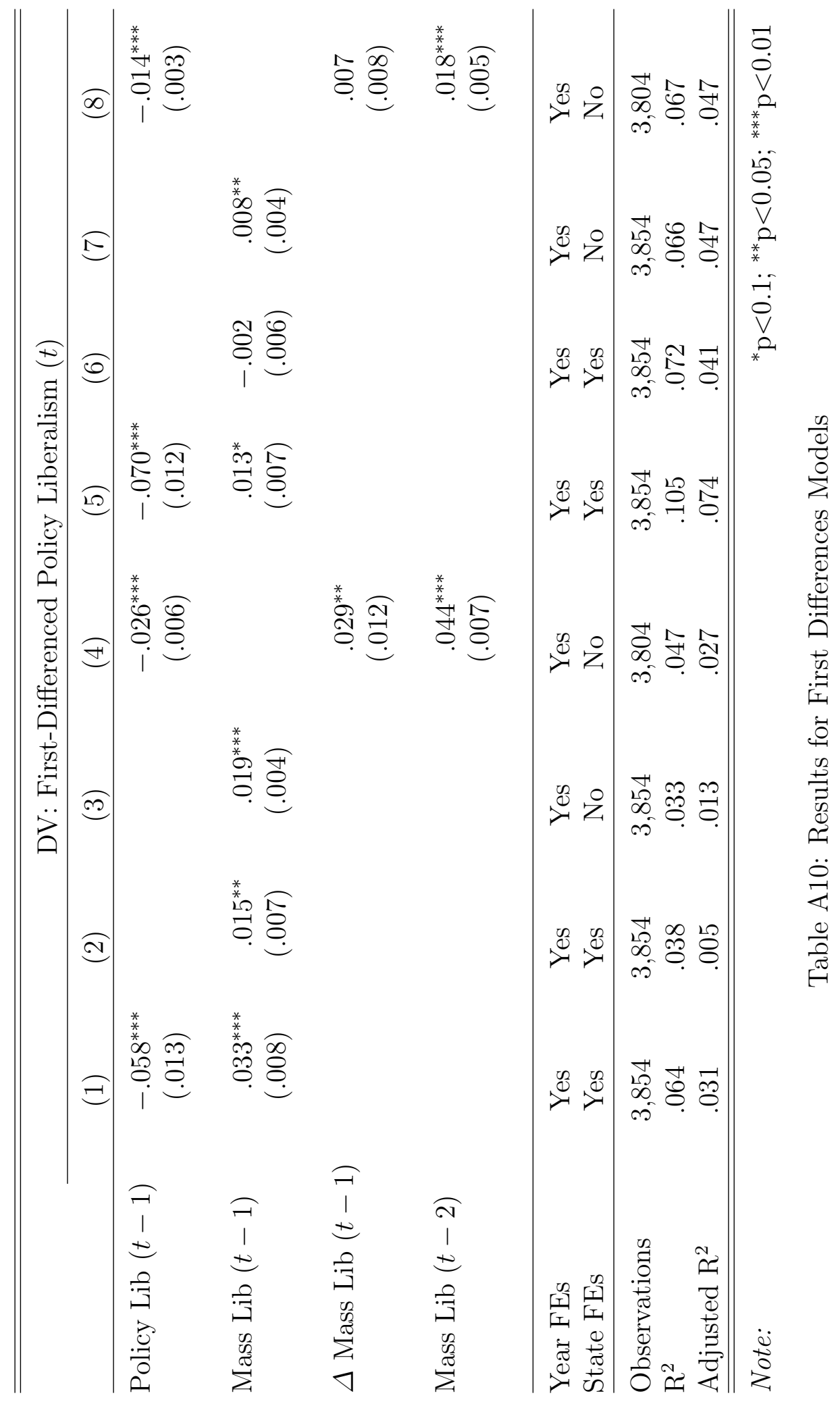




\section{G Effect of Individual Institutions on Responsiveness}

Table A11 reports the results of a re-analysis of columns (3) and (6) of Table 4, replacing the institution indices with their component variables. The institution variables in Table A11 are standardized to be mean-zero, unit-variance across state years. Across the 16 interactions between mass liberalism and individual institutions, the only significant coefficient is for a ban on campaign contributions from unions, which is estimated to increase responsiveness on economic policies by .012 (.006). The estimation of 1 significant effect out of 16 tests is not very surprising. Moreover, there is only modest evidence that institutional interactions matter collectively. Table A11 shows this by reporting the estimated sum of the institution interactions (multiplying the poll tax and literacy test estimates by -1 to reflect the expectation that they should have undermined responsiveness). The estimated sums are positive, but not statistically distinguishable from 0 .

The major difference between this table and Table 4 is that including all institutions individually largely wipes out the temporal differences in policy responsiveness reported in the main text. This suggests that at least part of the differences across eras may be attributable to institutional reforms. It should be noted, however, that the variables in this specification suffer from a relatively high degree of multicollinearity due to the correlations

among institutional variables and between them and geographic and time effects. This inflates the variance of the estimates and makes it difficult to draw firm conclusions about how responsiveness varies across different conditions. 


\begin{tabular}{|c|c|c|}
\hline & \multicolumn{2}{|c|}{ DV: Domain-Specific Policy Liberalism $(t)$} \\
\hline & Social & Economic \\
\hline & $(1)$ & $(2)$ \\
\hline \multirow[t]{2}{*}{ Mass Liberalism $_{t-1}$} & .035 & .020 \\
\hline & $(.014)$ & $(.009)$ \\
\hline \multirow{2}{*}{ Mass $\mathrm{Lib}_{t-1} \times$ Pre- 1972} & -.006 & -.013 \\
\hline & $(.025)$ & $(.014)$ \\
\hline \multirow{2}{*}{ Mass $\operatorname{Lib}_{t-1} \times$ South } & -.003 & -.031 \\
\hline & $(.022)$ & $(.014)$ \\
\hline \multirow{2}{*}{ Mass Lib ${ }_{t-1} \times$ Pre $-1972 \times$ South } & -.002 & .034 \\
\hline & $(.034)$ & $(.025)$ \\
\hline \multirow{2}{*}{ Union Contrib Ban } & -.011 & -.011 \\
\hline & $(.007)$ & $(.006)$ \\
\hline \multirow{2}{*}{ Individual Contrib Limit } & .003 & .006 \\
\hline & $(.007)$ & $(.007)$ \\
\hline \multirow[t]{2}{*}{ Corporate Contrib Limit } & .010 & .006 \\
\hline & $(.007)$ & $(.009)$ \\
\hline \multirow[t]{2}{*}{ Poll Tax } & .002 & .004 \\
\hline & $(.005)$ & $(.007)$ \\
\hline \multirow[t]{2}{*}{ Literacy Test } & .005 & -.002 \\
\hline & $(.007)$ & $(.007)$ \\
\hline \multirow[t]{2}{*}{ Direct Democracy } & .011 & .002 \\
\hline & $(.021)$ & $(.014)$ \\
\hline \multirow[t]{2}{*}{ Term Limits } & -.006 & -.002 \\
\hline & $(.005)$ & $(.005)$ \\
\hline \multirow[t]{2}{*}{ Legislative Days (Logged) } & .005 & -.007 \\
\hline & $(.006)$ & $(.004)$ \\
\hline \multirow[t]{2}{*}{ Union Contrib Ban $\times$ Mass $\operatorname{Lib}_{t-1}$} & .003 & .012 \\
\hline & $(.007)$ & $(.006)$ \\
\hline \multirow{2}{*}{ Individual Contrib Limit $\times$ Mass $\mathrm{Lib}_{t-1}$} & .009 & .002 \\
\hline & $(.007)$ & $(.005)$ \\
\hline \multirow[t]{2}{*}{ Corporate Contrib Limit $\times$ Mass Lib $_{t-1}$} & -.004 & -.005 \\
\hline & $(.007)$ & $(.005)$ \\
\hline \multirow[t]{2}{*}{ Poll Tax $\times$ Mass Lib $t-1$} & -.006 & -.003 \\
\hline & $(.006)$ & $(.005)$ \\
\hline \multirow[t]{2}{*}{ Literacy Test $\times$ Mass $\operatorname{Lib}_{t-1}$} & .003 & .001 \\
\hline & $(.007)$ & $(.005)$ \\
\hline \multirow[t]{2}{*}{ Direct Democracy $\times$ Mass Lib $_{t-1}$} & .005 & -.0001 \\
\hline & $(.007)$ & $(.005)$ \\
\hline \multirow[t]{2}{*}{ Term Limits $\times$ Mass Lib $\operatorname{Li}_{t-1}$} & .004 & .003 \\
\hline & $(.006)$ & $(.004)$ \\
\hline \multirow[t]{2}{*}{ Leg Days $\times$ Mass Lib $t-1$} & .002 & -.003 \\
\hline & $(.005)$ & $(.004)$ \\
\hline Year FEs \& State FEs \& LDV & Yes & Yes \\
\hline \multirow[t]{2}{*}{ Sum of Signed Institution Interactions } & .021 & .011 \\
\hline & $(.015)$ & $(.013)$ \\
\hline Observations & 3,552 & 3,552 \\
\hline $\mathrm{R}^{2}$ & .971 & .971 \\
\hline Adjusted $\mathrm{R}^{2}$ & .970 & .970 \\
\hline
\end{tabular}

Table A11: Institutional Moderators of Mass Liberalism 


\section{H Survey Questions for Mass Liberalism Models}

Table A12: Social Domain - Survey Question Text

\begin{tabular}{|c|c|c|c|}
\hline Year & Month & Item & Organization \\
\hline 1936 & December & Ban alcohol & Gallup \\
\hline 1936 & December & Death penalty & Gallup \\
\hline 1937 & December & Ban alcohol & Gallup \\
\hline 1937 & January & Women on juries & Gallup \\
\hline 1938 & October & Ban alcohol & Gallup \\
\hline 1938 & October & Birth control for married people & Gallup \\
\hline 1938 & April & Handgun registration & Gallup \\
\hline 1939 & December & Ban alcohol & Gallup \\
\hline 1939 & June & Ban alcohol & Gallup \\
\hline 1939 & December & Birth control for married people & Gallup \\
\hline 1940 & October & Ban alcohol & Gallup \\
\hline 1940 & August & Ban communist party & Gallup \\
\hline 1940 & January & Birth control for married people & Gallup \\
\hline 1941 & June & Allow liquor in army camps & Gallup \\
\hline 1941 & November & Ban alcohol & Gallup \\
\hline 1941 & May & Ban communist party & Gallup \\
\hline 1942 & February & Ban alcohol & Gallup \\
\hline 1942 & January & Ban alcohol & Gallup \\
\hline 1942 & November & Ban alcohol & Gallup \\
\hline 1942 & September & Ban alcohol & Gallup \\
\hline 1942 & June & Ban communist party & Gallup \\
\hline 1942 & January & Equal pay for women & Gallup \\
\hline 1943 & August & Ban alcohol & Gallup \\
\hline 1943 & December & Birth control for married people & Gallup \\
\hline 1943 & March & Sex education & Gallup \\
\hline 1944 & January & Ban alcohol & Gallup \\
\hline 1944 & November & Ban alcohol & Gallup \\
\hline 1944 & October & Ban alcohol & Gallup \\
\hline 1944 & September & Ban alcohol & Gallup \\
\hline 1945 & November & Ban alcohol & Gallup \\
\hline 1945 & October & Ban alcohol & Gallup \\
\hline 1945 & September & Equal pay for women & Gallup \\
\hline 1946 & December & Ban alcohol & Gallup \\
\hline 1946 & July & Ban alcohol & Gallup \\
\hline 1946 & October & Ban alcohol & Gallup \\
\hline 1946 & June & Ban communist party & Gallup \\
\hline 1946 & March & Ban communist party & Gallup \\
\hline 1946 & NA & Ban communists in civil service & Gallup \\
\hline 1947 & June & Assisted Suicide & Gallup \\
\hline 1947 & November & Ban alcohol & Gallup \\
\hline 1947 & October & Ban alcohol & Gallup \\
\hline 1947 & March & Ban communist party & Gallup \\
\hline 1947 & October & Ban communist party & Gallup \\
\hline 1947 & March & Ban communists in civil service & Gallup \\
\hline 1947 & March & Birth control for married people & Gallup \\
\hline 1948 & August & Ban alcohol & Gallup \\
\hline 1948 & October & Ban alcohol & Gallup \\
\hline 1948 & September & Ban alcohol & Gallup \\
\hline 1948 & May & Communists must register & Gallup \\
\hline 1949 & December & Ban alcohol & Gallup \\
\hline 1949 & March & Ban communist party & Gallup \\
\hline 1949 & November & Ban communist party & Gallup \\
\hline 1949 & February & Ban communists in civil service & Gallup \\
\hline 1949 & March & Communists must register & Gallup \\
\hline 1949 & November & Communists must register & Gallup \\
\hline 1949 & April & Test tube babies & Gallup \\
\hline 1950 & January & Assisted Suicide & Gallup \\
\hline 1950 & June & Ban alcohol & Gallup \\
\hline 1950 & July & Ban communist party & Gallup \\
\hline
\end{tabular}


Survey Text A12 Continued from previous page

\begin{tabular}{|c|c|c|c|}
\hline Year & Month & Item & Organization \\
\hline 1950 & July & Communists must register & Gallup \\
\hline 1951 & January & Ban communist party & Gallup \\
\hline 1951 & January & Sex education & Gallup \\
\hline 1952 & December & Ban alcohol & Gallup \\
\hline 1953 & October & Allow liquor at officers' clubs & Gallup \\
\hline 1953 & April & Communists must register & Gallup \\
\hline 1953 & November & Death penalty & Gallup \\
\hline 1953 & April & God in pledge to the flag & Gallup \\
\hline 1953 & April & Test tube babies & Gallup \\
\hline 1954 & December & Ban alcohol & Gallup \\
\hline 1954 & October & Corporal punishment in schools & Gallup \\
\hline 1955 & August & Ban alcohol & Gallup \\
\hline 1956 & August & Ban alcohol & Gallup \\
\hline 1956 & January & Ban alcohol & Gallup \\
\hline 1956 & April & Death penalty & Gallup \\
\hline 1956 & August & Limits on liquor consumption & Gallup \\
\hline 1957 & March & Allow women to drink in public places & Gallup \\
\hline 1957 & March & Ban alcohol & Gallup \\
\hline 1957 & September & Death penalty & Gallup \\
\hline 1958 & August & Ban alcohol & Gallup \\
\hline 1958 & December & Corporal punishment in schools & Gallup \\
\hline 1959 & December & Allow birth control for everyone & Gallup \\
\hline 1959 & December & Ban alcohol & Gallup \\
\hline 1959 & July & Permits for handguns & Gallup \\
\hline 1960 & April & Ban alcohol & Gallup \\
\hline 1960 & March & Death penalty & Gallup \\
\hline 1961 & March & Allow birth control for everyone & Gallup \\
\hline 1961 & May & Ban alcohol & Gallup \\
\hline 1961 & May & Ban alcohol & Gallup \\
\hline 1962 & August & Allow abortion for people with no money & Gallup \\
\hline 1962 & August & Allow abortion if deformed baby & Gallup \\
\hline 1962 & August & Allow abortion if healthy mother & Gallup \\
\hline 1962 & August & Allow birth control for everyone & Gallup \\
\hline 1963 & May & Allow birth control for everyone & Gallup \\
\hline 1963 & December & Permits for handguns & Gallup \\
\hline 1964 & October & Allow atheist teachers & NORC \\
\hline 1964 & November & Allow birth control for everyone & Gallup \\
\hline 1964 & October & Ban school prayer & NORC \\
\hline 1964 & October & Corporal punishment in schools & NORC \\
\hline 1964 & October & Death penalty & NORC \\
\hline 1964 & October & Death penalty & NORC \\
\hline 1964 & October & School prayer & ANES \\
\hline 1964 & September & School prayer amendment & Gallup \\
\hline 1964 & October & Teachers with beards & NORC \\
\hline 1964 & October & Teachers with beards & NORC \\
\hline 1965 & July & Allow 18 year olds to vote & Gallup \\
\hline 1965 & December & Allow abortion for people with no money & Gallup \\
\hline 1965 & December & Allow abortion if deformed baby & Gallup \\
\hline 1965 & December & Allow abortion if healthy mother & Gallup \\
\hline 1965 & November & Communists must register (v2) & Gallup \\
\hline 1965 & January & Death penalty & Gallup \\
\hline 1965 & January & Permits for handguns & Gallup \\
\hline 1965 & September & Permits for handguns & Gallup \\
\hline 1965 & April & Sex education & Gallup \\
\hline 1966 & January & Ban alcohol & Gallup \\
\hline 1966 & December & Birth control & Gallup \\
\hline 1966 & May & Death penalty & Gallup \\
\hline 1966 & December & Free birth control & Gallup \\
\hline 1966 & August & Permits for handguns & Gallup \\
\hline 1966 & October & School prayer & ANES \\
\hline 1967 & March & Allow 18 year olds to vote & Gallup \\
\hline 1967 & August & Allow birth control for everyone & Gallup \\
\hline 1967 & June & Death penalty & Gallup \\
\hline 1967 & August & Permits for handguns & Gallup \\
\hline 1968 & July & Allow 18 year olds to vote & Gallup \\
\hline
\end{tabular}


Survey Text A12 Continued from previous page

\begin{tabular}{|c|c|c|c|}
\hline Year & Month & Item & Organization \\
\hline 1968 & November & Police authority & $\begin{array}{l}\text { Comparative } \\
\text { State Elections } \\
\text { Project }\end{array}$ \\
\hline 1968 & October & School prayer & ANES \\
\hline 1969 & October & Allow 18 year olds to vote & Gallup \\
\hline 1969 & September & Allow abortion for people with no money & Gallup \\
\hline 1969 & September & Allow abortion if deformed baby & Gallup \\
\hline 1969 & September & Allow abortion if healthy mother & Gallup \\
\hline 1969 & November & Allow abortion in first trimester & Gallup \\
\hline 1969 & October & Birth control & Gallup \\
\hline 1969 & January & Death penalty & Gallup \\
\hline 1969 & October & Free birth control & Gallup \\
\hline 1969 & October & Legalize marijuana & Gallup \\
\hline 1970 & March & Allow 18 year olds to vote & Gallup \\
\hline 1970 & October & Allow 18 year olds to vote & Gallup \\
\hline 1970 & September & Allow 18 year olds to vote & Gallup \\
\hline 1970 & April & Corporal punishment in schools & Gallup \\
\hline 1970 & October & Legalize marijuana & Gallup \\
\hline 1970 & April & Sex education & Gallup \\
\hline 1971 & November & Death penalty & Gallup \\
\hline 1971 & October & Permits for handguns & Gallup \\
\hline 1972 & October & Abortion legal (v3) & ANES \\
\hline 1972 & December & Allow abortion in first trimester & Gallup \\
\hline 1972 & March & Death penalty & Gallup \\
\hline 1972 & November & Death penalty & Gallup \\
\hline 1972 & March & Legalize marijuana & Gallup \\
\hline 1972 & May & Permits for handguns & Gallup \\
\hline 1973 & May & Birth control & Gallup \\
\hline 1973 & various & Death penalty & GSS \\
\hline 1973 & various & Legal abortion after rape & GSS \\
\hline 1973 & January & Legalize marijuana & Gallup \\
\hline 1973 & various & Permit required to own gun & GSS \\
\hline 1974 & March & Allow abortion in first trimester & Gallup \\
\hline 1974 & October & Allow abortion in first trimester & Gallup \\
\hline 1974 & May & Constitutional amendment to allow aid for parochial schools & Gallup \\
\hline 1974 & April & Death penalty & Roper \\
\hline 1974 & October & Death penalty & Gallup \\
\hline 1974 & various & Death penalty & GSS \\
\hline 1974 & October & Equal rights amendment & Gallup \\
\hline 1974 & various & Legal abortion after rape & GSS \\
\hline 1974 & October & Legalize marijuana & Gallup \\
\hline 1974 & various & Permit required to own gun & GSS \\
\hline 1974 & October & Permits for handguns & Gallup \\
\hline 1974 & May & School prayer amendment & Gallup \\
\hline 1975 & April & Abortion legal & Gallup \\
\hline 1975 & various & Death penalty & GSS \\
\hline 1975 & December & Equal rights amendment & Roper \\
\hline 1975 & July & Equal rights amendment & Roper \\
\hline 1975 & March & Equal rights amendment & Gallup \\
\hline 1975 & various & Legal abortion after rape & GSS \\
\hline 1975 & December & Legalize marijuana & Roper \\
\hline 1975 & various & Permit required to own gun & GSS \\
\hline 1976 & October & Abortion legal (v3) & ANES \\
\hline 1976 & October & Constitutional amendment to ban abortion (v2) & ANES \\
\hline 1976 & April & Death penalty & Gallup \\
\hline 1976 & various & Death penalty & GSS \\
\hline 1976 & March & Equal rights amendment & Gallup \\
\hline 1976 & various & Legal abortion after rape & GSS \\
\hline 1976 & various & Permit required to own gun & GSS \\
\hline 1977 & December & Abortion legal & Gallup \\
\hline 1977 & various & Death penalty & GSS \\
\hline 1977 & December & Equal rights amendment & Roper \\
\hline 1977 & March & Equal rights amendment & Time \\
\hline 1977 & November & Equal rights amendment & Time \\
\hline 1977 & various & Legal abortion after rape & GSS \\
\hline
\end{tabular}


Survey Text A12 Continued from previous page

\begin{tabular}{|c|c|c|c|}
\hline Year & Month & Item & Organization \\
\hline 1977 & various & Legal abortion for any reason & GSS \\
\hline 1977 & April & Legalize marijuana & Gallup \\
\hline 1977 & December & Legalize marijuana & Roper \\
\hline 1977 & various & Permit required to own gun & GSS \\
\hline 1977 & December & Sex education & Gallup \\
\hline 1978 & October & Abortion legal (v3) & ANES \\
\hline 1978 & March & Death penalty & Gallup \\
\hline 1978 & various & Death penalty & GSS \\
\hline 1978 & July & Equal rights amendment & Roper \\
\hline 1978 & various & Legal abortion after rape & GSS \\
\hline 1978 & various & Legal abortion for any reason & GSS \\
\hline 1978 & January & Sex education & CBS \\
\hline 1979 & February & Abortion legal & Gallup \\
\hline 1979 & May & Ban alcohol & Gallup \\
\hline 1979 & March & Equal rights amendment & Roper \\
\hline 1979 & July & Legalize marijuana & CBS \\
\hline 1979 & May & Legalize marijuana & Gallup \\
\hline 1980 & October & Abortion legal (v3) & ANES \\
\hline 1980 & September & Allow gays to teach in school & Gallup \\
\hline 1980 & November & Constitutional amendment to allow aid for parochial schools & Gallup \\
\hline 1980 & June & Constitutional amendment to ban abortion & CBS \\
\hline 1980 & various & Death penalty & GSS \\
\hline 1980 & August & Equal rights amendment & Time \\
\hline 1980 & February & Equal rights amendment & CBS \\
\hline 1980 & July & Equal rights amendment & Gallup \\
\hline 1980 & July & Equal rights amendment & Gallup \\
\hline 1980 & June & Equal rights amendment & CBS \\
\hline 1980 & March & Equal rights amendment & Time \\
\hline 1980 & March & Equal rights amendment & CBS \\
\hline 1980 & November & Equal rights amendment & LATimes \\
\hline 1980 & October & Equal rights amendment & CBS \\
\hline 1980 & October & Equal rights amendment & CBS \\
\hline 1980 & September & Equal rights amendment & Gallup \\
\hline 1980 & September & Equal rights amendment & CBS \\
\hline 1980 & September & Equal rights amendment & CBS \\
\hline 1980 & various & Legal abortion after rape & GSS \\
\hline 1980 & various & Legal abortion for any reason & GSS \\
\hline 1980 & June & Legalize marijuana & Gallup \\
\hline 1980 & various & Permit required to own gun & GSS \\
\hline 1980 & October & School prayer & ANES \\
\hline 1980 & March & School prayer amendment & Gallup \\
\hline 1981 & May & Abortion legal & Gallup \\
\hline 1981 & January & Ban alcohol & Gallup \\
\hline 1981 & April & Ban handguns & CBS \\
\hline 1981 & February & Death penalty & Gallup \\
\hline 1981 & April & Equal rights amendment & LATimes \\
\hline 1981 & April & Equal rights amendment & CBS \\
\hline 1981 & December & Equal rights amendment & Gallup \\
\hline 1981 & July & Equal rights amendment & Gallup \\
\hline 1981 & May & Equal rights amendment & Time \\
\hline 1981 & September & Equal rights amendment & Time \\
\hline 1981 & May & Sex education & Gallup \\
\hline 1982 & October & Abortion legal (v3) & ANES \\
\hline 1982 & September & Ban handguns & Gallup \\
\hline 1982 & September & Constitutional amendment to ban abortion & CBS \\
\hline 1982 & September & Death penalty & Gallup \\
\hline 1982 & various & Death penalty & GSS \\
\hline 1982 & June & Equal rights amendment & Gallup \\
\hline 1982 & October & Equal rights amendment & ANES \\
\hline 1982 & September & Equal rights amendment & Gallup \\
\hline 1982 & various & Legal abortion after rape & GSS \\
\hline 1982 & various & Legal abortion for any reason & GSS \\
\hline 1982 & various & Permit required to own gun & GSS \\
\hline 1982 & September & School prayer amendment & Gallup \\
\hline 1983 & December & Death penalty & Time \\
\hline
\end{tabular}


Survey Text A12 Continued from previous page

\begin{tabular}{|c|c|c|c|}
\hline Year & Month & Item & Organization \\
\hline 1983 & September & Death penalty & Time \\
\hline 1983 & various & Death penalty & GSS \\
\hline 1983 & December & Equal rights amendment & Time \\
\hline 1983 & September & Equal rights amendment & Time \\
\hline 1983 & various & Legal abortion after rape & GSS \\
\hline 1983 & various & Legal abortion for any reason & GSS \\
\hline 1983 & July & School prayer amendment & Gallup \\
\hline 1984 & October & Abortion legal (v3) & ANES \\
\hline 1984 & July & Ban alcohol & Gallup \\
\hline 1984 & October & Constitutional amendment to ban abortion & CBS \\
\hline 1984 & September & Constitutional amendment to ban abortion & CBS \\
\hline 1984 & October & Constitutional amendment to ban abortion (v2) & ANES \\
\hline 1984 & September & Death penalty & Time \\
\hline 1984 & various & Death penalty & GSS \\
\hline 1984 & October & Equal rights amendment & Gallup \\
\hline 1984 & September & Equal rights amendment & Time \\
\hline 1984 & October & Government should help women & ANES \\
\hline 1984 & various & Legal abortion after rape & GSS \\
\hline 1984 & various & Legal abortion for any reason & GSS \\
\hline 1984 & various & Permit required to own gun & GSS \\
\hline 1984 & October & School prayer & ANES \\
\hline 1984 & May & School prayer amendment & Gallup \\
\hline 1984 & September & School prayer amendment & CBS \\
\hline 1985 & January & Abortion legal & Gallup \\
\hline 1985 & August & Constitutional amendment to allow aid for parochial schools & Gallup \\
\hline 1985 & February & Death penalty & LATimes \\
\hline 1985 & January & Death penalty & Gallup \\
\hline 1985 & various & Death penalty & GSS \\
\hline 1985 & various & Legal abortion after rape & GSS \\
\hline 1985 & various & Legal abortion for any reason & GSS \\
\hline 1985 & June & Legalize marijuana & Gallup \\
\hline 1985 & May & Legalize marijuana & $\mathrm{ABC}$ \\
\hline 1985 & various & Permit required to own gun & GSS \\
\hline 1986 & October & Abortion legal (v3) & ANES \\
\hline 1986 & January & Death penalty & Gallup \\
\hline 1986 & July & Death penalty & LATimes \\
\hline 1986 & various & Death penalty & GSS \\
\hline 1986 & April & Legalize marijuana & $\mathrm{ABC}$ \\
\hline 1986 & August & Legalize marijuana & $\mathrm{ABC}$ \\
\hline 1986 & March & Legalize marijuana & $\mathrm{ABC}$ \\
\hline 1986 & May & Legalize marijuana & $\mathrm{ABC}$ \\
\hline 1986 & October & School prayer (v2) & ANES \\
\hline 1987 & July & Ban alcohol & Gallup \\
\hline 1987 & May & Constitutional amendment to ban abortion & CBS \\
\hline 1987 & various & Death penalty & GSS \\
\hline 1987 & April & Equal rights amendment & $\mathrm{ABC}$ \\
\hline 1987 & August & Equal rights amendment & LATimes \\
\hline 1987 & May & Equal rights amendment & CBS \\
\hline 1987 & various & Legal abortion after rape & GSS \\
\hline 1987 & various & Legal abortion for any reason & GSS \\
\hline 1987 & November & Legalize marijuana & Gallup \\
\hline 1987 & various & Permit required to own gun & GSS \\
\hline 1987 & April & School prayer amendment & $\mathrm{ABC}$ \\
\hline 1987 & April & School prayer amendment & Gallup \\
\hline 1987 & May & School prayer amendment & Gallup \\
\hline 1987 & May & School prayer amendment & CBS \\
\hline 1987 & September & School prayer amendment & CBS \\
\hline 1988 & September & Abortion legal & Gallup \\
\hline 1988 & October & Abortion legal (v3) & ANES \\
\hline 1988 & October & Abortion legal (v4) & ANES \\
\hline 1988 & October & Ban handguns & CBS \\
\hline 1988 & October & Death penalty & CBS \\
\hline 1988 & September & Death penalty & Gallup \\
\hline 1988 & various & Death penalty & GSS \\
\hline 1988 & various & Gay marriage & GSS \\
\hline
\end{tabular}


Survey Text A12 Continued from previous page

\begin{tabular}{|c|c|c|c|}
\hline Year & Month & Item & Organization \\
\hline 1988 & October & Laws to protect gays & ANES \\
\hline 1988 & various & Legal abortion after rape & GSS \\
\hline 1988 & various & Legal abortion for any reason & GSS \\
\hline 1988 & September & Legalize marijuana & $\mathrm{ABC}$ \\
\hline 1988 & various & Permit required to own gun & GSS \\
\hline 1988 & October & School prayer (v2) & ANES \\
\hline 1988 & August & School prayer amendment & CBS \\
\hline 1989 & April & Abortion legal & Gallup \\
\hline 1989 & July & Abortion legal & Gallup \\
\hline 1989 & March & Abortion notification & LATimes \\
\hline 1989 & March & Assault weapon ban & CBS \\
\hline 1989 & June & Ban flag burning & Gallup \\
\hline 1989 & March & Ban handguns & CBS \\
\hline 1989 & January & Death penalty & CBS \\
\hline 1989 & March & Death penalty & LATimes \\
\hline 1989 & October & Death penalty & Gallup \\
\hline 1989 & various & Death penalty & GSS \\
\hline 1989 & various & Legal abortion after rape & GSS \\
\hline 1989 & various & Legal abortion for any reason & GSS \\
\hline 1989 & various & Permit required to own gun & GSS \\
\hline 1990 & October & Abortion legal (v3) & ANES \\
\hline 1990 & October & Abortion legal (v4) & ANES \\
\hline 1990 & July & Abortion notification & $\mathrm{ABC}$ \\
\hline 1990 & May & Abortion notification & Time \\
\hline 1990 & October & Ban flag burning & ANES \\
\hline 1990 & October & Death penalty & ANES \\
\hline 1990 & various & Death penalty & GSS \\
\hline 1990 & various & Legal abortion after rape & GSS \\
\hline 1990 & various & Legal abortion for any reason & GSS \\
\hline 1990 & various & Permit required to own gun & GSS \\
\hline 1990 & October & School prayer (v2) & ANES \\
\hline 1991 & June & Abortion legal & Gallup \\
\hline 1991 & various & Death penalty & GSS \\
\hline 1991 & various & Legal abortion after rape & GSS \\
\hline 1991 & various & Legal abortion for any reason & GSS \\
\hline 1991 & various & Permit required to own gun & GSS \\
\hline 1992 & January & Abortion legal & Gallup \\
\hline 1992 & July & Abortion legal & Gallup \\
\hline 1992 & June & Abortion legal & Gallup \\
\hline 1992 & October & Abortion legal (v3) & ANES \\
\hline 1992 & October & Abortion legal (v4) & ANES \\
\hline 1992 & September & Allow gays to adopt children & Time \\
\hline 1992 & January & Assault weapon ban & $\mathrm{CBS}$ \\
\hline 1992 & January & Ban handguns & CBS \\
\hline 1992 & October & Death penalty & ANES \\
\hline 1992 & October & Laws to protect gays & ANES \\
\hline 1992 & October & School prayer (v2) & ANES \\
\hline 1993 & March & Abortion legal & Gallup \\
\hline 1993 & December & Assault weapon ban & Gallup \\
\hline 1993 & December & Assault weapon ban & LATimes \\
\hline 1993 & March & Assault weapon ban & Gallup \\
\hline 1993 & November & Assault weapon ban & $\mathrm{ABC}$ \\
\hline 1993 & December & Ban handguns & CBS \\
\hline 1993 & various & Death penalty & GSS \\
\hline 1993 & various & Legal abortion after rape & GSS \\
\hline 1993 & various & Legal abortion for any reason & GSS \\
\hline 1993 & various & Permit required to own gun & GSS \\
\hline 1994 & March & Abortion legal & Gallup \\
\hline 1994 & September & Abortion legal & Gallup \\
\hline 1994 & October & Abortion legal (v3) & ANES \\
\hline 1994 & June & Allow gays to adopt children & Time \\
\hline 1994 & June & Allow gays to teach in school & Time \\
\hline 1994 & June & Allow gays to teach in school & Time \\
\hline 1994 & October & Assault weapon ban & ANES \\
\hline 1994 & June & Ban alcohol & Gallup \\
\hline
\end{tabular}


Survey Text A12 Continued from previous page

\begin{tabular}{|c|c|c|c|}
\hline Year & Month & Item & Organization \\
\hline 1994 & January & Ban handguns & CBS \\
\hline 1994 & September & Death penalty & Gallup \\
\hline 1994 & various & Death penalty & GSS \\
\hline 1994 & various & Legal abortion after rape & GSS \\
\hline 1994 & various & Legal abortion for any reason & GSS \\
\hline 1994 & various & Permit required to own gun & GSS \\
\hline 1994 & October & School prayer (v2) & ANES \\
\hline 1994 & July & School prayer amendment & CBS \\
\hline 1994 & November & School prayer amendment & CBS \\
\hline 1994 & November & School prayer amendment & Gallup \\
\hline 1995 & February & Abortion legal & Gallup \\
\hline 1995 & September & Abortion legal & Gallup \\
\hline 1995 & April & Assault weapon ban & CBS \\
\hline 1995 & April & Assault weapon ban & Gallup \\
\hline 1995 & February & Assault weapon ban & CBS \\
\hline 1995 & April & Ban handguns & CBS \\
\hline 1995 & January & Death penalty & $\mathrm{ABC}$ \\
\hline 1995 & May & Death penalty & Gallup \\
\hline 1995 & September & Legalize marijuana & Gallup \\
\hline 1995 & January & School prayer amendment & $\mathrm{ABC}$ \\
\hline 1996 & July & Abortion legal & Gallup \\
\hline 1996 & November & Abortion legal & Gallup \\
\hline 1996 & October & Abortion legal (v3) & ANES \\
\hline 1996 & June & Allow gay marriage & Pew \\
\hline 1996 & April & Assault weapon ban & Gallup \\
\hline 1996 & August & Assault weapon ban & $\mathrm{ABC}$ \\
\hline 1996 & January & Assault weapon ban & CBS \\
\hline 1996 & June & Ban alcohol & Gallup \\
\hline 1996 & February & Ban handguns & CBS \\
\hline 1996 & October & Ban on partial birth abortion & ANES \\
\hline 1996 & October & Constitutional amendment to ban abortion (v2) & ANES \\
\hline 1996 & August & Death penalty & $\mathrm{ABC}$ \\
\hline 1996 & June & Death penalty & Pew \\
\hline 1996 & various & Death penalty & GSS \\
\hline 1996 & October & Laws to protect gays & ANES \\
\hline 1996 & various & Legal abortion after rape & GSS \\
\hline 1996 & various & Legal abortion for any reason & GSS \\
\hline 1996 & various & Permit required to own gun & GSS \\
\hline 1996 & October & School prayer (v2) & ANES \\
\hline 1996 & August & School prayer amendment & $\mathrm{ABC}$ \\
\hline 1996 & November & School prayer amendment & $\mathrm{ABC}$ \\
\hline 1997 & August & Abortion legal & Gallup \\
\hline 1997 & November & Abortion legal & Gallup \\
\hline 1997 & March & Ban on partial birth abortion & Gallup \\
\hline 1997 & November & Ban on partial birth abortion & Gallup \\
\hline 1997 & June & Death penalty & Time \\
\hline 1997 & June & Death penalty & CBS \\
\hline 1998 & January & Abortion legal & Gallup \\
\hline 1998 & October & Abortion legal (v3) & ANES \\
\hline 1998 & October & Allow gays to adopt children & Time \\
\hline 1998 & October & Ban on partial birth abortion & ANES \\
\hline 1998 & various & Death penalty & GSS \\
\hline 1998 & various & Legal abortion after rape & GSS \\
\hline 1998 & various & Legal abortion for any reason & GSS \\
\hline 1998 & various & Permit required to own gun & GSS \\
\hline 1998 & October & School prayer (v2) & ANES \\
\hline 1998 & September & Trigger locks on guns & Pew \\
\hline 1999 & May & Abortion legal & Gallup \\
\hline 1999 & various & Abortion legal (v5) & NAES \\
\hline 1999 & April & Assault weapon ban & CBS \\
\hline 1999 & September & Assault weapon ban & $\mathrm{ABC}$ \\
\hline 1999 & April & Ban handguns & $\mathrm{CBS}$ \\
\hline 1999 & August & Ban handguns & CBS \\
\hline 1999 & September & Ban handguns & $\mathrm{ABC}$ \\
\hline 1999 & May & Ban on partial birth abortion & Gallup \\
\hline
\end{tabular}


Survey Text A12 Continued from previous page

\begin{tabular}{|c|c|c|c|}
\hline Year & Month & Item & Organization \\
\hline 1999 & February & Death penalty & Gallup \\
\hline 1999 & various & Gun control & NAES \\
\hline 1999 & various & Law protecting gay from discrimination (v2) & NAES \\
\hline 1999 & various & School vouchers & NAES \\
\hline 1999 & August & Trigger locks on guns & CBS \\
\hline 1999 & July & Trigger locks on guns & CBS \\
\hline 1999 & May & Trigger locks on guns & $\mathrm{ABC}$ \\
\hline 1999 & September & Trigger locks on guns & $\mathrm{ABC}$ \\
\hline 2000 & April & Abortion legal & Gallup \\
\hline 2000 & January & Abortion legal & Gallup \\
\hline 2000 & October & Abortion legal (v3) & ANES \\
\hline 2000 & various & Abortion legal (v5) & NAES \\
\hline 2000 & March & Assault weapon ban & CBS \\
\hline 2000 & May & Assault weapon ban & $\mathrm{ABC}$ \\
\hline 2000 & May & Assault weapon ban & CBS \\
\hline 2000 & October & Assault weapon ban & Gallup \\
\hline 2000 & March & Ban handguns & CBS \\
\hline 2000 & May & Ban handguns & $\mathrm{ABC}$ \\
\hline 2000 & April & Ban on partial birth abortion & Gallup \\
\hline 2000 & October & Ban on partial birth abortion & Gallup \\
\hline 2000 & February & Death penalty & Gallup \\
\hline 2000 & June & Death penalty & Gallup \\
\hline 2000 & various & Death penalty & GSS \\
\hline 2000 & various & Gays in military & NAES \\
\hline 2000 & various & Gun control & NAES \\
\hline 2000 & various & Law protecting gay from discrimination (v2) & NAES \\
\hline 2000 & various & Laws to protect gays & NAES \\
\hline 2000 & various & Legal abortion after rape & GSS \\
\hline 2000 & various & Legal abortion for any reason & GSS \\
\hline 2000 & various & Permit required to own gun & GSS \\
\hline 2000 & May & School prayer amendment & WashPost \\
\hline 2000 & September & School prayer amendment & Gallup \\
\hline 2000 & various & School prayer amendment & NAES \\
\hline 2000 & various & School vouchers & NAES \\
\hline 2000 & July & Trigger locks on guns & CBS \\
\hline 2000 & May & Trigger locks on guns & CBS \\
\hline 2000 & May & Trigger locks on guns & $\mathrm{ABC}$ \\
\hline 2001 & August & Abortion legal & Gallup \\
\hline 2001 & March & Abortion legal & Gallup \\
\hline 2001 & April & Death penalty & CBS \\
\hline 2001 & August & Death penalty & CBS \\
\hline 2001 & February & Death penalty & Gallup \\
\hline 2001 & June & Death penalty & CBS \\
\hline 2001 & August & Legalize marijuana & Gallup \\
\hline 2001 & January & School vouchers & CBS \\
\hline 2001 & March & School vouchers & CBS \\
\hline 2002 & February & Abortion legal & Gallup \\
\hline 2002 & March & Abortion legal & Gallup \\
\hline 2002 & March & Death penalty & Pew \\
\hline 2002 & various & Death penalty & GSS \\
\hline 2002 & various & Legal abortion after rape & GSS \\
\hline 2002 & various & Legal abortion for any reason & GSS \\
\hline 2002 & various & Permit required to own gun & GSS \\
\hline 2003 & January & Abortion legal & Gallup \\
\hline 2003 & October & Abortion legal & Gallup \\
\hline 2003 & various & Abortion legal (v5) & NAES \\
\hline 2003 & Jan & Abortion notification & Gallup \\
\hline 2003 & various & Allow gay marriage & NAES \\
\hline 2003 & various & Assault weapon ban & NAES \\
\hline 2003 & various & Ban on partial birth abortion & NAES \\
\hline 2003 & various & Civil unions & NAES \\
\hline 2003 & various & Constitutional amendment to ban abortion (v2) & NAES \\
\hline 2003 & January & Death penalty & $\mathrm{ABC}$ \\
\hline 2003 & June & Death penalty & Pew \\
\hline 2003 & various & Gay marriage amendment & NAES \\
\hline
\end{tabular}


Survey Text A12 Continued from previous page

\begin{tabular}{|c|c|c|c|}
\hline Year & Month & Item & Organization \\
\hline 2003 & various & Gun control & NAES \\
\hline 2003 & various & School vouchers & NAES \\
\hline 2004 & October & Abortion legal (v3) & ANES \\
\hline 2004 & various & Abortion legal (v5) & NAES \\
\hline 2004 & August & Allow gay marriage & Pew \\
\hline 2004 & February & Allow gay marriage & Pew \\
\hline 2004 & July & Allow gay marriage & Pew \\
\hline 2004 & March & Allow gay marriage & Pew \\
\hline 2004 & various & Assault weapon ban & NAES \\
\hline 2004 & various & Ban on partial birth abortion & NAES \\
\hline 2004 & August & Civil unions & Pew \\
\hline 2004 & July & Civil unions & Pew \\
\hline 2004 & March & Civil unions & Pew \\
\hline 2004 & various & Death penalty & GSS \\
\hline 2004 & various & Gay marriage & GSS \\
\hline 2004 & August & Gay marriage amendment & Pew \\
\hline 2004 & February & Gay marriage amendment & Gallup \\
\hline 2004 & July & Gay marriage amendment & Gallup \\
\hline 2004 & March & Gay marriage amendment & Gallup \\
\hline 2004 & March & Gay marriage amendment & Pew \\
\hline 2004 & various & Gun control & NAES \\
\hline 2004 & October & Laws to protect gays & ANES \\
\hline 2004 & various & Legal abortion after rape & GSS \\
\hline 2004 & various & Legal abortion for any reason & GSS \\
\hline 2004 & various & Permit required to own gun & GSS \\
\hline 2004 & various & School vouchers & NAES \\
\hline 2005 & June & Abortion legal & Gallup \\
\hline 2005 & March & Abortion legal & Gallup \\
\hline 2005 & November & Abortion legal & Gallup \\
\hline 2005 & July & Abortion notification & CBS \\
\hline 2005 & July & Abortion notification & Pew \\
\hline 2005 & November & Abortion notification & Gallup \\
\hline 2005 & July & Ban flag burning & Pew \\
\hline 2005 & June & Ban flag burning & Gallup \\
\hline 2005 & November & Constitutional amendment to ban abortion (v2) & Gallup \\
\hline 2005 & August & Death penalty & Pew \\
\hline 2005 & July & Death penalty & Pew \\
\hline 2005 & June & Death penalty & $\mathrm{ABC}$ \\
\hline 2005 & April & Gay marriage amendment & $\mathrm{ABC}$ \\
\hline 2005 & April & Gay marriage amendment & Gallup \\
\hline 2005 & July & Gay marriage amendment & Pew \\
\hline 2005 & March & Gay marriage amendment & Gallup \\
\hline 2005 & August & Immigration reform & $\mathrm{ABC}$ \\
\hline 2005 & December & Immigration reform & $\mathrm{ABC}$ \\
\hline 2005 & January & Immigration reform & $\mathrm{ABC}$ \\
\hline 2005 & January & Immigration reform & $\mathrm{ABC}$ \\
\hline 2005 & August & Stem cell research & Gallup \\
\hline 2005 & July & Stem cell research & CBS \\
\hline 2005 & June & Stem cell research & $\mathrm{ABC}$ \\
\hline 2005 & May & Stem cell research & Gallup \\
\hline 2005 & May & Stem cell research & CBS \\
\hline 2006 & June & Abortion legal & Gallup \\
\hline 2006 & June & Allow gay marriage & Pew \\
\hline 2006 & March & Allow gay marriage & Pew \\
\hline 2006 & November & Allow gay marriage & Pew \\
\hline 2006 & June & Ban flag burning & Gallup \\
\hline 2006 & June & Death penalty & $\mathrm{ABC}$ \\
\hline 2006 & May & Death penalty & Gallup \\
\hline 2006 & various & Death penalty & GSS \\
\hline 2006 & various & Gay marriage & GSS \\
\hline 2006 & July & Gay marriage amendment & Pew \\
\hline 2006 & July & Gay marriage amendment & Pew \\
\hline 2006 & June & Gay marriage amendment & Pew \\
\hline 2006 & June & Gay marriage amendment & Pew \\
\hline 2006 & April & Immigration reform & $\mathrm{ABC}$ \\
\hline
\end{tabular}


Survey Text A12 Continued from previous page

\begin{tabular}{|c|c|c|c|}
\hline Year & Month & Item & Organization \\
\hline 2006 & April & Immigration reform & Pew \\
\hline 2006 & April & Immigration reform & CBS \\
\hline 2006 & June & Immigration reform & Pew \\
\hline 2006 & May & Immigration reform & CBS \\
\hline 2006 & October & Immigration reform & Pew \\
\hline 2006 & April & Immigration reform (Senate bill) & $\mathrm{ABC}$ \\
\hline 2006 & April & Immigration reform (Senate bill) & CBS \\
\hline 2006 & April & Immigration reform (Senate bill) & Pew \\
\hline 2006 & April & Immigration reform (Senate bill) & Gallup \\
\hline 2006 & May & Immigration reform (Senate bill) & Gallup \\
\hline 2006 & October & Immigration reform (Senate bill) & Pew \\
\hline 2006 & various & Legal abortion after rape & GSS \\
\hline 2006 & various & Legal abortion for any reason & GSS \\
\hline 2006 & various & Permit required to own gun & GSS \\
\hline 2006 & July & Stem cell research & Gallup \\
\hline 2007 & August & Abortion legal (v2) & Pew \\
\hline 2007 & November & Abortion legal (v2) & Pew \\
\hline 2007 & October & Abortion legal (v2) & Pew \\
\hline 2007 & August & Allow gay marriage & Pew \\
\hline 2007 & January & Allow gay marriage & Pew \\
\hline 2007 & November & Allow gay marriage & Pew \\
\hline 2007 & September & Allow gays to adopt children & Gallup \\
\hline 2007 & April & Assault weapon ban & $\mathrm{ABC}$ \\
\hline 2007 & December & Death penalty & $\mathrm{ABC}$ \\
\hline 2007 & April & Immigration reform (Senate bill) & $\mathrm{ABC}$ \\
\hline 2007 & December & Immigration reform (Senate bill) & Pew \\
\hline 2007 & January & Immigration reform (Senate bill) & Pew \\
\hline 2007 & June & Immigration reform (Senate bill) & CBS \\
\hline 2007 & June & Immigration reform (Senate bill) & Pew \\
\hline 2007 & March & Immigration reform (Senate bill) & Gallup \\
\hline 2007 & May & Immigration reform (Senate bill) & $\mathrm{ABC}$ \\
\hline 2007 & May & Immigration reform (Senate bill) & CBS \\
\hline 2007 & October & Immigration reform (Senate bill) & $\mathrm{ABC}$ \\
\hline 2007 & April & Stem cell research & Gallup \\
\hline 2007 & April & Stem cell research & $\mathrm{ABC}$ \\
\hline 2007 & January & Stem cell research & $\mathrm{ABC}$ \\
\hline 2008 & August & Abortion legal (v2) & Pew \\
\hline 2008 & October & Abortion legal (v2) & Pew \\
\hline 2008 & October & Abortion legal (v3) & ANES \\
\hline 2008 & August & Allow gay marriage & Pew \\
\hline 2008 & June & Allow gay marriage & Pew \\
\hline 2008 & May & Allow gay marriage & Pew \\
\hline 2008 & August & Civil unions & Pew \\
\hline 2008 & May & Civil unions & Pew \\
\hline 2008 & various & Death penalty & GSS \\
\hline 2008 & various & Gay marriage & GSS \\
\hline 2008 & October & Laws to protect gays & ANES \\
\hline 2008 & various & Legal abortion after rape & GSS \\
\hline 2008 & various & Legal abortion for any reason & GSS \\
\hline 2008 & various & Permit required to own gun & GSS \\
\hline 2009 & July & Abortion legal & Gallup \\
\hline 2009 & April & Abortion legal (v2) & Pew \\
\hline 2009 & August & Abortion legal (v2) & Pew \\
\hline 2009 & April & Allow gay marriage & Pew \\
\hline 2009 & April & Assault weapon ban & CBS \\
\hline 2009 & April & Civil unions & Pew \\
\hline 2009 & March & Gays in military & Pew \\
\hline 2009 & January & Legalize marijuana & CBS \\
\hline 2009 & July & Legalize marijuana & CBS \\
\hline 2010 & January & Allow gay marriage & Pew \\
\hline 2010 & May & Death penalty & CBS \\
\hline 2010 & various & Death penalty & GSS \\
\hline 2010 & various & Gay marriage & GSS \\
\hline 2010 & August & Gays in military & CBS \\
\hline 2010 & August & Gays in military & CBS \\
\hline
\end{tabular}


Survey Text A12 Continued from previous page

\begin{tabular}{|c|c|c|c|}
\hline Year & Month & Item & Organization \\
\hline 2010 & December & Gays in military & CBS \\
\hline 2010 & December & Gays in military & Pew \\
\hline 2010 & December & Gays in military & $\mathrm{ABC}$ \\
\hline 2010 & February & Gays in military & $\mathrm{ABC}$ \\
\hline 2010 & February & Gays in military & Pew \\
\hline 2010 & November & Gays in military & CBS \\
\hline 2010 & October & Gays in military & CBS \\
\hline 2010 & October & Gays in military & ANES \\
\hline 2010 & May & Law protecting gay from discrimination & CBS \\
\hline 2010 & May & Law protecting gay from discrimination & CBS \\
\hline 2010 & various & Legal abortion after rape & GSS \\
\hline 2010 & various & Legal abortion for any reason & GSS \\
\hline 2010 & April & Legalize marijuana & CBS \\
\hline 2010 & January & Legalize marijuana & $\mathrm{ABC}$ \\
\hline 2010 & March & Legalize marijuana & Pew \\
\hline 2010 & October & Legalize marijuana & $\mathrm{ABC}$ \\
\hline 2010 & various & Permit required to own gun & GSS \\
\hline 2011 & July & Abortion legal & Gallup \\
\hline 2011 & June & Abortion legal & Gallup \\
\hline 2011 & March & Abortion legal (v2) & Pew \\
\hline 2011 & November & Abortion legal (v2) & Pew \\
\hline 2011 & October & Abortion legal (v2) & Pew \\
\hline 2011 & January & Assault weapon ban & $\mathrm{CNN}$ \\
\hline 2011 & January & Assault weapon ban & CBS \\
\hline 2011 & November & Death penalty & Pew \\
\hline 2011 & October & Death penalty & Pew \\
\hline 2011 & April & Legalize marijuana & $\mathrm{CNN}$ \\
\hline 2012 & April & Abortion legal (v2) & Pew \\
\hline 2012 & August & Abortion legal (v2) & Pew \\
\hline 2012 & October & Abortion legal (v2) & Pew \\
\hline 2012 & October & Abortion legal (v3) & ANES \\
\hline 2012 & April & Allow gay marriage & Pew \\
\hline 2012 & August & Allow gay marriage & Pew \\
\hline 2012 & August & Assault weapon ban & $\mathrm{CNN}$ \\
\hline 2012 & December & Assault weapon ban & $\mathrm{CNN}$ \\
\hline 2012 & December & Assault weapon ban & Gallup \\
\hline 2012 & December & Death penalty & Gallup \\
\hline 2012 & October & Laws to protect gays & ANES \\
\hline 2013 & July & Abortion legal (v2) & Pew \\
\hline 2013 & March & Allow gay marriage & Pew \\
\hline 2013 & May & Allow gay marriage & Pew \\
\hline 2013 & April & Assault weapon ban & Gallup \\
\hline 2013 & April & Assault weapon ban & $\mathrm{ABC}$ \\
\hline 2013 & April & Assault weapon ban & $\mathrm{CNN}$ \\
\hline 2013 & April & Assault weapon ban & $\mathrm{ABC}$ \\
\hline 2013 & January & Assault weapon ban & $\mathrm{CNN}$ \\
\hline 2013 & January & Assault weapon ban & $\mathrm{ABC}$ \\
\hline 2013 & January & Assault weapon ban & Pew \\
\hline 2013 & March & Assault weapon ban & $\mathrm{ABC}$ \\
\hline 2013 & May & Assault weapon ban & Pew \\
\hline 2013 & February & Death penalty & CBS \\
\hline 2013 & May & Law protecting gay from discrimination & PRRI \\
\hline 2013 & December & Legalize marijuana & ReasonRupe \\
\hline 2014 & March & Abortion legal (v2) & Pew \\
\hline 2014 & September & Abortion legal (v2) & Pew \\
\hline 2014 & June & Allow gay marriage & $\mathrm{ABC}$ \\
\hline 2014 & March & Allow gay marriage & Pew \\
\hline 2014 & March & Allow gay marriage & $\mathrm{ABC}$ \\
\hline 2014 & September & Allow gay marriage & Pew \\
\hline 2014 & April & Death penalty & Pew \\
\hline 2014 & June & Death penalty & $\mathrm{ABC}$ \\
\hline 2014 & May & Death penalty & CBS \\
\hline 2014 & March & Legalize marijuana & Pew \\
\hline
\end{tabular}


Table A13: Economic Domain - Survey Question Text

\begin{tabular}{|c|c|c|c|}
\hline Year & Month & Item & Organization \\
\hline 1936 & December & Allow regulations & Gallup \\
\hline 1936 & December & Governmnent should own banks & Gallup \\
\hline 1936 & December & Governmnent should own railroad industry & Gallup \\
\hline 1936 & December & Limit private wealth & Gallup \\
\hline 1936 & December & WPA wages & Gallup \\
\hline 1936 & November & Social security (v1) & Gallup \\
\hline 1937 & April & Abolish WPA & Gallup \\
\hline 1937 & April & Favor single large union & Gallup \\
\hline 1937 & April & Limit hours people can work & Gallup \\
\hline 1937 & April & Remove sit-ins by force & Gallup \\
\hline 1937 & August & Governmnent should own banks & Gallup \\
\hline 1937 & August & Govt aid for striking workers & Gallup \\
\hline 1937 & August & Limit hours people can work & Gallup \\
\hline 1937 & August & Minimum wage (v2) & Gallup \\
\hline 1937 & August & Regulations & Gallup \\
\hline 1937 & August & Regulations & Gallup \\
\hline 1937 & August & Unemployment benefits for striking workers & Gallup \\
\hline 1937 & December & Government should help poor & Gallup \\
\hline 1937 & December & Governmnent should own railroad industry & Gallup \\
\hline 1937 & December & Remove sit-ins by force & Gallup \\
\hline 1937 & January & Favor single large union & Gallup \\
\hline 1937 & January & Regulate business profits during wartime & Gallup \\
\hline 1937 & January & Social security (v1) & Gallup \\
\hline 1937 & January & Takeover businesses during wartime & Gallup \\
\hline 1937 & July & Governmnent should own banks & Gallup \\
\hline 1937 & July & Unions - closed shops & Gallup \\
\hline 1937 & June & Favor single large union & Gallup \\
\hline 1937 & June & Govt provide health care to poor & Gallup \\
\hline 1937 & June & Labor unions - general support & Gallup \\
\hline 1937 & June & Limit private wealth & Gallup \\
\hline 1937 & June & Tax on chain stores & Gallup \\
\hline 1937 & June & Tax on chain stores & Gallup \\
\hline 1937 & March & Allow regulations & Gallup \\
\hline 1937 & March & Favor single large union & Gallup \\
\hline 1937 & March & Remove sit-ins by force & Gallup \\
\hline 1937 & March & Remove sit-ins by force & Gallup \\
\hline 1937 & March & Remove sit-ins by force & Gallup \\
\hline 1937 & March & Sit down strikes illegal & Gallup \\
\hline 1937 & March & Sit down strikes illegal & Gallup \\
\hline 1937 & May & Limit hours people can work & Gallup \\
\hline 1937 & May & Minimum wage (v2) & Gallup \\
\hline 1937 & May & Tax on chain stores & Gallup \\
\hline 1937 & November & Committee sets minimum wage & Gallup \\
\hline 1937 & November & Minimum wage (v1) & Gallup \\
\hline 1938 & April & Increase govt. spending (1938) & Gallup \\
\hline 1938 & April & Minimum wage (v1) & Gallup \\
\hline 1938 & August & Old age pensions & Gallup \\
\hline 1938 & December & Approve hours & Gallup \\
\hline 1938 & December & Should be secretary of welfare & Gallup \\
\hline 1938 & February & Veterans pension (v1) & Gallup \\
\hline 1938 & January & Governmnent should own electricity industry & Gallup \\
\hline 1938 & January & Increase govt. spending (1938) & Gallup \\
\hline 1938 & January & Tax on chain stores & Gallup \\
\hline 1938 & January & Union reports & Gallup \\
\hline 1938 & July & Approve hours & Gallup \\
\hline 1938 & July & Government should help poor & Gallup \\
\hline 1938 & July & Governmnent should own railroad industry & Gallup \\
\hline 1938 & July & Increase govt. spending (1938) & Gallup \\
\hline 1938 & July & Social security (v1) & Gallup \\
\hline 1938 & June & Increase govt. spending (1938) & Gallup \\
\hline 1938 & March & Increase govt. spending (1938) & Gallup \\
\hline 1938 & March & Taxes vs spending & Gallup \\
\hline 1938 & May & Committee sets minimum wage & Gallup \\
\hline 1938 & May & Govt provide health care to poor & Gallup \\
\hline
\end{tabular}


Survey Text A13 Continued from previous page

\begin{tabular}{|c|c|c|c|}
\hline Year & Month & Item & Organization \\
\hline 1938 & May & Increase govt. spending (1938) & Gallup \\
\hline 1938 & May & Regulated for big businesses & Gallup \\
\hline 1938 & NA & Social security (v2) & Gallup \\
\hline 1938 & NA & Unemployment benefits for striking workers & Gallup \\
\hline 1938 & October & Labor unions - general support & Gallup \\
\hline 1939 & August & Labor unions - general support & Gallup \\
\hline 1939 & December & Rights to refuse to hire unions & Gallup \\
\hline 1939 & December & Wagner Labor Act & Gallup \\
\hline 1939 & December & WPA union & Gallup \\
\hline 1939 & February & Regulated for big businesses & Gallup \\
\hline 1939 & February & Sit down strikes illegal & Gallup \\
\hline 1939 & February & Wagner Labor Act & Gallup \\
\hline 1939 & January & Government spending on relief (1939) & Gallup \\
\hline 1939 & January & Increase old age pensions & Gallup \\
\hline 1939 & January & Increase old age pensions & Gallup \\
\hline 1939 & January & Old age pensions & Gallup \\
\hline 1939 & January & Social security (v2) & Gallup \\
\hline 1939 & July & Ban Strikes & Gallup \\
\hline 1939 & June & Increase govt. spending (1939) & Gallup \\
\hline 1939 & May & Abolish WPA & Gallup \\
\hline 1939 & May & Labor unions - general support & Gallup \\
\hline 1939 & May & Unions - closed shops & Gallup \\
\hline 1939 & May & Unions - union hops & Gallup \\
\hline 1939 & May & Workers rights to join unions & Gallup \\
\hline 1939 & November & Govt aid for striking workers & Gallup \\
\hline 1939 & November & Labor unions - general support & Gallup \\
\hline 1939 & November & Old age pensions & Gallup \\
\hline 1939 & November & Unemployment benefits for striking workers & Gallup \\
\hline 1939 & November & Workers rights to join unions & Gallup \\
\hline 1939 & October & Takeover businesses during wartime & Gallup \\
\hline 1940 & August & Governmnent should own electricity industry & Gallup \\
\hline 1940 & February & Reduce farm spending 30 percent & Gallup \\
\hline 1940 & February & Reduce public works spending 20 percent & Gallup \\
\hline 1940 & February & WPA union & Gallup \\
\hline 1940 & January & Government spending on relief (1940) & Gallup \\
\hline 1940 & January & Reduce farm spending 30 percent & Gallup \\
\hline 1940 & January & Reduce public works spending 20 percent & Gallup \\
\hline 1940 & January & Wagner Labor Act & Gallup \\
\hline 1940 & May & Labor unions - general support & Gallup \\
\hline 1940 & May & Labor unions - general support & Gallup \\
\hline 1940 & May & Regulate businesses (1940) & Gallup \\
\hline 1940 & May & Veterans pension (v1) & Gallup \\
\hline 1940 & October & Regulate businesses (1940) & Gallup \\
\hline 1940 & October & Regulate businesses (1940) & Gallup \\
\hline 1940 & October & Wagner Labor Act & Gallup \\
\hline 1941 & August & Forbid all strikes (vital industries) & Gallup \\
\hline 1941 & December & Forbid all strikes (vital industries) & Gallup \\
\hline 1941 & July & Old age pensions & Gallup \\
\hline 1941 & June & Labor unions - general support & Gallup \\
\hline 1941 & June & Regulate businesses (1941) & Gallup \\
\hline 1941 & March & Rights to refuse to hire unions & Gallup \\
\hline 1941 & May & Forbid all strikes (vital industries) & Gallup \\
\hline 1941 & November & Forbid all strikes (vital industries) & Gallup \\
\hline 1941 & November & Unions - closed shops & Gallup \\
\hline 1941 & October & Forbid all strikes (vital industries) & Gallup \\
\hline 1941 & October & Government workers can strikes & Gallup \\
\hline 1941 & October & Labor unions - general support & Gallup \\
\hline 1941 & October & Unions - closed shops & Gallup \\
\hline 1941 & October & Unions - union hops & Gallup \\
\hline 1941 & September & Unions - elect director & Gallup \\
\hline 1942 & April & Abolish CCC & Gallup \\
\hline 1942 & April & Over time & Gallup \\
\hline 1942 & December & Forbid all strikes (non-vital industries) & Gallup \\
\hline 1942 & December & Forbid all strikes (vital industries) & Gallup \\
\hline 1942 & December & Limit executives income & Gallup \\
\hline
\end{tabular}


Survey Text A13 Continued from previous page

\begin{tabular}{|c|c|c|c|}
\hline Year & Month & Item & Organization \\
\hline 1942 & December & Limit income & Gallup \\
\hline 1942 & December & Limit movie stars income & Gallup \\
\hline 1942 & December & Union reports & Gallup \\
\hline 1942 & March & Forbid all strikes (vital industries) & Gallup \\
\hline 1942 & March & Union reports & Gallup \\
\hline 1942 & May & Limit income & Gallup \\
\hline 1942 & September & Forbid all strikes (vital industries) & Gallup \\
\hline 1943 & February & Unemployment & Gallup \\
\hline 1943 & June & $\begin{array}{l}\text { Govt should prevent labor unions from forcing employers to } \\
\text { hire more workers than are needed }\end{array}$ & Gallup \\
\hline 1943 & June & $\begin{array}{l}\text { Govt should prevent labor unions from forcing employers to } \\
\text { hire more workers than are needed }\end{array}$ & Gallup \\
\hline 1943 & May & Forbid all strikes (vital industries) & Gallup \\
\hline 1943 & May & Labor unions - general support & Gallup \\
\hline 1943 & NA & Govt provide health care to poor & Gallup \\
\hline 1943 & NA & Social security (v7) & Gallup \\
\hline 1943 & NA & Subsidize education expenses for poor & Gallup \\
\hline 1943 & November & Forbid all strikes (vital industries) & Gallup \\
\hline 1943 & November & Union reports & Gallup \\
\hline 1944 & August & Unemployment insurance & Gallup \\
\hline 1944 & December & Social security (v3) & Gallup \\
\hline 1944 & December & Social security (v4) & Gallup \\
\hline 1944 & December & Social security (v5) & Gallup \\
\hline 1944 & December & Social security (v6) & Gallup \\
\hline 1944 & January & Forbid all strikes (vital industries) & Gallup \\
\hline 1944 & January & $\begin{array}{l}\text { Govt should prevent labor unions from forcing employers to } \\
\text { hire more workers than are needed }\end{array}$ & Gallup \\
\hline 1944 & May & Forbid all strikes (vital industries) & Gallup \\
\hline 1944 & NA & Social security (v7) & Gallup \\
\hline 1945 & August & Government-run health care (v1) & Gallup \\
\hline 1945 & August & Minimum wage $(65$ cents $)$ & Gallup \\
\hline 1945 & August & Should be secretary of welfare & Gallup \\
\hline 1945 & December & $\begin{array}{l}\text { Govt should prevent labor unions from forcing employers to } \\
\text { hire more workers than are needed }\end{array}$ & Gallup \\
\hline 1945 & July & Forbid all strikes & Gallup \\
\hline 1945 & July & Right to work & Gallup \\
\hline 1945 & July & Unions - closed shops & Gallup \\
\hline 1945 & July & Unions - union hops & Gallup \\
\hline 1945 & June & Fund cancer research & Gallup \\
\hline 1945 & June & Governmnent should own electricity industry & Gallup \\
\hline 1945 & June & Governmnent should own railroad industry & Gallup \\
\hline 1945 & June & Taxes to pay for cancer research & Gallup \\
\hline 1945 & June & Unemployment & Gallup \\
\hline 1945 & March & Forbid all strikes (vital industries) & Gallup \\
\hline 1945 & May & Military plans vs private business & Gallup \\
\hline 1945 & November & Truman health care bill (knowledgeable) & Gallup \\
\hline 1945 & October & Atomic energy & Gallup \\
\hline 1945 & October & Ceiling on rents & Gallup \\
\hline 1945 & October & Ration meat & Gallup \\
\hline 1945 & October & Unemployment benefits & Gallup \\
\hline 1945 & September & Committee sets minimum wage & Gallup \\
\hline 1945 & September & Governmnent should own banks & Gallup \\
\hline 1945 & September & Governmnent should own coal industry & Gallup \\
\hline 1945 & September & Governmnent should own electricity industry & Gallup \\
\hline 1945 & September & Governmnent should own railroad industry & Gallup \\
\hline 1945 & September & Minimum wage (60 cents) & Gallup \\
\hline 1945 & September & Minimum wage (65 cents) & Gallup \\
\hline 1945 & September & Unemployment benefits & Gallup \\
\hline 1946 & April & Ceiling on rents & Gallup \\
\hline 1946 & April & Government-run health care (v2) & Gallup \\
\hline 1946 & April & Government-run health care (v3) & Gallup \\
\hline 1946 & April & Military plans vs private business & Gallup \\
\hline 1946 & August & Ration meat & Gallup \\
\hline 1946 & February & Ban Strikes & Gallup \\
\hline 1946 & February & Labor unions - general support & Gallup \\
\hline
\end{tabular}


Survey Text A13 Continued from previous page

\begin{tabular}{|c|c|c|c|}
\hline Year & Month & Item & Organization \\
\hline 1946 & February & Military plans vs private business & Gallup \\
\hline 1946 & January & Max tax rate of 50 percent & Gallup \\
\hline 1946 & January & Price controls & Gallup \\
\hline 1946 & May & Ban Strikes & Gallup \\
\hline 1946 & May & Fund cancer research & Gallup \\
\hline 1946 & May & Unemployment benefits for striking workers & Gallup \\
\hline 1946 & November & Right to work & Gallup \\
\hline 1946 & November & Tax decrease (1946) & Gallup \\
\hline 1946 & November & Union reports & Gallup \\
\hline 1946 & November & Unions - closed shops & Gallup \\
\hline 1946 & November & Unions - union hops & Gallup \\
\hline 1946 & October & Ceiling on rents & Gallup \\
\hline 1946 & October & Minimum wage (65 cents) & Gallup \\
\hline 1946 & October & Ration meat & Gallup \\
\hline 1946 & October & Tax decrease (1946) & Gallup \\
\hline 1946 & September & Ceiling on rents & Gallup \\
\hline 1946 & September & Ration meat & Gallup \\
\hline 1946 & September & Teachers allowed to form unions & Gallup \\
\hline 1947 & April & Tax decrease (1947) & Gallup \\
\hline 1947 & August & Taft Hartley bill (v2) & Gallup \\
\hline 1947 & February & Atomic energy & Gallup \\
\hline 1947 & February & Tax decrease (1947) & Gallup \\
\hline 1947 & January & Ban Strikes & Gallup \\
\hline 1947 & January & Governmnent should own banks & Gallup \\
\hline 1947 & January & Governmnent should own coal industry & Gallup \\
\hline 1947 & January & Governmnent should own electricity industry & Gallup \\
\hline 1947 & January & Governmnent should own railroad industry & Gallup \\
\hline 1947 & January & Jurisdictional strikes & Gallup \\
\hline 1947 & July & Forbid all strikes & Gallup \\
\hline 1947 & July & Labor unions - general support & Gallup \\
\hline 1947 & July & Taft Hartley bill (v1) & Gallup \\
\hline 1947 & July & Taft Hartley bill (v2) & Gallup \\
\hline 1947 & June & Governmnent should own electricity industry & Gallup \\
\hline 1947 & March & Ban Strikes & Gallup \\
\hline 1947 & March & Government workers can strikes & Gallup \\
\hline 1947 & March & Governmnent should own electricity industry & Gallup \\
\hline 1947 & May & Ban Strikes & Gallup \\
\hline 1947 & May & Governmnent should own banks & Gallup \\
\hline 1947 & May & Governmnent should own coal industry & Gallup \\
\hline 1947 & May & Governmnent should own electricity industry & Gallup \\
\hline 1947 & May & Governmnent should own railroad industry & Gallup \\
\hline 1947 & May & Max tax rate of 50 percent & Gallup \\
\hline 1947 & May & Minimum wage ( 65 cents) & Gallup \\
\hline 1947 & May & Should be secretary of welfare & Gallup \\
\hline 1947 & May & Tax decrease (1947) & Gallup \\
\hline 1947 & November & Max tax rate of 50 percent & Gallup \\
\hline 1947 & November & Taft Hartley bill (v4) & Gallup \\
\hline 1948 & April & Ration some products & Gallup \\
\hline 1948 & December & Federal aid for schools & Gallup \\
\hline 1948 & December & Governmnent should own banks & Gallup \\
\hline 1948 & December & Governmnent should own coal industry & Gallup \\
\hline 1948 & December & Governmnent should own electricity industry & Gallup \\
\hline 1948 & December & Governmnent should own railroad industry & Gallup \\
\hline 1948 & December & Labor unions - general support & Gallup \\
\hline 1948 & December & Social security (v3) & Gallup \\
\hline 1948 & December & Social security (v4) & Gallup \\
\hline 1948 & December & Social security (v5) & Gallup \\
\hline 1948 & December & Social security (v6) & Gallup \\
\hline 1948 & February & Ceiling on rents & Gallup \\
\hline 1948 & January & Laws regulating unions are too strict & Gallup \\
\hline 1948 & January & Minimum wage ( 75 cents) & Gallup \\
\hline 1948 & January & Ration some products & Gallup \\
\hline 1948 & January & Taft Hartley bill (v2) & Gallup \\
\hline 1948 & January & Taft Hartley bill (v4) & Gallup \\
\hline 1948 & July & Minimum wage ( 75 cents) & Gallup \\
\hline
\end{tabular}


Survey Text A13 Continued from previous page

\begin{tabular}{|c|c|c|c|}
\hline Year & Month & Item & Organization \\
\hline 1948 & July & Ration some products & Gallup \\
\hline 1948 & July & Taft Hartley bill (v2) & Gallup \\
\hline 1948 & July & Taft Hartley bill (v3) & Gallup \\
\hline 1948 & July & Taft Hartley bill (v4) & Gallup \\
\hline 1948 & May & Federal aid for schools & Gallup \\
\hline 1948 & May & Fund heart disease research & Gallup \\
\hline 1948 & May & Governmnent should own banks & Gallup \\
\hline 1948 & May & Governmnent should own coal industry & Gallup \\
\hline 1948 & May & Governmnent should own electricity industry & Gallup \\
\hline 1948 & May & Governmnent should own railroad industry & Gallup \\
\hline 1948 & May & Laws regulating unions are too strict & Gallup \\
\hline 1948 & May & Taft Hartley bill (v2) & Gallup \\
\hline 1948 & May & Taft Hartley bill (v4) & Gallup \\
\hline 1948 & November & Ceiling on rents & Gallup \\
\hline 1948 & November & Laws regulating unions are too strict & Gallup \\
\hline 1948 & November & Minimum wage ( 75 cents) & Gallup \\
\hline 1948 & November & Ration some products & Gallup \\
\hline 1948 & November & Slum clearance & Gallup \\
\hline 1948 & November & Taft Hartley bill (v1) & Gallup \\
\hline 1948 & November & Taft Hartley bill (v2) & Gallup \\
\hline 1948 & November & Taft Hartley bill (v2) & Gallup \\
\hline 1948 & November & Taft Hartley bill ( $\mathrm{v} 4)$ & Gallup \\
\hline 1948 & November & Taft Hartley bill (v4) & Gallup \\
\hline 1949 & April & Taft Hartley bill (v1) & Gallup \\
\hline 1949 & April & Taft Hartley bill (v4) & Gallup \\
\hline 1949 & February & $\begin{array}{l}\text { Govt should prevent labor unions from forcing employers to } \\
\text { hire more workers than are needed }\end{array}$ & Gallup \\
\hline 1949 & February & Jurisdictional strikes & Gallup \\
\hline 1949 & February & Right to work & Gallup \\
\hline 1949 & February & Unions - closed shops & Gallup \\
\hline 1949 & February & Unions - right to strike & Gallup \\
\hline 1949 & February & Unions - union hops & Gallup \\
\hline 1949 & January & Taft Hartley bill (v1) & Gallup \\
\hline 1949 & January & Taft Hartley bill (v2) & Gallup \\
\hline 1949 & January & Taft Hartley bill (v4) & Gallup \\
\hline 1949 & January & Truman health care bill & Gallup \\
\hline 1949 & January & Union reports & Gallup \\
\hline 1949 & January & Unions - closed shops & Gallup \\
\hline 1949 & July & Should be secretary of welfare & Gallup \\
\hline 1949 & July & Unemployment benefits for striking workers & Gallup \\
\hline 1949 & June & Taft Hartley bill (v4) & Gallup \\
\hline 1949 & March & Truman health care bill (knowledgeable) & Gallup \\
\hline 1949 & March & Veterans pension (v2) & Gallup \\
\hline 1949 & May & Federal aid for schools & Gallup \\
\hline 1949 & May & Minimum wage (60 cents) & Gallup \\
\hline 1949 & May & Minimum wage (65 cents) & Gallup \\
\hline 1949 & May & Taxes & Gallup \\
\hline 1949 & May & Truman health care bill & Gallup \\
\hline 1949 & November & Laws regulating unions are too strict & Gallup \\
\hline 1949 & November & Taft Hartley bill (v2) & Gallup \\
\hline 1949 & November & Taft Hartley bill (v3) & Gallup \\
\hline 1949 & November & Taft Hartley bill (v4) & Gallup \\
\hline 1949 & November & Truman health care bill (knowledgeable) & Gallup \\
\hline 1949 & October & Raise taxes & Gallup \\
\hline 1949 & October & Taft Hartley bill (v3) & Gallup \\
\hline 1949 & October & Truman health care bill & Gallup \\
\hline 1949 & September & Unions are monopoly & Gallup \\
\hline 1950 & February & Unions are monopoly & Gallup \\
\hline 1950 & January & Taxes & Gallup \\
\hline 1950 & July & Forbid all strikes (vital industries) & Gallup \\
\hline 1950 & June & Taft Hartley bill (v3) & Gallup \\
\hline 1950 & March & Spending on public works & Gallup \\
\hline 1950 & March & Spending on social welfare & Gallup \\
\hline 1950 & March & Taft Hartley bill (v3) & Gallup \\
\hline 1950 & November & Truman health care bill & Gallup \\
\hline
\end{tabular}


Survey Text A13 Continued from previous page

\begin{tabular}{|c|c|c|c|}
\hline Year & Month & Item & Organization \\
\hline 1950 & October & Taft Hartley bill (v3) & Gallup \\
\hline 1950 & October & Truman health care bill & Gallup \\
\hline 1951 & August & Maximum tax rate of 25 percent & Gallup \\
\hline 1951 & August & Police allowed to form unions & Gallup \\
\hline 1951 & December & Labor unions - general support & Gallup \\
\hline 1951 & June & Price controls & Gallup \\
\hline 1951 & June & Price freeze (early 1950s) & Gallup \\
\hline 1951 & March & Reconstruction Finance Corporate & Gallup \\
\hline 1952 & December & Price controls & Gallup \\
\hline 1952 & December & Price freeze (early 1950s) & Gallup \\
\hline 1952 & July & Taft Hartley bill (v3) & Gallup \\
\hline 1952 & May & Laws regulating unions are too strict & Gallup \\
\hline 1952 & May & Maximum tax rate of 25 percent & Gallup \\
\hline 1952 & May & Taft Hartley bill (v2) & Gallup \\
\hline 1952 & May & Taft Hartley bill (v4) & Gallup \\
\hline 1952 & NA & Government should do more & Gallup \\
\hline 1952 & November & Should be secretary of welfare & Gallup \\
\hline 1952 & October & Taft Hartley bill (v2) & Gallup \\
\hline 1952 & October & Taft Hartley bill (v4) & Gallup \\
\hline 1952 & October & Truman health care bill & Gallup \\
\hline 1952 & October & Truman health care bill & Gallup \\
\hline 1952 & September & Truman health care bill & Gallup \\
\hline 1952 & September & Truman health care bill & Gallup \\
\hline 1953 & April & Tax to pay for highways & Gallup \\
\hline 1953 & December & Ban stikes by communications workers & Gallup \\
\hline 1953 & February & Maximum tax rate of 25 percent & Gallup \\
\hline 1953 & November & 35 hour work week & Gallup \\
\hline 1953 & November & Max tax rate on $50 \mathrm{k}$ in income & Gallup \\
\hline 1953 & October & Laws regulating unions are too strict & Gallup \\
\hline 1953 & September & Governmnent should own coal industry & Gallup \\
\hline 1953 & September & Governmnent should own electricity industry & Gallup \\
\hline 1953 & September & Minimum wage ( 1 dollar) & Gallup \\
\hline 1954 & December & Minimum wage ( 1 dollar and 25 cents) & Gallup \\
\hline 1954 & February & Union stikes - secret vote & Gallup \\
\hline 1954 & June & Fund heart disease research & Gallup \\
\hline 1954 & March & Fund cancer research & Gallup \\
\hline 1954 & March & Tax to pay for highways & Gallup \\
\hline 1954 & May & Public works & Gallup \\
\hline 1955 & August & Build big dams & Gallup \\
\hline 1955 & December & Federal aid for schools & Gallup \\
\hline 1955 & February & Federal aid for schools & NORC \\
\hline 1955 & February & Government pay for health care & NORC \\
\hline 1955 & February & Governmnent should own banks & NORC \\
\hline 1955 & February & Governmnent should own electricity industry & NORC \\
\hline 1955 & February & Governmnent should own railroad industry & NORC \\
\hline 1955 & February & Maximum salary & NORC \\
\hline 1955 & February & Regulation of business & NORC \\
\hline 1955 & February & Right to work & NORC \\
\hline 1955 & January & 35 hour work week & Gallup \\
\hline 1955 & January & Maximum tax rate of 35 percent & Gallup \\
\hline 1955 & January & Public works & Gallup \\
\hline 1955 & July & Build big dams & Gallup \\
\hline 1955 & July & Tax to pay for school & Gallup \\
\hline 1955 & September & Bonus for babies & Gallup \\
\hline 1956 & April & Build new highways & Gallup \\
\hline 1956 & February & Max tax rate on $50 \mathrm{k}$ in income & Gallup \\
\hline 1956 & June & Regulate monopolies & Gallup \\
\hline 1956 & March & Fine for littering & Gallup \\
\hline 1956 & May & Higher taxes on big companies & Gallup \\
\hline 1956 & November & Drivers should be required to get physical examination & Gallup \\
\hline 1956 & November & Summer vacation for schools & Gallup \\
\hline 1956 & October & Federal aid for schools & ANES \\
\hline 1956 & October & Guaranteed jobs (likert) & ANES \\
\hline 1956 & October & Privatize electricity companies & ANES \\
\hline 1956 & October & Subsidize health care & ANES \\
\hline
\end{tabular}


Survey Text A13 Continued from previous page

\begin{tabular}{|c|c|c|c|}
\hline Year & Month & Item & Organization \\
\hline 1956 & October & Universal healthcare (ANES- v1) & ANES \\
\hline 1957 & April & Max tax rate on $50 \mathrm{k}$ in income & Gallup \\
\hline 1957 & April & Unions accounting should be public & Gallup \\
\hline 1957 & January & Federal aid for schools & Gallup \\
\hline 1957 & January & Minimum wage ( 1 dollar and 25 cents) & Gallup \\
\hline 1957 & July & Federal aid for schools & Gallup \\
\hline 1957 & July & Four day work week & Gallup \\
\hline 1957 & July & Right to work & Gallup \\
\hline 1957 & June & Max tax rate of $25-35$ percent & Gallup \\
\hline 1958 & April & Tax cuts versus spending & Gallup \\
\hline 1958 & January & Free college tuition & Gallup \\
\hline 1958 & May & Tax cuts versus spending & Gallup \\
\hline 1958 & October & Federal aid for schools & ANES \\
\hline 1958 & October & Guaranteed jobs (likert) & ANES \\
\hline 1958 & October & Price freeze (late 1950s) & ANES \\
\hline 1958 & October & Privatize electricity companies & ANES \\
\hline 1958 & October & Unions accounting should be public & Gallup \\
\hline 1959 & January & Police unions & Gallup \\
\hline 1959 & January & Teacher unions & Gallup \\
\hline 1959 & January & Laws regulating unions are too strict & Gallup \\
\hline 1959 & January & Same pay for 35 hour work week as 40 hour week & Gallup \\
\hline 1959 & May & Price freeze (late 1950s) & Gallup \\
\hline 1959 & November & Special court for union disputes & Gallup \\
\hline 1959 & October & Youth CCC & Gallup \\
\hline 1960 & April & Govt should fix automobile prices & Gallup \\
\hline 1960 & April & Govt should fix drug prices & Gallup \\
\hline 1960 & January & Federal aid for schools & Gallup \\
\hline 1960 & October & Guaranteed jobs (likert) & ANES \\
\hline 1960 & October & Privatize electricity companies & ANES \\
\hline 1960 & October & Subsidize health care & ANES \\
\hline 1960 & October & Universal healthcare (ANES- v1) & ANES \\
\hline 1961 & December & Limit corporate profits & NORC \\
\hline 1961 & December & Maximum salary & NORC \\
\hline 1961 & December & Regulation of business & NORC \\
\hline 1961 & December & Right to work & NORC \\
\hline 1961 & December & Unions should be legal & NORC \\
\hline 1961 & February & Federal aid for schools & Gallup \\
\hline 1961 & February & Minimum wage (1961) & Gallup \\
\hline 1961 & May & Medicare should be passed & Gallup \\
\hline 1961 & May & Laws regulating unions are too strict & Gallup \\
\hline 1961 & May & $\begin{array}{l}\text { Favor allowing unions to require more workers than are needed } \\
\text { for a job }\end{array}$ & Gallup \\
\hline 1961 & November & Welfare & Gallup \\
\hline 1961 & October & Mandatory automobile insurance & Gallup \\
\hline 1961 & October & Welfare & Gallup \\
\hline 1961 & September & $\begin{array}{l}\text { Favor allowing unions to require more workers than are needed } \\
\text { for a job }\end{array}$ & Gallup \\
\hline 1962 & February & 35 hour work week & Gallup \\
\hline 1962 & July & Laws regulating unions are too strict & Gallup \\
\hline 1962 & July & Income tax cut versus reduce deficitn & Gallup \\
\hline 1962 & July & 35 hour work week & Gallup \\
\hline 1962 & June & Medicare should be passed & Gallup \\
\hline 1962 & March & Medicare should be passed & Gallup \\
\hline 1962 & March & $\begin{array}{l}\text { Favor allowing unions to require more workers than are needed } \\
\text { for a job }\end{array}$ & Gallup \\
\hline 1962 & October & Federal aid for schools & ANES \\
\hline 1962 & October & Price freeze (late 1950s) & ANES \\
\hline 1962 & October & Universal healthcare (ANES- v1) & ANES \\
\hline 1963 & April & Income tax cut versus reduce deficitn & Gallup \\
\hline 1963 & January & Ban stikes by communications workers & Gallup \\
\hline 1963 & January & Ban stikes by transportation workers & Gallup \\
\hline 1963 & January & Income tax & Gallup \\
\hline 1963 & July & $\begin{array}{l}\text { Favor allowing unions to require more workers than are needed } \\
\text { for a job }\end{array}$ & Gallup \\
\hline 1963 & May & Lottery & Gallup \\
\hline
\end{tabular}


Survey Text A13 Continued from previous page

\begin{tabular}{|c|c|c|c|}
\hline Year & Month & Item & Organization \\
\hline 1964 & April & Lottery & Gallup \\
\hline 1964 & November & Welfare - require 60 day residency & Gallup \\
\hline 1964 & October & Guaranteed jobs (non-likert) & ANES \\
\hline 1964 & October & Universal healthcare (ANES- v1) & ANES \\
\hline 1964 & October & Federal aid for schools (v2) & Gallup \\
\hline 1964 & October & Medicare should be passed & Gallup \\
\hline 1964 & October & Medicare should be passed & NORC \\
\hline 1964 & October & Medicare should be passed & NORC \\
\hline 1964 & September & Federal aid for schools (v2) & Gallup \\
\hline 1964 & September & Medicare should be passed & Gallup \\
\hline 1965 & August & Minimum wage ( 1 dollar and 50 cents) & Gallup \\
\hline 1965 & February & Federal aid for schools (v3) & Gallup \\
\hline 1965 & May & Build power lines underground & Gallup \\
\hline 1965 & May & Taxes for new power lines & Gallup \\
\hline 1965 & May & Require people to join unions if in unionized business & Gallup \\
\hline 1965 & October & Allow policy strikes & Gallup \\
\hline 1965 & October & Allow teacher strikes & Gallup \\
\hline 1965 & October & Police allowed to form unions & Gallup \\
\hline 1965 & October & Teachers allowed to form unions & Gallup \\
\hline 1965 & October & Require people to join unions if in unionized business & Gallup \\
\hline 1965 & September & Minimum annual income & Gallup \\
\hline 1965 & September & Require people to join unions if in unionized business & Gallup \\
\hline 1966 & August & Ban stikes by communications workers & Gallup \\
\hline 1966 & August & Ban stikes by transportation workers & Gallup \\
\hline 1966 & December & Return 3 percent of federal revenue to states & Gallup \\
\hline 1966 & January & Minimum wage ( 1 dollar and 50 cents) (v2) & Gallup \\
\hline 1966 & January & Laws regulating unions are too strict & Gallup \\
\hline 1966 & January & Same pay for 35 hour work week as 40 hour week & Gallup \\
\hline 1966 & January & Require people to join unions if in unionized business & Gallup \\
\hline 1967 & April & Strikes - Govt. mediate after 21 days & Gallup \\
\hline 1967 & April & Return 3 percent of federal revenue to states & Gallup \\
\hline 1967 & June & Return 3 percent of federal revenue to states & Gallup \\
\hline 1967 & March & Require people to join unions if in unionized business & Gallup \\
\hline 1967 & November & Build power lines underground & Gallup \\
\hline 1968 & December & Allow teacher strikes & Gallup \\
\hline 1968 & December & Equalize welfare payments (v1) & Gallup \\
\hline 1968 & December & Guaranteed jobs (likert) & Gallup \\
\hline 1968 & December & Police allowed to form unions & Gallup \\
\hline 1968 & December & Strikes - Govt. mediate after 21 days & Gallup \\
\hline 1968 & December & Teachers allowed to form unions & Gallup \\
\hline 1968 & December & Return 3 percent of federal revenue to states & Gallup \\
\hline 1968 & February & Allow teacher strikes & Gallup \\
\hline 1968 & February & Teachers allowed to form unions & Gallup \\
\hline 1968 & January & Strikes - Govt. mediate after 21 days & Gallup \\
\hline 1968 & March & Guaranteed jobs (likert) & Gallup \\
\hline 1968 & November & Help unions & $\begin{array}{l}\text { Comparative } \\
\text { State Elections } \\
\text { Project }\end{array}$ \\
\hline 1968 & November & Increase social security benefits & $\begin{array}{l}\text { Comparative } \\
\text { State Elections } \\
\text { Project }\end{array}$ \\
\hline 1968 & November & Stop poverty programs & $\begin{array}{l}\text { Comparative } \\
\text { State Elections } \\
\text { Project }\end{array}$ \\
\hline 1968 & October & Guaranteed jobs (non-likert) & ANES \\
\hline 1968 & October & Universal healthcare (ANES- v1) & ANES \\
\hline 1969 & April & Food stamps & Gallup \\
\hline 1969 & January & Equalize welfare payments ( v2) & Gallup \\
\hline 1969 & January & Welfare costs & Gallup \\
\hline 1969 & January & $\begin{array}{l}\text { Favor allowing unions to require more workers than are needed } \\
\text { for a job }\end{array}$ & Gallup \\
\hline 1969 & June & Child care for the poor & Gallup \\
\hline 1970 & April & Guidance counselor in schools & Gallup \\
\hline 1970 & April & State taxes for education & Gallup \\
\hline 1970 & October & Inflation & ANES \\
\hline
\end{tabular}


Survey Text A13 Continued from previous page

\begin{tabular}{|c|c|c|c|}
\hline Year & Month & Item & Organization \\
\hline 1970 & October & Polluion & ANES \\
\hline 1970 & October & Universal healthcare (ANES- v2) & ANES \\
\hline 1971 & August & Mandatory drivers education & Gallup \\
\hline 1971 & January & National health insurance & Gallup \\
\hline 1971 & January & Return 3 percent of federal revenue to states & Gallup \\
\hline 1971 & November & College spending & Gallup \\
\hline 1971 & November & Price controls $(1971)$ & Gallup \\
\hline 1971 & October & Build power lines underground & Gallup \\
\hline 1972 & August & Price controls (1972) & Gallup \\
\hline 1972 & December & Spending vs taxes & Gallup \\
\hline 1972 & January & Price controls (1972) & Gallup \\
\hline 1972 & March & Price controls (1972) & Gallup \\
\hline 1972 & March & Strikes - Govt. mediate after 21 days & Gallup \\
\hline 1972 & October & Guaranteed jobs (multi-point scale) & ANES \\
\hline 1972 & October & Pollution & ANES \\
\hline 1972 & October & Universal healthcare (ANES- v2) & ANES \\
\hline 1973 & April & Price controls (1973) & Gallup \\
\hline 1973 & February & Government run railroads & Gallup \\
\hline 1973 & February & $\begin{array}{l}\text { Favor allowing unions to require more workers than are needed } \\
\text { for a job }\end{array}$ & Gallup \\
\hline 1973 & July & Utility bills vs pollution & Gallup \\
\hline 1973 & June & Require seat belts & Gallup \\
\hline 1973 & May & State taxes for education (v2) & Gallup \\
\hline 1974 & August & Price controls (mid-late 1970s) & Gallup \\
\hline 1974 & December & Price controls (mid-late 1970s) & Roper \\
\hline 1974 & May & Reduce school spending differences & Gallup \\
\hline 1974 & October & Guaranteed jobs (multi-point scale) & ANES \\
\hline 1974 & October & Five percent surtax on the rich & Gallup \\
\hline 1974 & October & Gas tax of 20 cents & Gallup \\
\hline 1974 & October & Price controls (mid-late 1970s) & Gallup \\
\hline 1974 & October & Freeze pollution control & Roper \\
\hline 1974 & October & Spending cuts & Roper \\
\hline 1975 & April & National health insurance & Roper \\
\hline 1975 & October & Allow policy strikes & Roper \\
\hline 1975 & October & Allow teacher strikes & Roper \\
\hline 1975 & October & National health insurance & Roper \\
\hline 1975 & September & Allow policy strikes & Gallup \\
\hline 1975 & various & Govt help poor & GSS \\
\hline 1975 & various & Govt help pay medical bills & GSS \\
\hline 1976 & April & Government size & CBS \\
\hline 1976 & December & Price controls (mid-late 1970s) & Gallup \\
\hline 1976 & June & Government size & CBS \\
\hline 1976 & March & Guaranteed jobs (likert) & CBS \\
\hline 1976 & March & Balance budget amendment & Gallup \\
\hline 1976 & May & Government size & CBS \\
\hline 1976 & May & Guaranteed jobs (likert) & CBS \\
\hline 1976 & November & Government size & CBS \\
\hline 1976 & October & Guaranteed jobs (multi-point scale) & ANES \\
\hline 1976 & October & Universal healthcare (ANES- v2) & ANES \\
\hline 1976 & October & Government size & CBS \\
\hline 1976 & October & Guaranteed jobs (likert) & CBS \\
\hline 1976 & October & National health insurance & Roper \\
\hline 1976 & September & Government size & CBS \\
\hline 1976 & September & National health insurance & CBS \\
\hline 1977 & August & Ban cigarette advertisements & Gallup \\
\hline 1977 & July & Guaranteed income of 2200 dollars & CBS \\
\hline 1977 & March & Guaranteed jobs (likert) & Time \\
\hline 1977 & October & Require seat belts & Gallup \\
\hline 1977 & September & National health insurance & Roper \\
\hline 1978 & August & Allow policy strikes & Gallup \\
\hline 1978 & August & Allow teacher strikes & Gallup \\
\hline 1978 & August & Allow policy strikes & Roper \\
\hline 1978 & August & Allow teacher strikes & Roper \\
\hline 1978 & December & Price controls (mid-late 1970s) & Gallup \\
\hline 1978 & January & Guaranteed jobs (likert) & CBS \\
\hline
\end{tabular}


Survey Text A13 Continued from previous page

\begin{tabular}{|c|c|c|c|}
\hline Year & Month & Item & Organization \\
\hline 1978 & January & Allow policy strikes & Gallup \\
\hline 1978 & January & Allow teacher strikes & Gallup \\
\hline 1978 & June & Balance budget amendment & Gallup \\
\hline 1978 & October & Guaranteed jobs (multi-point scale) & ANES \\
\hline 1978 & October & Universal healthcare (ANES- v2) & ANES \\
\hline 1978 & September & National health insurance & Roper \\
\hline 1978 & various & Govt reduce income differences between rich and poor & GSS \\
\hline 1979 & August & Price controls (mid-late 1970s) & Gallup \\
\hline 1979 & December & Balance budget amendment & Gallup \\
\hline 1979 & February & National health insurance & Roper \\
\hline 1979 & January & Government spending for the poor & CBS \\
\hline 1979 & January & Doctors at low cost & Gallup \\
\hline 1979 & May & Allow policy strikes & Gallup \\
\hline 1979 & May & Allow teacher strikes & Gallup \\
\hline 1979 & May & Price controls (mid-late 1970s) & Gallup \\
\hline 1979 & November & Gas tax & Gallup \\
\hline 1980 & April & Price controls (mid-late 1970s) & Roper \\
\hline 1980 & August & Unemployment & CBS \\
\hline 1980 & February & National health insurance & CBS \\
\hline 1980 & March & Government size & CBS \\
\hline 1980 & March & National health insurance & CBS \\
\hline 1980 & March & Nuclear power & CBS \\
\hline 1980 & March & Balance budget amendment & Gallup \\
\hline 1980 & March & Price controls (mid-late 1970s) & Time \\
\hline 1980 & May & Allow teacher strikes & Gallup \\
\hline 1980 & October & Guaranteed jobs (multi-point scale) & ANES \\
\hline 1980 & September & Income tax cut & CBS \\
\hline 1980 & September & Nuclear power & Gallup \\
\hline 1980 & September & Price controls (mid-late 1970s) & Gallup \\
\hline 1980 & various & Govt reduce income differences between rich and poor & GSS \\
\hline 1981 & April & National health insurance & CBS \\
\hline 1981 & April & Tax cuts & CBS \\
\hline 1981 & April & Balance budget amendment & Gallup \\
\hline 1981 & August & Allow policy strikes & Gallup \\
\hline 1981 & January & Income tax cut & CBS \\
\hline 1981 & January & Price controls (mid-late 1970s) & Gallup \\
\hline 1981 & June & Ban cigarette advertisements & Gallup \\
\hline 1981 & June & Price controls (mid-late 1970s) & Gallup \\
\hline 1981 & March & Tax cuts & LATimes \\
\hline 1981 & October & Environment & CBS \\
\hline 1981 & September & Balance budget amendment & Gallup \\
\hline 1982 & August & Balance budget amendment & Gallup \\
\hline 1982 & July & Require seat belts & Gallup \\
\hline 1982 & May & Eliminate tax cuts & CBS \\
\hline 1982 & May & Reduced spending & CBS \\
\hline 1982 & May & Balance budget amendment & Gallup \\
\hline 1982 & October & Guaranteed jobs (multi-point scale) & ANES \\
\hline 1982 & September & Environment & CBS \\
\hline 1983 & April & Nuclear power & $\mathrm{ABC}$ \\
\hline 1983 & April & Environment & CBS \\
\hline 1983 & January & Eliminate tax cuts & CBS \\
\hline 1983 & January & Reduced spending & CBS \\
\hline 1983 & January & Cut entitlements & Gallup \\
\hline 1983 & June & Eliminate tax cuts & CBS \\
\hline 1983 & June & Balance budget amendment & Gallup \\
\hline 1983 & June & Cut entitlements & Gallup \\
\hline 1983 & June & Nuclear power & Roper \\
\hline 1983 & September & National health insurance & Roper \\
\hline 1983 & various & Govt reduce income differences between rich and poor & GSS \\
\hline 1983 & various & Govt help poor & GSS \\
\hline 1983 & various & Govt help pay medical bills & GSS \\
\hline 1984 & December & Cut entitlements & Gallup \\
\hline 1984 & February & Balance budget amendment & Gallup \\
\hline 1984 & July & Government size & $\mathrm{ABC}$ \\
\hline 1984 & July & Government size & $\mathrm{ABC}$ \\
\hline
\end{tabular}


Survey Text A13 Continued from previous page

\begin{tabular}{|c|c|c|c|}
\hline Year & Month & Item & Organization \\
\hline 1984 & October & Guaranteed jobs (multi-point scale) & ANES \\
\hline 1984 & October & More spending & ANES \\
\hline 1984 & October & Universal healthcare (ANES- v2) & ANES \\
\hline 1984 & various & Govt reduce income differences between rich and poor & GSS \\
\hline 1984 & various & Govt help poor & GSS \\
\hline 1984 & various & Govt help pay medical bills & GSS \\
\hline 1985 & December & No welfare for ablebodied adults & $\mathrm{ABC}$ \\
\hline 1985 & June & Cut entitlements & Gallup \\
\hline 1985 & June & Lower top tax bracket & Gallup \\
\hline 1985 & November & Taxes vs spending (1985) & CBS \\
\hline 1985 & September & Ban cigarette advertisements & $\mathrm{ABC}$ \\
\hline 1985 & various & Govt responsibility to provide health care for sick & GSS \\
\hline 1985 & various & Govt responsibility to provide jobs for all & GSS \\
\hline 1986 & January & Environment & CBS \\
\hline 1986 & October & Guaranteed jobs (multi-point scale) & ANES \\
\hline 1986 & September & Taxes vs spending (1986) & Time \\
\hline 1986 & various & Govt reduce income differences between rich and poor & GSS \\
\hline 1986 & various & Govt help poor & GSS \\
\hline 1986 & various & Govt help pay medical bills & GSS \\
\hline 1987 & January & Guaranteed jobs (non-likert) & $\mathrm{ABC}$ \\
\hline 1987 & March & Ban cigarette advertisements & Gallup \\
\hline 1987 & May & Balance budget amendment & CBS \\
\hline 1987 & various & Govt reduce income differences between rich and poor & GSS \\
\hline 1987 & various & Govt help poor & GSS \\
\hline 1987 & various & Govt help pay medical bills & GSS \\
\hline 1987 & Various & Govt provide minimum standard of living & Pew \\
\hline 1988 & August & Balance budget amendment & CBS \\
\hline 1988 & August & Layoffs & CBS \\
\hline 1988 & July & Government size & $\mathrm{ABC}$ \\
\hline 1988 & July & Environment & CBS \\
\hline 1988 & July & Ban cigarette advertisements & Gallup \\
\hline 1988 & May & Layoffs & $\mathrm{ABC}$ \\
\hline 1988 & May & Government size & CBS \\
\hline 1988 & May & Govt provide minimum standard of living & Gallup \\
\hline 1988 & November & Spending on health care & ANES Senate \\
\hline 1988 & November & Spending on schools & ANES Senate \\
\hline 1988 & October & Guaranteed jobs (multi-point scale) & ANES \\
\hline 1988 & October & Universal healthcare (ANES- v2) & ANES \\
\hline 1988 & October & Government size & CBS \\
\hline 1988 & various & Govt reduce income differences between rich and poor & GSS \\
\hline 1988 & various & Govt help poor & GSS \\
\hline 1988 & various & Govt help pay medical bills & GSS \\
\hline 1989 & April & Minimum wage (1989) & $\mathrm{ABC}$ \\
\hline 1989 & April & Environment & CBS \\
\hline 1989 & April & Clean Air Act Amendments & Gallup \\
\hline 1989 & August & Capital gains tax cut & $\mathrm{ABC}$ \\
\hline 1989 & February & Capital gains tax cut & $\mathrm{ABC}$ \\
\hline 1989 & January & Government size & CBS \\
\hline 1989 & June & Clean Air Act Amendments & $\mathrm{ABC}$ \\
\hline 1989 & June & Minimum wage (1989) & $\mathrm{ABC}$ \\
\hline 1989 & May & Minimum wage (1989) & Gallup \\
\hline 1989 & October & Capital gains tax cut & Gallup \\
\hline 1989 & various & Govt reduce income differences between rich and poor & GSS \\
\hline 1989 & various & Govt help poor & GSS \\
\hline 1989 & various & Govt help pay medical bills & GSS \\
\hline 1989 & various & Govt responsibility to provide jobs for all & GSS \\
\hline 1989 & various & Govt provide minimum standard of living & Pew \\
\hline 1990 & April & Clean Air Act Amendments & $\mathrm{NBC}$ \\
\hline 1990 & April & Nuclear power & $\mathrm{NBC}$ \\
\hline 1990 & February & Capital gains tax cut & $\mathrm{ABC}$ \\
\hline 1990 & July & Ban cigarette advertisements & Gallup \\
\hline 1990 & March & Nuclear power & $\mathrm{ABC}$ \\
\hline 1990 & March & Clean Air Act Amendments & WashPost \\
\hline 1990 & November & Spending on health care & ANES Senate \\
\hline 1990 & November & Spending on homeless & ANES Senate \\
\hline
\end{tabular}


Survey Text A13 Continued from previous page

\begin{tabular}{|c|c|c|c|}
\hline Year & Month & Item & Organization \\
\hline 1990 & November & Spending on schools & ANES Senate \\
\hline 1990 & October & Guaranteed jobs (multi-point scale) & ANES \\
\hline 1990 & October & National health insurance & CBS \\
\hline 1990 & various & Govt reduce income differences between rich and poor & GSS \\
\hline 1990 & various & Govt help poor & GSS \\
\hline 1990 & various & Govt help pay medical bills & GSS \\
\hline 1990 & various & Govt responsibility to provide health care for sick & GSS \\
\hline 1990 & various & Govt responsibility to provide jobs for all & GSS \\
\hline 1991 & April & Nuclear power & Time \\
\hline 1991 & August & National health insurance & CBS \\
\hline 1991 & December & National health insurance & Time \\
\hline 1991 & July & Universal healthcare (v2) & Gallup \\
\hline 1991 & June & National health insurance & CBS \\
\hline 1991 & October & Family leave & $\mathrm{ABC}$ \\
\hline 1991 & October & Unemployment (1992) & $\mathrm{ABC}$ \\
\hline 1991 & October & Unemployment (1992) & $\mathrm{ABC}$ \\
\hline 1991 & October & Government size & CBS \\
\hline 1991 & October & Ban cigarette advertisements & Gallup \\
\hline 1991 & September & Unemployment (1992) & LATimes \\
\hline 1991 & various & Govt reduce income differences between rich and poor & GSS \\
\hline 1991 & various & Govt help poor & GSS \\
\hline 1991 & various & Govt help pay medical bills & GSS \\
\hline 1991 & various & Govt responsibility to provide jobs for all & GSS \\
\hline 1991 & various & Govt provide minimum standard of living & Pew \\
\hline 1992 & January & National health insurance & CBS \\
\hline 1992 & July & Government size & $\mathrm{ABC}$ \\
\hline 1992 & July & National health insurance & CBS \\
\hline 1992 & June & Balance budget amendment & $\mathrm{ABC}$ \\
\hline 1992 & June & Guaranteed jobs (non-likert) & CBS \\
\hline 1992 & June & Universal healthcare (v2) & CBS \\
\hline 1992 & March & Nuclear power & Time \\
\hline 1992 & May & Environment & CBS \\
\hline 1992 & May & Family leave & Gallup \\
\hline 1992 & November & Spending on health care & ANES Senate \\
\hline 1992 & November & Spending on homeless & ANES Senate \\
\hline 1992 & November & Spending on schools & ANES Senate \\
\hline 1992 & November & Family leave & Gallup \\
\hline 1992 & October & Guaranteed jobs (multi-point scale) & ANES \\
\hline 1992 & October & Universal healthcare (ANES- v2) & ANES \\
\hline 1992 & October & Family leave & CBS \\
\hline 1992 & various & Govt provide minimum standard of living & Pew \\
\hline 1993 & January & Family leave & $\mathrm{ABC}$ \\
\hline 1993 & January & Family leave & CBS \\
\hline 1993 & January & National health insurance & CBS \\
\hline 1993 & June & Government size & LATimes \\
\hline 1993 & September & Universal healthcare (v2) & CBS \\
\hline 1993 & September & Universal healthcare (v2) & Gallup \\
\hline 1993 & various & Govt reduce income differences between rich and poor & GSS \\
\hline 1993 & various & Govt help poor & GSS \\
\hline 1993 & various & Govt help pay medical bills & GSS \\
\hline 1994 & December & Welfare - 5 year max & Gallup \\
\hline 1994 & February & Balance budget amendment & $\mathrm{ABC}$ \\
\hline 1994 & January & Balance budget amendment & Gallup \\
\hline 1994 & July & Universal healthcare (v2) & CBS \\
\hline 1994 & March & Ban cigarette advertisements & Gallup \\
\hline 1994 & November & Balance budget amendment & Gallup \\
\hline 1994 & October & Guaranteed jobs (multi-point scale) & ANES \\
\hline 1994 & October & Universal healthcare (ANES- v2) & ANES \\
\hline 1994 & various & Govt reduce income differences between rich and poor & GSS \\
\hline 1994 & various & Govt help poor & GSS \\
\hline 1994 & various & Govt help pay medical bills & GSS \\
\hline 1995 & December & Universal healthcare for poor & CBS \\
\hline 1995 & December & National health insurance & NYTimes \\
\hline 1995 & December & Scale back Medicaid & NYTimes \\
\hline 1995 & December & Scale back welfare & NYTimes \\
\hline
\end{tabular}


Survey Text A13 Continued from previous page

\begin{tabular}{|c|c|c|c|}
\hline Year & Month & Item & Organization \\
\hline 1995 & February & Minimum wage (1995) & Gallup \\
\hline 1995 & January & Balance budget amendment & $\mathrm{ABC}$ \\
\hline 1995 & January & Minimum wage (1995) & $\mathrm{ABC}$ \\
\hline 1995 & January & Government size & LATimes \\
\hline 1995 & January & Minimum wage (1995) & LATimes \\
\hline 1995 & January & National health insurance & NA \\
\hline 1995 & October & Government size & LATimes \\
\hline 1995 & September & Government size & LATimes \\
\hline 1996 & April & Minimum wage (1995) & $\mathrm{AP}$ \\
\hline 1996 & April & Minimum wage (1995) & CBS \\
\hline 1996 & April & Balance budget amendment & Gallup \\
\hline 1996 & April & Government size & LATimes \\
\hline 1996 & April & Minimum wage $(1995)$ & LATimes \\
\hline 1996 & August & Balance budget amendment & $\mathrm{ABC}$ \\
\hline 1996 & August & Government size & $\mathrm{ABC}$ \\
\hline 1996 & August & Welfare - 5 year max & $\mathrm{ABC}$ \\
\hline 1996 & August & Welfare reform & $\mathrm{ABC}$ \\
\hline 1996 & February & Government size & $\mathrm{CBS}$ \\
\hline 1996 & February & Guaranteed jobs (likert) & CBS \\
\hline 1996 & February & Universal healthcare (v2) & CBS \\
\hline 1996 & June & Welfare - 5 year max & $\mathrm{AP}$ \\
\hline 1996 & June & Environment & CBS \\
\hline 1996 & May & Minimum wage (1995) & Gallup \\
\hline 1996 & May & Minimum wage (1995) & Time \\
\hline 1996 & October & Environmental protection & ANES \\
\hline 1996 & October & Guaranteed jobs (multi-point scale) & ANES \\
\hline 1996 & October & Universal healthcare (ANES- v2) & ANES \\
\hline 1996 & October & Welfare - 5 year max & CBS \\
\hline 1996 & various & Govt reduce income differences between rich and poor & GSS \\
\hline 1996 & various & Govt help poor & GSS \\
\hline 1996 & various & Govt help pay medical bills & GSS \\
\hline 1996 & various & Govt responsibility to provide health care for sick & GSS \\
\hline 1996 & various & Govt responsibility to provide jobs for all & GSS \\
\hline 1997 & February & Balance budget amendment & $\mathrm{CBS}$ \\
\hline 1997 & February & Balance budget amendment & Time \\
\hline 1997 & January & Welfare - 5 year $\max$ & AP \\
\hline 1997 & January & Welfare reform & CBS \\
\hline 1997 & January & Balance budget amendment & Gallup \\
\hline 1997 & June & Ban cigarette advertisements & $\mathrm{ABC}$ \\
\hline 1997 & June & Medicare reform & Gallup \\
\hline 1997 & June & Medicare reform & Pew \\
\hline 1997 & March & Balance budget amendment & $\mathrm{ABC}$ \\
\hline 1997 & November & Environment & CBS \\
\hline 1997 & September & Ban cigarette advertisements & Gallup \\
\hline 1997 & September & Medicare reform & LATimes \\
\hline 1997 & various & Govt provide minimum standard of living & Pew \\
\hline 1998 & December & Privatize social security (v2) & Gallup \\
\hline 1998 & December & National health insurance (v2) & Kaiser \\
\hline 1998 & July & Privatize social security (v2) & Gallup \\
\hline 1998 & October & Environmental protection & ANES \\
\hline 1998 & October & Guaranteed jobs (multi-point scale) & ANES \\
\hline 1998 & various & Govt reduce income differences between rich and poor & GSS \\
\hline 1998 & various & Govt help poor & GSS \\
\hline 1998 & various & Govt help pay medical bills & GSS \\
\hline 1998 & various & Govt responsibility to provide jobs for all & GSS \\
\hline 1999 & April & Minimum wage (2000) & Gallup \\
\hline 1999 & December & Health care for children & Kaiser \\
\hline 1999 & June & Government size & WashPost \\
\hline 1999 & October & National health insurance (v2) & Kaiser \\
\hline 1999 & October & Minimum wage (2000) & Pew \\
\hline 1999 & September & Government size & CBS \\
\hline 1999 & September & Guaranteed jobs (non-likert) & CBS \\
\hline 1999 & various & Flat tax & NAES \\
\hline 1999 & various & Reduce inequality & NAES \\
\hline 1999 & various & Taxes on rich & NAES \\
\hline
\end{tabular}


Survey Text A13 Continued from previous page

\begin{tabular}{|c|c|c|c|}
\hline Year & Month & Item & Organization \\
\hline 1999 & various & Universal healthcare & NAES \\
\hline 1999 & various & Govt provide minimum standard of living & Pew \\
\hline 2000 & December & Bush tax cuts (2001) & CBS \\
\hline 2000 & December & Health care for children & Kaiser \\
\hline 2000 & December & National health insurance (v2) & Kaiser \\
\hline 2000 & January & Privatize social security (v2) & Gallup \\
\hline 2000 & January & Universal healthcare (v2) & Gallup \\
\hline 2000 & July & Government size & $\mathrm{ABC}$ \\
\hline 2000 & July & Universal healthcare (v2) & CBS \\
\hline 2000 & July & Health care for children & Kaiser \\
\hline 2000 & July & National health insurance (v2) & Kaiser \\
\hline 2000 & June & Privatize social security (v2) & Gallup \\
\hline 2000 & March & Government size & $\mathrm{ABC}$ \\
\hline 2000 & May & Privatize social security (v3) & $\mathrm{ABC}$ \\
\hline 2000 & October & Government size & $\mathrm{ABC}$ \\
\hline 2000 & October & Privatize social security (v3) & $\mathrm{ABC}$ \\
\hline 2000 & October & Bush tax cuts (2001) & ANES \\
\hline 2000 & October & Environmental protection & ANES \\
\hline 2000 & October & Guaranteed jobs (multi-point scale) & ANES \\
\hline 2000 & October & Universal healthcare (ANES- v2) & ANES \\
\hline 2000 & October & Minimum wage (2000) & Gallup \\
\hline 2000 & October & Government size & WashPost \\
\hline 2000 & September & Government size & $\mathrm{ABC}$ \\
\hline 2000 & September & Universal healthcare (v2) & Gallup \\
\hline 2000 & September & Government size & LATimes \\
\hline 2000 & various & Govt reduce income differences between rich and poor & GSS \\
\hline 2000 & various & Govt help poor & GSS \\
\hline 2000 & various & Govt help pay medical bills & GSS \\
\hline 2000 & various & Estate tax & NAES \\
\hline 2000 & various & Flat tax & NAES \\
\hline 2000 & various & Health care for children & NAES \\
\hline 2000 & various & Privatize social security & NAES \\
\hline 2000 & various & Reduce inequality & NAES \\
\hline 2000 & various & Taxes on rich & NAES \\
\hline 2000 & various & Universal healthcare & NAES \\
\hline 2001 & April & Drilling in Arctic & $\mathrm{ABC}$ \\
\hline 2001 & April & Nuclear power & $\mathrm{ABC}$ \\
\hline 2001 & April & Privatize social security (v3) & $\mathrm{ABC}$ \\
\hline 2001 & April & Bush tax cuts (2001) & CBS \\
\hline 2001 & April & Bush tax cuts (2001) & CBS \\
\hline 2001 & April & Drilling in Arctic & CBS \\
\hline 2001 & April & Bush tax cuts (2001) & Pew \\
\hline 2001 & August & Bush tax cuts (2001) & CBS \\
\hline 2001 & August & Drilling in Arctic & CBS \\
\hline 2001 & February & Bush tax cuts (2001) & CBS \\
\hline 2001 & February & Drilling in Arctic & CBS \\
\hline 2001 & February & Bush tax cuts (2001) & Pew \\
\hline 2001 & January & Drilling in Arctic & $\mathrm{ABC}$ \\
\hline 2001 & January & Government size & CBS \\
\hline 2001 & June & Nuclear power & $\mathrm{ABC}$ \\
\hline 2001 & June & Environment & $\mathrm{CBS}$ \\
\hline 2001 & March & Bush tax cuts (2001) & $\mathrm{ABC}$ \\
\hline 2001 & March & Privatize social security (v3) & $\mathrm{ABC}$ \\
\hline 2001 & March & Bush tax cuts (2001) & CBS \\
\hline 2001 & March & Drilling in Arctic & CBS \\
\hline 2001 & March & Estate tax & CBS \\
\hline 2001 & March & Estate tax & CBS \\
\hline 2001 & May & Drilling in Arctic & Gallup \\
\hline 2001 & May & Privatize social security (v2) & Gallup \\
\hline 2001 & November & Drilling in Arctic & Gallup \\
\hline 2001 & November & Privatize social security (v2) & Gallup \\
\hline 2001 & November & Government size & LATimes \\
\hline 2001 & October & Government size & CBS \\
\hline 2002 & August & Government size & WashPost \\
\hline 2002 & December & Privatize social security (v2) & Gallup \\
\hline
\end{tabular}


Survey Text A13 Continued from previous page

\begin{tabular}{|c|c|c|c|}
\hline Year & Month & Item & Organization \\
\hline 2002 & January & Drilling in Arctic & $\mathrm{ABC}$ \\
\hline 2002 & January & Government size & $\mathrm{ABC}$ \\
\hline 2002 & January & Environment & CBS \\
\hline 2002 & January & Government size & CBS \\
\hline 2002 & January & Drilling in Arctic & Gallup \\
\hline 2002 & January & Privatize social security (v2) & Gallup \\
\hline 2002 & July & Government size & $\mathrm{ABC}$ \\
\hline 2002 & July & Privatize social security (v3) & $\mathrm{ABC}$ \\
\hline 2002 & November & Environment & CBS \\
\hline 2002 & November & Estate tax & Gallup \\
\hline 2002 & November & Privatize social security (v2) & Gallup \\
\hline 2002 & October & Bush tax cuts $(2001)$ & ANES \\
\hline 2002 & October & Estate tax & ANES \\
\hline 2002 & October & Guaranteed jobs (non-likert) & ANES \\
\hline 2002 & various & Govt reduce income differences between rich and poor & GSS \\
\hline 2002 & various & Govt help poor & GSS \\
\hline 2002 & various & Govt help pay medical bills & GSS \\
\hline 2002 & various & Govt provide minimum standard of living & Pew \\
\hline 2003 & April & Bush tax (2003) & Gallup \\
\hline 2003 & August & Bush tax (2003) & Pew \\
\hline 2003 & July & Government size & CBS \\
\hline 2003 & May & Bush tax (2003) & Gallup \\
\hline 2003 & May & Bush tax (2003) & Pew \\
\hline 2003 & November & Government size & CBS \\
\hline 2003 & October & Privatize social security (v2) & Gallup \\
\hline 2003 & various & Privatize social security & NAES \\
\hline 2003 & various & Reduce inequality & NAES \\
\hline 2003 & various & Universal healthcare & NAES \\
\hline 2003 & various & Govt provide minimum standard of living & Pew \\
\hline 2004 & December & Privatize social security (v3) & $\mathrm{ABC}$ \\
\hline 2004 & December & Minimum wage & Pew \\
\hline 2004 & June & Government size & $\mathrm{ABC}$ \\
\hline 2004 & October & Guaranteed jobs (multi-point scale) & ANES \\
\hline 2004 & October & Universal healthcare (ANES- v2) & ANES \\
\hline 2004 & various & Govt reduce income differences between rich and poor & GSS \\
\hline 2004 & various & Govt help poor & GSS \\
\hline 2004 & various & Govt help pay medical bills & GSS \\
\hline 2004 & various & Estate tax & NAES \\
\hline 2004 & various & Health care for children & NAES \\
\hline 2004 & various & Privatize social security & NAES \\
\hline 2004 & various & Reduce inequality & NAES \\
\hline 2004 & various & Universal healthcare & NAES \\
\hline 2005 & April & Privatize social security (v3) & $\mathrm{ABC}$ \\
\hline 2005 & April & Privatize social security (v2) & Gallup \\
\hline 2005 & January & Privatize social security (v3) & $\mathrm{ABC}$ \\
\hline 2005 & January & Government size & LATimes \\
\hline 2005 & July & Spending on the poor & Pew \\
\hline 2005 & July & Universal healthcare (v2) & Pew \\
\hline 2005 & June & Drilling in Arctic & $\mathrm{ABC}$ \\
\hline 2005 & June & Nuclear power & $\mathrm{ABC}$ \\
\hline 2005 & June & Privatize social security (v3) & $\mathrm{ABC}$ \\
\hline 2005 & March & Privatize social security (v3) & $\mathrm{ABC}$ \\
\hline 2005 & March & Privatize social security (v2) & Gallup \\
\hline 2005 & March & Drilling in Arctic & Pew \\
\hline 2005 & March & Drilling in Arctic & Pew \\
\hline 2005 & September & Drilling in Arctic & Pew \\
\hline 2006 & February & Federal spending on renewable energy (2006) & Pew \\
\hline 2006 & January & Universal healthcare (v2) & CBS \\
\hline 2006 & January & Drilling in Arctic & Pew \\
\hline 2006 & July & Minimum wage & CBS \\
\hline 2006 & June & Privatize social security (v2) & Gallup \\
\hline 2006 & March & Minimum wage & Pew \\
\hline 2006 & May & Drilling in Arctic & CBS \\
\hline 2006 & May & Drilling in Arctic & Pew \\
\hline 2006 & October & Environment & CBS \\
\hline
\end{tabular}


Survey Text A13 Continued from previous page

\begin{tabular}{|c|c|c|c|}
\hline Year & Month & Item & Organization \\
\hline 2006 & October & Health care for children & CBS \\
\hline 2006 & September & Expand Medicaid for children & $\mathrm{ABC}$ \\
\hline 2006 & September & Health care for children & $\mathrm{ABC}$ \\
\hline 2006 & various & Govt reduce income differences between rich and poor & GSS \\
\hline 2006 & various & Govt help poor & GSS \\
\hline 2006 & various & Govt help pay medical bills & GSS \\
\hline 2006 & various & Govt responsibility to provide health care for sick & GSS \\
\hline 2006 & various & Govt responsibility to provide jobs for all & GSS \\
\hline 2007 & April & Drilling in Arctic & $\mathrm{ABC}$ \\
\hline 2007 & April & Drilling in Arctic & CBS \\
\hline 2007 & April & Environment & CBS \\
\hline 2007 & February & Expand Medicaid for children & CBS \\
\hline 2007 & February & Health care for children & CBS \\
\hline 2007 & January & Minimum wage & $\mathrm{ABC}$ \\
\hline 2007 & January & Minimum wage & Pew \\
\hline 2007 & November & Government size & Pew \\
\hline 2007 & October & Government size & $\mathrm{ABC}$ \\
\hline 2007 & September & Expand Medicaid for children & $\mathrm{ABC}$ \\
\hline 2007 & September & Health care for children & $\mathrm{ABC}$ \\
\hline 2007 & various & Govt provide minimum standard of living & Pew \\
\hline 2008 & April & Raise taxes on wealthy & CBS \\
\hline 2008 & December & Auto bailout & $\mathrm{ABC}$ \\
\hline 2008 & December & Expand Medicaid for children & $\mathrm{ABC}$ \\
\hline 2008 & December & Health care for children & $\mathrm{ABC}$ \\
\hline 2008 & December & Auto bailout & CBS \\
\hline 2008 & December & Auto bailout & Gallup \\
\hline 2008 & December & Auto bailout & Gallup \\
\hline 2008 & December & Auto bailout & Pew \\
\hline 2008 & February & Drilling in Arctic & Pew \\
\hline 2008 & February & Federal spending on renewable energy (2008) & Pew \\
\hline 2008 & July & Clean energy bill & $\mathrm{ABC}$ \\
\hline 2008 & July & Nuclear power & $\mathrm{ABC}$ \\
\hline 2008 & June & Federal spending on renewable energy (2008) & $\mathrm{ABC}$ \\
\hline 2008 & June & Government size & $\mathrm{ABC}$ \\
\hline 2008 & June & Drilling in Arctic & Pew \\
\hline 2008 & March & Government size & CBS \\
\hline 2008 & November & Auto bailout & Gallup \\
\hline 2008 & October & Guaranteed jobs (multi-point scale) & ANES \\
\hline 2008 & October & Government size & Pew \\
\hline 2008 & September & Drilling in Arctic & Pew \\
\hline 2008 & September & Federal spending on renewable energy (2008) & Pew \\
\hline 2008 & various & Universal healthcare (ANES- v2) & ANES \\
\hline 2008 & various & Govt reduce income differences between rich and poor & GSS \\
\hline 2008 & various & Govt help poor & GSS \\
\hline 2008 & various & Govt help pay medical bills & GSS \\
\hline 2009 & April & Limit GHG emissions (v1) & $\mathrm{ABC}$ \\
\hline 2009 & April & Government size & $\mathrm{CBS}$ \\
\hline 2009 & April & Federal spending on renewable energy (2009) & Pew \\
\hline 2009 & August & Nuclear power & $\mathrm{ABC}$ \\
\hline 2009 & December & Affordable Care Act (v1) & $\mathrm{ABC}$ \\
\hline 2009 & December & Clean energy bill & $\mathrm{ABC}$ \\
\hline 2009 & December & Clean energy bill & $\mathrm{ABC}$ \\
\hline 2009 & December & Limit GHG emissions (v1) & $\mathrm{ABC}$ \\
\hline 2009 & February & Recovery Act & $\mathrm{ABC}$ \\
\hline 2009 & February & Recovery Act & $\mathrm{CBS}$ \\
\hline 2009 & February & Recovery Act & Pew \\
\hline 2009 & July & Universal healthcare (v2) & CBS \\
\hline 2009 & July & Clean energy bill & Pew \\
\hline 2009 & July & Clean energy bill & Pew \\
\hline 2009 & June & Clean energy bill & $\mathrm{ABC}$ \\
\hline 2009 & June & Government size & $\mathrm{ABC}$ \\
\hline 2009 & June & Limit GHG emissions (v1) & $\mathrm{ABC}$ \\
\hline 2009 & June & Universal healthcare (v2) & CBS \\
\hline 2009 & June & Recovery Act & Pew \\
\hline 2009 & March & Universal healthcare (v2) & CBS \\
\hline
\end{tabular}


Survey Text A13 Continued from previous page

\begin{tabular}{|c|c|c|c|}
\hline Year & Month & Item & Organization \\
\hline 2009 & March & Government size & Pew \\
\hline 2009 & March & Recovery Act & Pew \\
\hline 2009 & May & Expand Medicaid for children & CBS \\
\hline 2009 & May & Health care for children & CBS \\
\hline 2009 & May & Nuclear power & Pew \\
\hline 2009 & November & Affordable Care Act (v1) & $\mathrm{ABC}$ \\
\hline 2009 & November & Clean energy bill & $\mathrm{ABC}$ \\
\hline 2009 & November & Affordable Care Act (v2) & CBS \\
\hline 2009 & October & Affordable Care Act (v1) & ANES \\
\hline 2009 & October & Clean energy bill & ANES \\
\hline 2009 & October & Expand Medicaid for children & ANES \\
\hline 2009 & October & Federal spending on renewable energy (2009) & ANES \\
\hline 2009 & October & Health care for children & ANES \\
\hline 2009 & October & Clean energy bill & Pew \\
\hline 2009 & October & Recovery Act & Pew \\
\hline 2009 & September & Universal healthcare (v2) & CBS \\
\hline 2009 & September & Government size & Pew \\
\hline 2009 & various & Govt provide minimum standard of living & Pew \\
\hline 2010 & April & Financial reform bill & $\mathrm{ABC}$ \\
\hline 2010 & April & Government size & $\mathrm{CBS}$ \\
\hline 2010 & April & Government size & Pew \\
\hline 2010 & August & Expand oil drilling & Pew \\
\hline 2010 & August & Government size & Pew \\
\hline 2010 & August & Limit GHG emissions (v2) & Pew \\
\hline 2010 & February & Financial reform bill & CBS \\
\hline 2010 & February & Government size & CBS \\
\hline 2010 & February & Raise taxes on wealthy & CBS \\
\hline 2010 & February & Clean energy bill & Pew \\
\hline 2010 & February & Federal spending on renewable energy (2010) & Pew \\
\hline 2010 & February & Government size & Pew \\
\hline 2010 & January & Affordable Care Act (v1) & $\mathrm{ABC}$ \\
\hline 2010 & January & Government size & $\mathrm{ABC}$ \\
\hline 2010 & July & Affordable Care Act (v2) & CBS \\
\hline 2010 & July & Financial reform bill & $\mathrm{CBS}$ \\
\hline 2010 & June & Financial reform bill & $\mathrm{ABC}$ \\
\hline 2010 & June & Federal spending on renewable energy (2010) & Pew \\
\hline 2010 & June & Limit GHG emissions (v2) & Pew \\
\hline 2010 & March & Affordable Care Act (v2) & CBS \\
\hline 2010 & May & Financial reform bill & CBS \\
\hline 2010 & May & Federal spending on renewable energy (2010) & Pew \\
\hline 2010 & October & Government size & $\mathrm{ABC}$ \\
\hline 2010 & October & Government size & CBS \\
\hline 2010 & October & Raise taxes on wealthy & CBS \\
\hline 2010 & October & Federal spending on renewable energy (2010) & Pew \\
\hline 2010 & September & Government size & CBS \\
\hline 2010 & September & Raise taxes on wealthy & CBS \\
\hline 2010 & various & Govt reduce income differences between rich and poor & GSS \\
\hline 2010 & various & Govt help poor & GSS \\
\hline 2010 & various & Govt help pay medical bills & GSS \\
\hline 2011 & April & Government size & CBS \\
\hline 2011 & April & Raise taxes on wealthy & CBS \\
\hline 2011 & April & Raise taxes on wealthy & Gallup \\
\hline 2011 & February & Light bulb law & Gallup \\
\hline 2011 & January & Affordable Care Act (v1) & $\mathrm{ABC}$ \\
\hline 2011 & January & Expand oil drilling & Gallup \\
\hline 2011 & June & Affordable Care Act (v2) & CNN \\
\hline 2011 & March & Affordable Care Act (v2) & $\mathrm{CNN}$ \\
\hline 2011 & March & Federal spending on renewable energy (2011) & Pew \\
\hline 2011 & October & Raise taxes on wealthy & $\mathrm{CNN}$ \\
\hline 2011 & October & Government size & Pew \\
\hline 2011 & October & Minimum wage (10 dollars) & PRRI \\
\hline 2011 & September & Government size & $\mathrm{ABC}$ \\
\hline 2011 & September & Government size & Pew \\
\hline 2012 & April & Affordable Care Act (v1) & $\mathrm{ABC}$ \\
\hline 2012 & August & Government size & $\mathrm{ABC}$ \\
\hline
\end{tabular}


Survey Text A13 Continued from previous page

\begin{tabular}{|c|c|c|c|}
\hline Year & Month & Item & Organization \\
\hline 2012 & August & Government size & CBS \\
\hline 2012 & August & Raise taxes on wealthy & Kaiser \\
\hline 2012 & December & Raise taxes on wealthy & CBS \\
\hline 2012 & January & Government size & Pew \\
\hline 2012 & July & Affordable Care Act (v1) & $\mathrm{ABC}$ \\
\hline 2012 & March & Affordable Care Act (v1) & $\mathrm{ABC}$ \\
\hline 2012 & March & Affordable Care Act (v2) & $\mathrm{CNN}$ \\
\hline 2012 & March & Federal spending on renewable energy (2012) & Pew \\
\hline 2012 & November & Affordable Care Act (v2) & CNN \\
\hline 2012 & October & Guaranteed jobs (multi-point scale) & ANES \\
\hline 2012 & October & Universal healthcare (ANES- v2) & ANES \\
\hline 2012 & September & Government size & Pew \\
\hline 2012 & various & Govt provide minimum standard of living & pew \\
\hline 2013 & April & Keystone pipeline & Gallup \\
\hline 2013 & December & Affordable Care Act (v1) & $\mathrm{ABC}$ \\
\hline 2013 & December & Affordable Care Act (v2) & CNN \\
\hline 2013 & December & Minimum wage (10 dollars) & ReasonRupe \\
\hline 2013 & July & Affordable Care Act (v1) & $\mathrm{ABC}$ \\
\hline 2013 & May & Affordable Care Act (v2) & $\mathrm{CNN}$ \\
\hline 2013 & November & Affordable Care Act (v1) & $\mathrm{ABC}$ \\
\hline 2013 & November & Affordable Care Act (v2) & $\mathrm{CNN}$ \\
\hline 2013 & October & Affordable Care Act (v1) & $\mathrm{ABC}$ \\
\hline 2013 & October & Affordable Care Act (v2) & $\mathrm{CNN}$ \\
\hline 2013 & September & Affordable Care Act (v1) & $\mathrm{ABC}$ \\
\hline 2013 & September & Affordable Care Act (v2) & $\mathrm{CNN}$ \\
\hline 2013 & September & Affordable Care Act (v2) & Pew \\
\hline 2013 & September & Federal spending on renewable energy (2013) & Pew \\
\hline 2013 & September & Government size & Pew \\
\hline 2013 & September & Keystone pipeline & Pew \\
\hline 2013 & September & Limit GHG emissions (v2) & Pew \\
\hline 2014 & April & Affordable Care Act (v1) & $\mathrm{ABC}$ \\
\hline 2014 & February & Minimum wage (10 dollars) & CBS \\
\hline 2014 & January & Affordable Care Act (v1) & $\mathrm{ABC}$ \\
\hline 2014 & January & Minimum wage (10 dollars) & CBS \\
\hline 2014 & January & Minimum wage (10 dollars) & Gallup \\
\hline 2014 & July & Affordable Care Act (v2) & $\mathrm{CNN}$ \\
\hline 2014 & June & Limit GHG emissions (v1) & $\mathrm{ABC}$ \\
\hline 2014 & March & Keystone pipeline & $\mathrm{ABC}$ \\
\hline 2014 & March & Affordable Care Act (v2) & $\mathrm{CNN}$ \\
\hline 2014 & March & Affordable Care Act (v2) & Pew \\
\hline 2014 & March & Keystone pipeline & Pew \\
\hline 2014 & March & Universal healthcare (v2) & Pew \\
\hline 2014 & May & Keystone pipeline & CBS \\
\hline 2014 & November & Keystone pipeline & Pew \\
\hline 2014 & November & Limit GHG emissions (v2) & Pew \\
\hline 2014 & September & Affordable Care Act (v1) & $\mathrm{ABC}$ \\
\hline 2014 & September & Affordable Care Act (v2) & Pew \\
\hline 2014 & September & Government size & Pew \\
\hline
\end{tabular}




\section{References for Appendix}

Adcock, Robert, and David Collier. 2001. "Measurement Validity: A Shared Standard for Qualitative and Quantitative Research." American Political Science Review 95 (3): 529 546.

Ansolabehere, Stephen, James M. Snyder Jr., and Charles Stewart III. 2001. "Candidate Positioning in U.S. House Elections." American Journal of Political Science 45 (1): 136-159.

Bailey, Michael. 2001. "Ideal Point Estimation with a Small Number of Votes: A RandomEffects Approach." Political Analysis 9, no. 3 (June): 192-210.

Berry, William D., Evan J. Ringquist, Richard C. Fording, and Russell L. Hanson. 1998. "Measuring Citizen and Government Ideology in the American States, 1960-93." American Journal of Political Science 42 (1): 327-348.

- 2015. "Assessing the Validity of Enns and Koch's Measure of State Policy Mood." State Politics \& Policy Quarterly 15 (4): 425-435.

Canes-Wrone, Brandice, David W. Brady, and John F. Cogan. 2002. "Out of Step, Out of Office: Electoral Accountability and House Members' Voting." American Political Science Review 96 (1): 127-140.

Carsey, Thomas M, and Jeffrey J Harden. 2010. "New Measures of Partisanship, Ideology, and Policy Mood in the American States." State Politics $\&$ Policy Quarterly 10 (2): $136-156$.

Caughey, Devin, and Christopher Warshaw. 2015. "Dynamic Estimation of Latent Opinion Using a Hierarchical Group-Level IRT Model." Political Analysis 23 (2): 197-211.

—. 2016. "The Dynamics of State Policy Liberalism, 1936-2014." American Journal of Political Science 60 (4): 899-913.

De Boef, Suzanna, and Luke Keele. 2008. "Taking Time Seriously." American Journal of Political Science 52 (1): 184-200.

Dunham, James, Devin Caughey, and Christopher Warshaw. 2016. dgo: Dynamic Estimation of Group-Level Opinion. $R$ package version 0.2.3. https://jamesdunham.github.io/ dgo/.

Enns, Peter K, and Julianna Koch. 2013. "Public Opinion in the U.S. States: 1956 to 2010." State Politics and Policy Quarterly 13 (3): 349-372.

. 2015. "State Policy Mood: The Importance of Over-time Dynamics." State Politics 6 Policy Quarterly 15 (4): 436-446.

Erikson, Robert S., Gerald C. Wright, and John P. McIver. 1993. Statehouse Democracy: Public Opinion and Policy in the American States. New York: Cambridge University Press. 
Erikson, Robert S., Gerald C. Wright, and John P. McIver. 2006. "Public opinion in the states: A quarter century of change and stability." Public opinion in state politics 229:238.

2. 2007. "Measuring the Public's Ideological Preferences in the 50 states: Survey Responses versus Roll Call Data." State Politics 83 Policy Quarterly 7 (2): 141-151.

Fiorina, Morris P., and Samuel J. Abrams. 2008. "Political Polarization in the American Public." Annual Review of Political Science 11 (1): 563-588.

Ghitza, Yair, and Andrew Gelman. 2013. "Deep Interactions with MRP: Election Turnout and Voting Patterns Among Small Electoral Subgroups." American Journal of Political Science 57 (3): 762-776.

Kastellec, Jonathan P., Jeffrey R. Lax, Michael Malecki, and Justin H. Phillips. 2015. "Polarizing the Electoral Connection: Partisan Representation in Supreme Court Confirmation Politics." The Journal of Politics 77 (3): 787-804.

Kernell, Georgia. 2009. "Giving Order to Districts: Estimating Voter Distributions with National Election Returns." Political Analysis 17 (3): 215-235.

Lax, Jeffrey R., and Justin H. Phillips. 2012. "The Democratic Deficit in the States." American Journal of Political Science 56 (1): 148-166.

Levendusky, Matthew S., Jeremy C. Pope, and Simon D. Jackman. 2008. "Measuring DistrictLevel Partisanship with Implications for the Analysis of US Elections." Journal of Politics 70 (3): 736-753.

Lewis, Jeffrey B. 2001. "Estimating Voter Preference Distributions from Individual-Level Voting Data." Political Analysis 9 (3): 275-297.

McGann, Anthony J. 2014. "Estimating the Political Center from Aggregate Data: An Item Response Theory Alternative to the Stimson Dyad Ratios Algorithm." Political Analysis 22 (1): $115-129$.

Mislevy, Robert J. 1983. "Item Response Models for Grouped Data." Journal of Educational Statistics 8 (4): 271-288.

Pacheco, Julianna. 2014. "Measuring and Evaluating Changes in State Opinion Across Eight Issues." American Politics Research 42 (6): 986-1009.

Park, David K., Andrew Gelman, and Joseph Bafumi. 2004. "Bayesian Multilevel Estimation with Poststratification: State-Level Estimates from National Polls." Political Analysis 12 (4): $375-385$.

Ruggles, Steven, J. Trent Alexander, Katie Genadek, Ronald Goeken, Matthew B. Schroeder, and Matthew Sobek. 2010. Integrated Public Use Microdata Series: Version 5.0 [Machinereadable database]. Minneapolis: University of Minnesota.

Shor, Boris, and Nolan McCarty. 2011. "The Ideological Mapping of American Legislatures." American Political Science Review 105 (3): 530-51. 
Stimson, James A. 1991. Public Opinion in America: Moods, Cycles, and Swings. Boulder, CO: Westview.

Tanner, Martin A. 1996. Tools for Statistical Inference Methods for the Exploration of Posterior Distributions and Likelihood Functions. 3rd ed. New York: Springer.

Tausanovitch, Chris, and Christopher Warshaw. 2013. "Measuring Constituent Policy Preferences in Congress, State Legislatures and Cities." Journal of Politics 75 (2): 330342.

Treier, Shawn, and Simon Jackman. 2008. "Democracy as a Latent Variable." American Journal of Political Science 52 (1): 201-217. 